\title{
National Register of Historic Places Eligibility Testing of Site 41LE326 Lee County, Texas
}

\author{
Andrea Stahman \\ Candace Wallace \\ Linda Ellis \\ Chris Heiligenstein
}

Follow this and additional works at: https://scholarworks.sfasu.edu/ita

Part of the American Material Culture Commons, Archaeological Anthropology Commons, Environmental Studies Commons, Other American Studies Commons, Other Arts and Humanities Commons, Other History of Art, Architecture, and Archaeology Commons, and the United States History Commons

Tell us how this article helped you.

This Article is brought to you for free and open access by the Center for Regional Heritage Research at SFA ScholarWorks. It has been accepted for inclusion in Index of Texas Archaeology: Open Access Gray Literature from the Lone Star State by an authorized editor of SFA ScholarWorks. For more information, please contact cdsscholarworks@sfasu.edu. 


\section{National Register of Historic Places Eligibility Testing of Site 41LE326 Lee County, Texas}

\section{Licensing Statement}

This is a work for hire produced for the Texas Department of Transportation (TxDOT), which owns all rights, title, and interest in and to all data and other information developed for this project under its contract with the report producer. The report may be cited and brief passages from this publication may be reproduced without permission provided that credit is given to TxDOT and the firm that produced it. Permission to reprint an entire chapter, section, figures or tables must be obtained in advance from the Supervisor of the Archeological Studies Branch, Environmental Affairs Division, Texas Department of Transportation, 125 East 11th Street, Austin, Texas, 78701. 
Document No. 100054

PBS\&J Job Nos. 044175900 and 100013236

\title{
National Register of Historic Places Eligibility Testing OF Site 41LE326 Lee County, TeXas
}

\author{
Texas Antiquities Permit No. 4439 \\ WORK AUTHORIZATION NO. 57906SA004 \\ CSJ No. 0211-03-032
}

\author{
Prepared for: \\ Texas Department of Transportation \\ Environmental Affairs Division \\ 118 East Riverside Drive \\ Austin, Texas 78704 \\ Prepared by: \\ PBS\&J \\ 6504 Bridge Point Parkway \\ Suite 200 \\ Austin, Texas 78730 \\ Principal Investigator: \\ Michael A. Nash, M.A. \\ Report Authors: \\ Andrea Stahman, M.A. \\ Candace Wallace, B.A. \\ Linda Ellis, M.A. \\ Chris Heiligenstein, B.A.
}

August 2010 
Copyright (C) 2010

Texas Department of Transportation (TxDOT)

This is a work for hire produced for the Texas Department of Transportation (TxDOT), which owns all rights, title, and interest in and to all data and other information developed for this project under Contract 57906SA004. Brief passages from this publication may be reproduced without permission, provided that credit is given to TxDOT and PBS\&J. Permission to reprint an entire chapter, section, figures or tables must be obtained in advance from the Supervisor of the Archeological Studies Program, Environmental Affairs Division, Texas Department of Transportation, 125 East 11th Street, Austin, Texas, 78701. Copies of this publication have been deposited with the Texas State Library in compliance with the State Depository Requirement.

Printed by Ginny’s Printing

Austin, Texas

published by:

Texas Department of Transportation

Environmental Affairs Division

Archeological Studies Program

Scott Pletka, Ph.D., Supervisor

Archeological Studies Program Report No. 126

A. McGraw, Series Editor

and

PBS\&J

6504 Bridge Point Parkway

Suite 200

Austin, Texas 78730

Document No. 100054

$100013236 / 100054$ 


\section{Contents}

Page

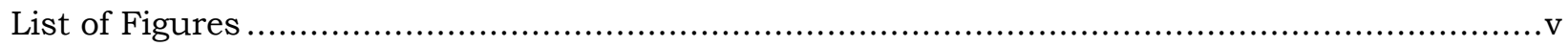

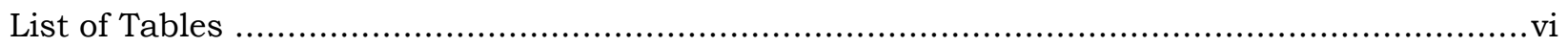

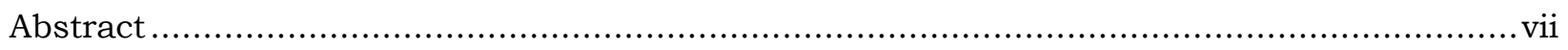

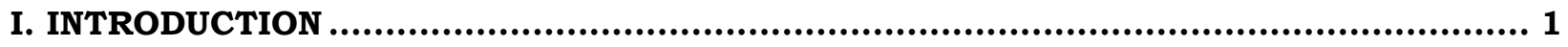

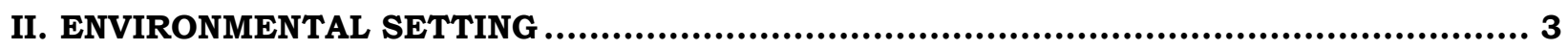

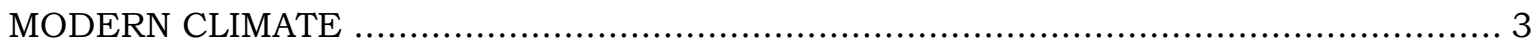

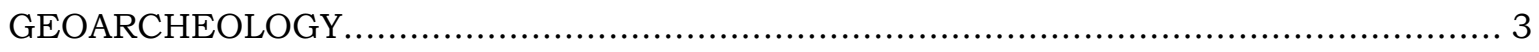

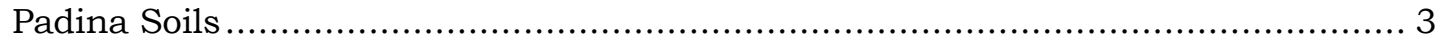

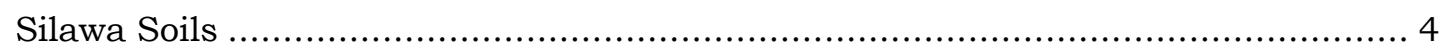

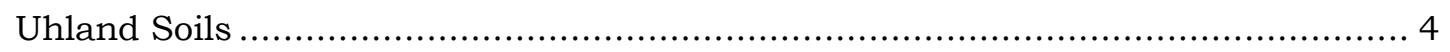

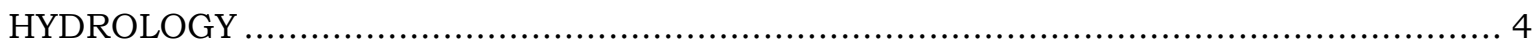

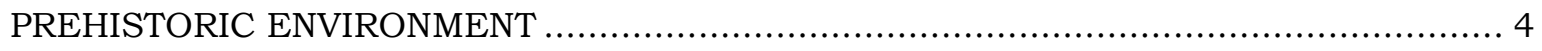

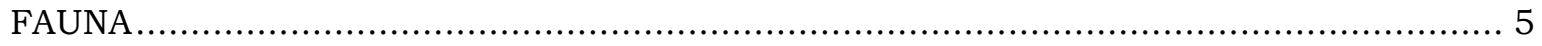

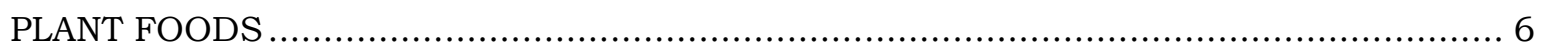

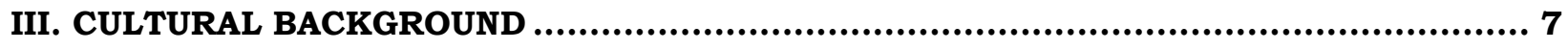

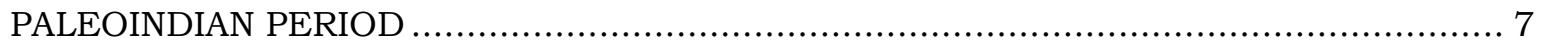

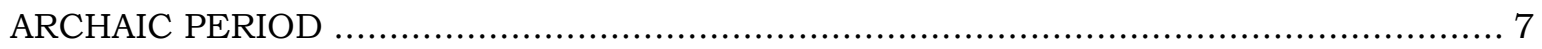

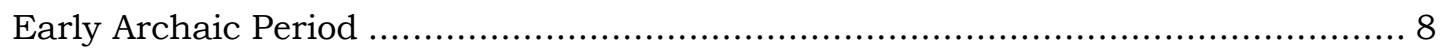

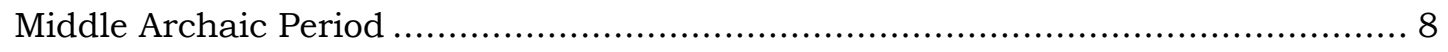

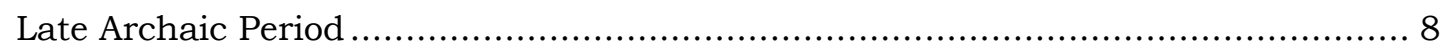

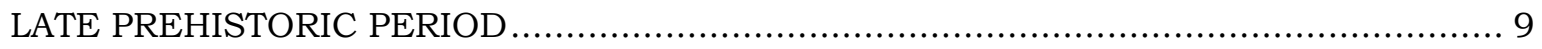

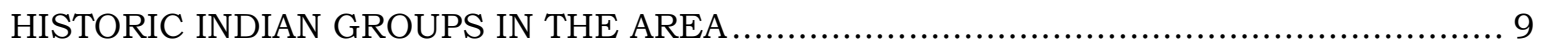

IV. PREVIOUS WORK AT THE SITE.........................................................11

V. TESTING OBJECTIVES.....................................................................15

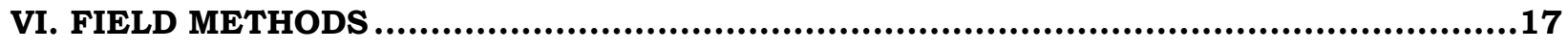

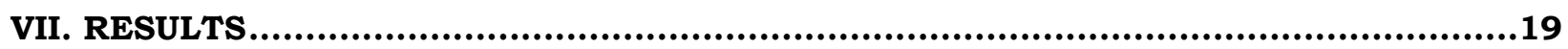

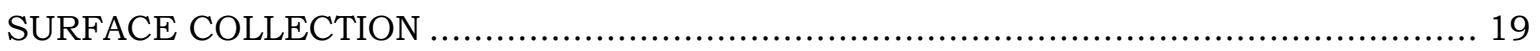

SHOVEL TESTING PROGRAM .............................................................. 19

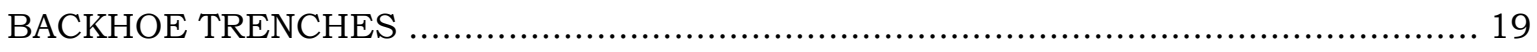

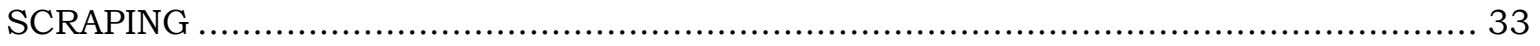

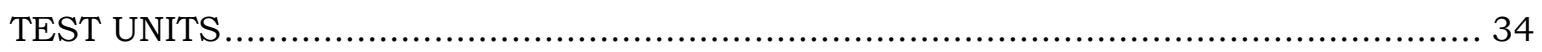

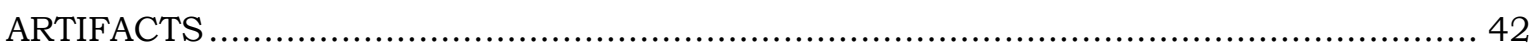

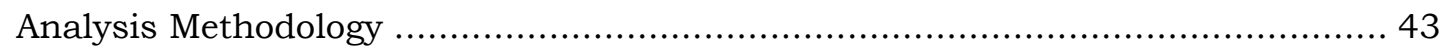

Raw Material Type ................................................................ 43

Thermal Alteration ................................................................ 46

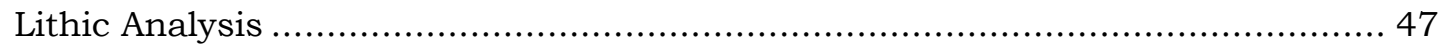

Tool Analysis ................................................................. 47

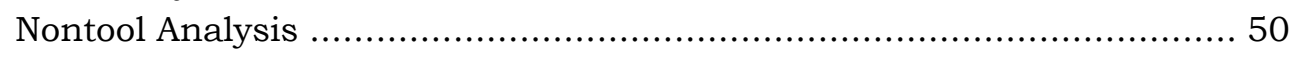

Thermally Altered Rock Analysis ........................................... 50

VIII. CONCLUSIONS AND RECOMMENDATIONS ...........................................53

IX. REFERENCES CITED ......................................................................55 
NRHP Eligibility Testing of Site 41LE326

\section{Appendices:}

A Site Location Map (map pocket; not for public disclosure)

B Specimen Inventory

C THC Concurrence 


\section{Figures}

Page

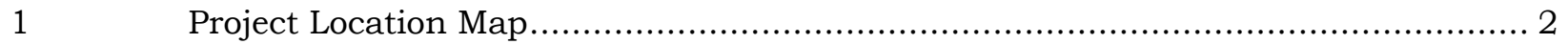

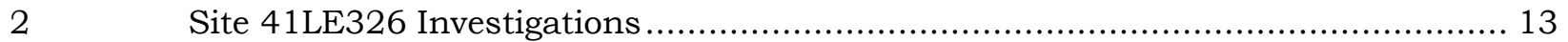

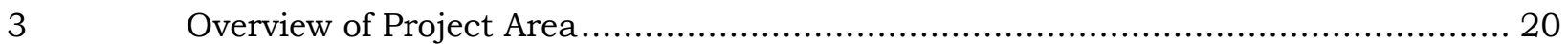

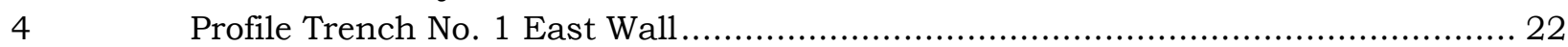

$5 \quad$ Profile Trench No. 2 East Wall ..................................................................... 23

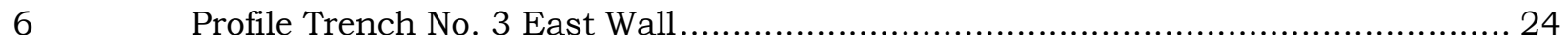

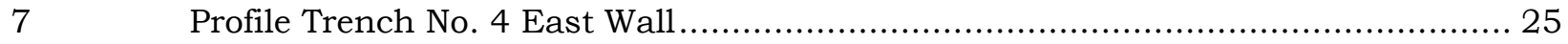

$8 \quad$ Profile Trench No. 5 West Wall .................................................................... 26

$9 \quad$ Profile Trench No. 6 East Wall ..................................................................... 27

$10 \quad$ Profile Trench No. 7 West Wall .................................................................. 28

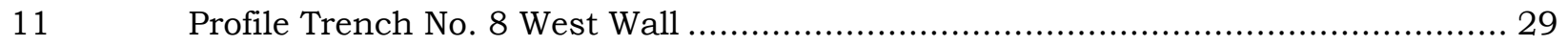

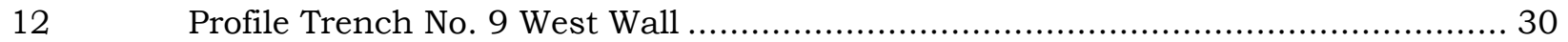

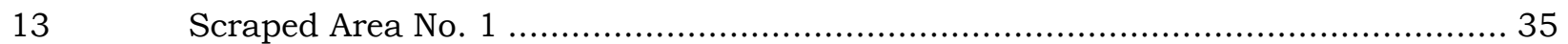

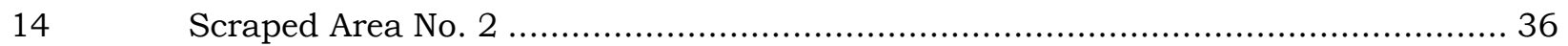

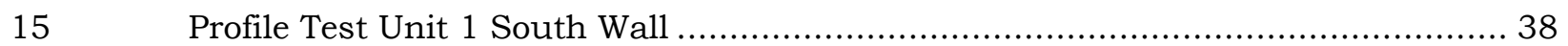

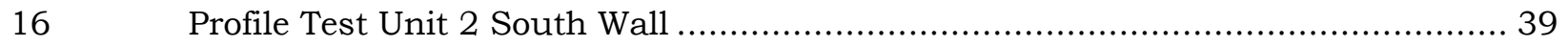

$17 \quad$ Profile Test Unit 3 South Wall .................................................................... 40

$18 \quad$ Profile Test Unit 4 South Wall ...................................................................... 41

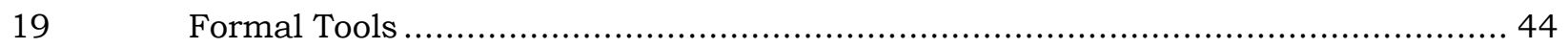




\section{Tables}

Page

1

2

3

4

5

6

7

8

9

10

11

12

13

14

15

16

17

18

19

Trench Characteristics, 41LE326.

21

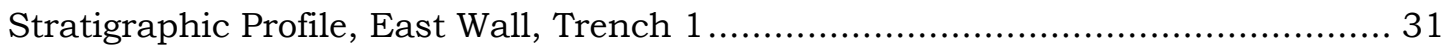

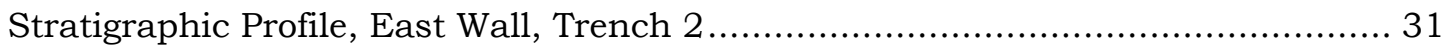

Stratigraphic Profile, East Wall, Trench 3 ................................................... 31

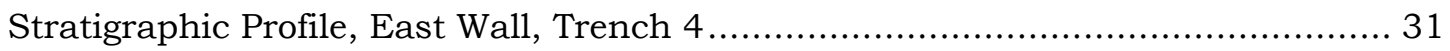

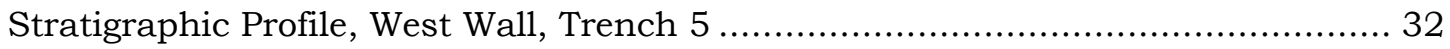

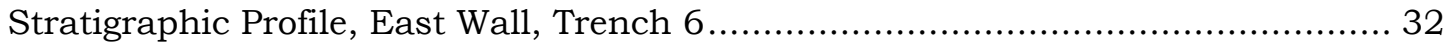

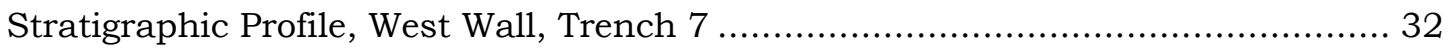

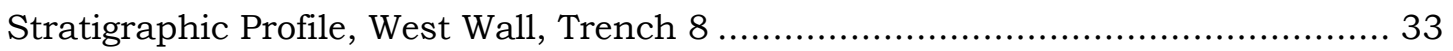

Stratigraphic Profile, West Wall, Trench 9 ................................................. 33

Stratigraphic Profile, West Wall, Scraped Area No. 1 .................................... 34

Stratigraphic Profile, West Wall, Scraped Area No. 2 ...................................... 34

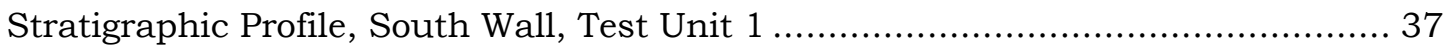

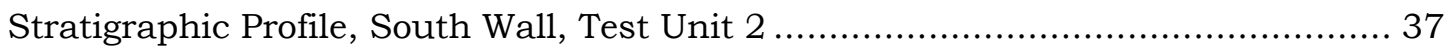

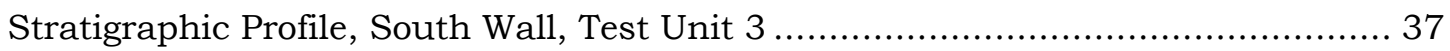

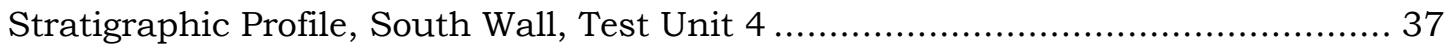

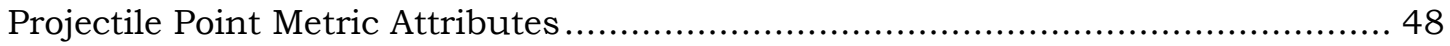

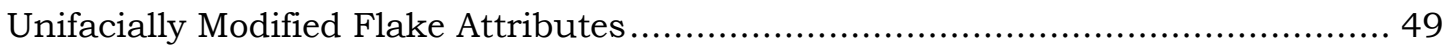

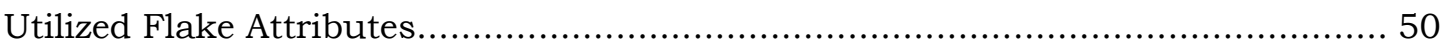




\begin{abstract}
Between March 5 and 12, 2007, PBS\&J conducted National Register of Historic Places eligibility testing at site 41LE326, under contract to the Texas Department of Transportation Environmental Affairs Division (TxDOT ENV) (CSJ No. 0211-03-032). This investigation was conducted in advance of proposed improvements to U.S. Highway 77 in central Lee County, Texas, under regulations of the National Historic Preservation Act, as amended (16 USC $\S 470$ et seq.) and the Antiquities Code of Texas (Title 9, chapter 191, Texas Natural Resource Code). Site 41LE326 is a prehistoric campsite that was initially recorded by PBS\&J in October 2006 during a cultural resources survey and is located on the south side of Middle Yegua Creek.

National Register testing consisted of the mechanical excavation of nine trenches totaling 47.3 linear meters and two scraped areas totaling approximately 55 square meters, and the manual excavation of nine shovel tests and four 1-x-1-meter test units. Analyses of artifacts recovered during testing suggest that occupation of the site likely occurred intermittently from at least the Late Prehistoric period and perhaps as early as the Middle Archaic period. Artifact categories recovered consisted of lithic manufacturing debris, lithic tools, burned matrix, and thermally altered rock.

Subsurface investigations at 41LE326 failed to encounter any evidence that intact buried prehistoric cultural deposits or features exist on the portion of the site within the TxDOT right of way. Based on stratigraphic data, lack of intact features, and low subsurface artifact density, it appears that the investigated portion of the site lacks integrity, and it is unlikely that additional archeological investigations within this portion of 41LE326 would contribute to our understanding of the area's prehistory. Therefore, the investigated portion of 41LE326 within the area of potential effect consisting of the existing right of way does not contribute to the site's eligibility for listing in the National Register of Historic Places and does not warrant designation as a State Archeological Landmark. No further investigation is recommended. Final curation of all collected materials will occur at the Texas Archeological Research Laboratory in consultation with TxDOT ENV.
\end{abstract}




\section{Acknowledgments}

The authors of this report would like to thank the many people who made contributions during the field, laboratory, and report preparation stages of this project. Special thanks go out to John Budd of the Texas Department of Transportation for providing commentary and review. The archeological field crew at the site included Michael Nash (Principal Investigator), Andrea Stahman (Project Archeologist), Amber Lutz, Jesus Alvarez, and Jenna Enright. Candace Wallace and Chris Heiligenstein processed and analyzed the artifacts in the laboratory under the supervision of the Laboratory Director, Linda Ellis. Ms. Wallace and Mr. Heiligenstein also helped in writing up the results of the lithic analysis, and Ms. Ellis contributed to the ground stone analysis section. Figures were prepared by David Kimmerling. The document was formatted by Chris Vidrick. Robert Rogers and Linda Nance served as technical editors. This report was written by Andrea Stahman, with contributions by Candace Wallace, Linda Ellis, and Chris Heiligenstein. 


\section{INTRODUCTION}

Between March 5 and 12, 2007, PBS\&J conducted National Register of Historic Places (NRHP) eligibility testing at prehistoric site 41LE326, under contract to the Texas Department of Transportation Environmental Affairs Division (TxDOT ENV). The site is located along U.S. Highway (US) 77, on the south side of Middle Yegua Creek in central Lee County, Texas (Figure 1).

The area of potential effect (APE) consists of that portion of site 41LE326 within the existing 200-foot (ft) or 61-meter (m) -wide highway right of way (ROW) situated on an upland terrace south of the creek to a depth of $6 \mathrm{ft}(1.8 \mathrm{~m})$. The portion of the existing ROW found to contain prehistoric remains consists of two strips, each measuring approximately $33 \mathrm{ft}(10 \mathrm{~m})$ east-west by 1,000 ft (305 m) north-south on each side of the paved highway, covering approximately 33,000 square $\mathrm{ft}\left(\mathrm{ft}^{2}\right)\left(6,100\right.$ square $\left.\mathrm{m}\left[\mathrm{m}^{2}\right]\right)$ (Appendix A).

Site 41LE326 was recorded by PBS\&J in 2006 during a cultural resources survey for proposed improvements to US 77, on the south side of Middle Yegua Creek (Ellis et al. 2009). Topographically, the area south of Middle Yegua Creek consists of a high terrace overlooking a steep slope and the narrow floodplain of the creek. The site's elevation ranges from approximately 350 to $370 \mathrm{ft}$ above mean sea level (amsl). During the current investigation, vegetation covering the site included cropped bermudagrass, yaupon, and oak trees. Ground surface visibility across the site ranged from 20 to 40 percent. 


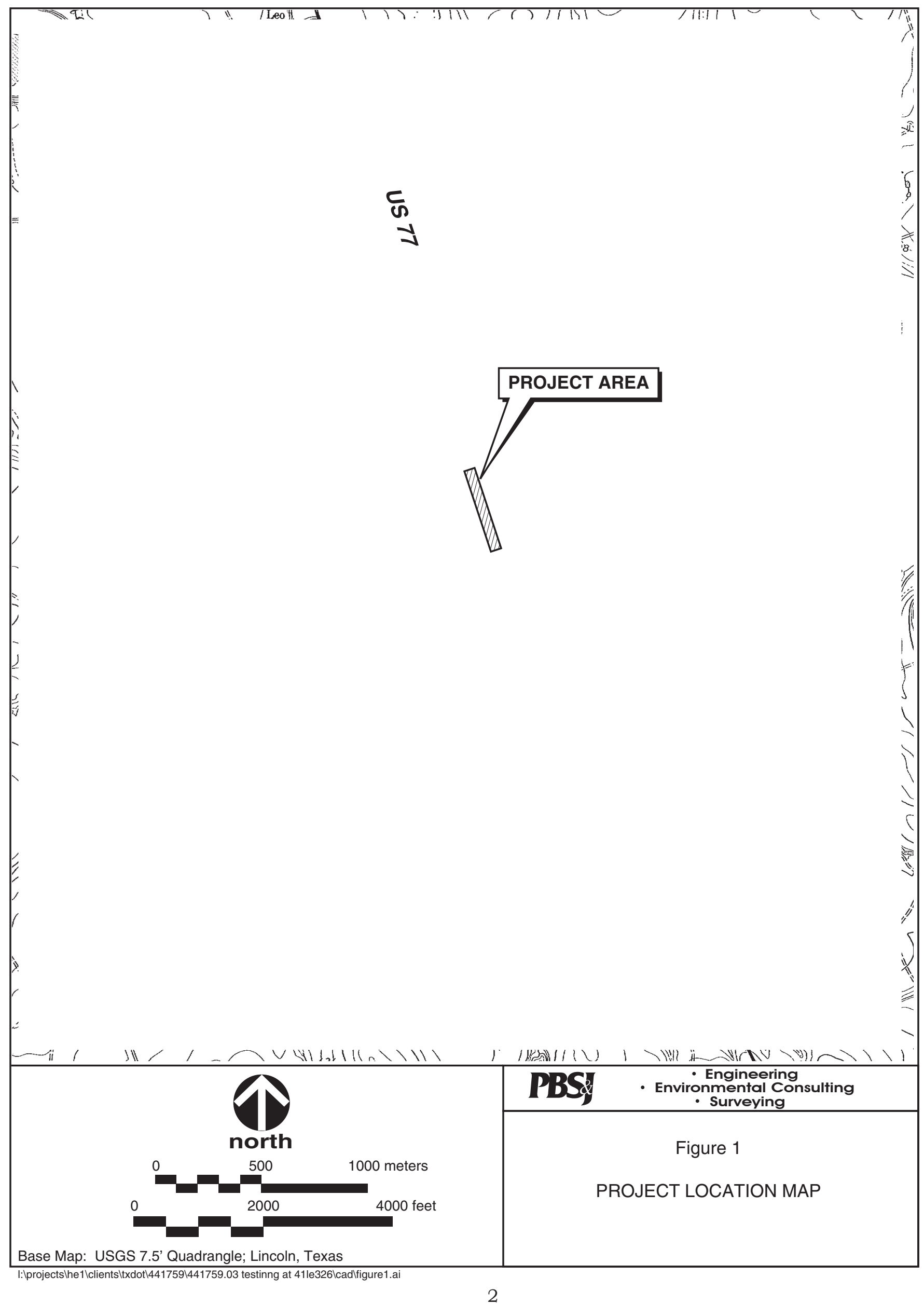




\section{ENVIRONMENTAL SETTING}

\section{MODERN CLIMATE}

Site 41LE326 is located at the periphery of the North Central and South Central climatic zones of Texas as defined by Blair (1950). The area is characterized by a relatively mild and uniform climate influenced by the warm and moist Gulf Stream air currents. The mean annual temperature for the area is 68.4 degrees Fahrenheit $\left({ }^{\circ} \mathrm{F}\right)$, with a mean maximum temperature of $94{ }^{\circ} \mathrm{F}$ in July and a mean minimum of $38{ }^{\circ} \mathrm{F}$ in January (Radian Corp. 1976). An average year sees temperatures reach $90^{\circ} \mathrm{F}$ or above on about 119 days, while freezing temperatures occur only on about 29 days. Annual precipitation averages 35.8 inches, and the heaviest accumulations usually occur between April and May.

\section{GEOARCHEOLOGY}

Geologically, site 41LE326 occurs on a relict stream terrace of Pleistocene age, mapped as Quaternary Terrace deposits by the Bureau of Economic Geology (1974). The terrace is an isolated remnant within the floodplain of Middle Yegua Creek. The terrace rises some $30 \mathrm{ft}$ above the floodplain, and ranges in elevation from about 350 to $370 \mathrm{ft}$ amsl.

While alluvial in origin, the sedimentary record of the terrace has been influenced by erosion and redeposition by colluvial and probably eolian forces. These postdepositional processes have occurred in conjunction with vertical displacement and mixing by biological agents including tree roots, burrowing animals, and insects. As a result, the archeological deposits present appear to have retained little stratigraphic integrity.

The soils of three soil series occur at or near 41LE326. Padina and Silawa soils have been mapped on the relict Pleistocene terrace. These developed in the sandy soils of the terrace and have been reworked to some extent by eolian, colluvial, and biological forces, which account for the occurrence of prehistoric artifacts in the sandy A and E soil horizons. Uhland soils occur adjacent to the site, in the floodplain of Middle Yegua Creek.

\section{Padina Soils}

Soils of the Padina series are very deep, well drained, and moderately permeable. They formed in thick sandy materials and are found on high terraces and uplands. Taxonomically, Padina soils are classified as Grossarenic Paleustalfs. These are Alfisols that occur on relatively stable landforms that had their genesis before the end of the Pleistocene (Soil Survey Staff 1975). They have a sandy epipedon that is often over $1 \mathrm{~m}$ in thickness and a typical horizon sequence of A-E-Bt1-Bt2. The occurrence of these soils on billowy-shaped landforms suggests some reworking by eolian forces (Soil Survey Staff 2007). The potential for this soil type to contain buried intact archeological deposits is considered moderate as these soils formed on relatively stable landforms in proximity to water resources but have been subjected to some postdepositional forces. 


\section{Silawa Soils}

Soils of the Silawa series are very deep, well drained, and moderately permeable. They formed in sandy and loamy sediments and are taxonomically classified as Ultic Haplustalfs, which are Alfisols that typically have a horizon sequence of A-E-Bt-BCt. Siliceous pebbles can occur throughout the soil column (Soil Survey Staff 2007). Silawa soils are typically found on relict stream terraces of Pleistocene age (Soil Survey Staff 1975). The potential for this soil type to contain buried intact archeological deposits is considered high.

\section{Uhland Soils}

Soils of the Uhland series consist of very deep, moderately well drained, and moderately slowly permeable soils that formed in alluvium. Taxonomically, they are classified as Aquic Haplustepts, which are Inceptisols that occur in frequently inundated floodplains (Soil Survey Staff 1975). Typically, the horizon sequence is A-Bw-Ab-Bwb-2Ab-2gB-3Ab. Buried soils (paleosols) and gleyed horizons are common (Soil Survey Staff 2007). The potential for this soil type to contain buried intact archeological deposits is also considered high.

\section{HYDROLOGY}

Middle Yegua Creek is within the Brazos River Drainage Basin, and at the site location is a third order (Strahler) stream. It has its headwaters approximately 32 kilometers $(\mathrm{km})$ west of the site and flows in a easterly direction into the Brazos River, near the town of Clay, Texas, approximately $76 \mathrm{~km}$ east of the site.

The valley of Middle Yegua Creek is relatively small, measuring less than $300 \mathrm{~m}$ along most of its course, though it reaches a width of approximately $700 \mathrm{~m}$ near its confluence with the Brazos River. Opposite of 41LE326, the floodplain is about $200 \mathrm{~m}$ wide. The creek is entrenched about $3 \mathrm{~m}$ below the site.

\section{PREHISTORIC ENVIRONMENT}

Pollen profile studies from east central Texas bogs have provided valuable data concerning the prehistoric vegetative environment in the region. In the earliest of these studies, Potzger and Tharp $(1947,1954)$ examined pollen profiles from three bogs in Milam, Lee, and Robertson counties in east central Texas. The record of each of these bogs suggested four stages of postglacial climatic change: cool-moist, warmdry, warm-moist, and warm-dry. It was demonstrated that boreal conifers, including fir, spruce, and pine, predominated in east central Texas during the earliest periods. Later, Pinus spp. decreased abruptly, giving way to grasses and oaks. Uppermost levels in all three bogs showed increases in hickory (Carya).

Bryant (1977), in his investigations of the Boriack Bog in Lee County, reiterated evidence for a continuing trend toward less-mesic environments from the fullglacial period (22,500 to 14,000 B.P.) to the 
postglacial period (10,000 B.P. to present). He suggested that central Texas, during the late fullglacial period, supported a vegetative community of open deciduous forests (with species such as oak, birch, alder, and ash) mixed with some conifers (pine and spruce) that contained an understory of grasses and shrub vegetation. With the onset of the postglacial period, the pollen record indicated a decline in the number of arboreal species and an increase in the dominance of grasses and herbaceous species.

The oldest radiocarbon-dated peat deposit in east central Texas was a thin peat lens found underlying the Walleye Creek site (41LE57) in northwestern Lee County. That sample dated to 22,710 \pm 110 B.P., or within the fullglacial period (Rogers 1999:6-8). Pollen identified within the peat lens contained arboreal species including oak, pine, hickory, and alder. Palynological data described by Camper (1991), which were retrieved from Patschke Bog (also in Lee County) from a fullglacial context (17,280 \pm 270 B.P.), contained similar taxa, but included some spruce. A cool, moist climate for this time period is suggested. Later, during the late-glacial period (14,000-10,000 B.P.) there was an increase in oak and a decrease in spruce, and the period is interpreted as representing a time of gradual vegetational change. By the end of the period, the pollen record suggests the region was an open deciduous woodland or parkland with a somewhat warmer climate, but still quite moist. After about 10,000 B.P. there was a significant drop in arboreal species with the exception of oak and hickory/pecan as the open deciduous woodlands gave way to an oak savanna (Camper 1991).

Johnson and Goode (1994) used the palynological data and geomorpholocial studies of Nordt (1992, 1993) and vertebrate fossil evidence from Halls Cave (Toomey 1993) to chart Holocene temperature fluctuations during the Archaic and Late Prehistoric periods. They concluded that the generally moist climate of the early Archaic was followed by a drier climate, which lasted from the Middle Archaic (about 5000 B.P.) until about 2500 B.P. On the Edwards Plateau, the archeological record is replete with examples of burned rock middens and the processing of succulents and tubers during this xeric time. It is less certain whether the subsistence practices changed east of the Balcones Escarpment, where the numerous creeks, springs, and rivers assuredly would have offered sanctuary from the drier conditions.

Wetter conditions returned during the latter part of the Archaic period, which continued into the early part of the succeeding Late Prehistoric period, when a dry interval of shorter duration occurred sometime before 950 B.P. This later dry period correlates with episodes of channel incisions throughout the southern plains in the drainage basins of the Arkansas, Red, Trinity, Brazos, and Colorado Rivers (Hall 1990). This dry interval may have lasted as long as two centuries with moist conditions returning around 750 B.P.

\section{FAUNA}

Site 41LE326 lies within the transition zone from forest to savannah ecotones. This results in an intermixing of forest-adapted species and prairie or grassland species. This is especially true of birds and the larger, more mobile mammals (Blair 1950). Forested areas contain some species that are existing on the western limits of their range, and non-forested areas contain some species not found farther to the east. 
The intergradation of habitat types and the activity patterns of wildlife species result in some overlapping of faunal communities. Forest-dwelling species may venture into open areas around forest stands, and species characteristic of non-forested habitats may occasionally be found in forested areas. Edges or ecotones between major habitats are preferred by many wildlife species. This is true to some extent for species such as the white-tailed deer (Odocoileus virginianus), eastern cottontail (Sylvilagus floridanus), and bobwhite (Colinus virginianus), as well as many songbirds. These transition areas are preferred, not only for the diversity of food materials available, but also for the usually dense cover provided through the characteristic overlap of vegetation communities.

Other fauna characteristic of the area include the fox squirrel (Sciurus niger), raccoon (Procyon lotor), gray fox (Urocyon cinereoargenteus), opossum (Didelphis virginiana), nine-banded armadillo (Dasypus novemcinctus), bobcat (Felis rufus), and swamp rabbit (Sylvilagus aquaticus).

Several mammals which formerly occurred in the study area are now extirpated. The following species may have been important to Indians and other early settlers of the region, either as food or competitors, or perhaps for cultural reasons: red wolf (Canis rufus), black bear (Ursus americanus), jaguar (Felis onca), ocelot (F. pardalis), collared peccary (Tayassu tajacu), and pronghorn (Antilocapra americana) (Schmidly 1983). Two birds that formerly occurred in the region but are now extinct include the passenger pigeon (Ectopistes migratorius) and the Carolina parakeet (Conuropsis carolinensis ludoviciana) (Texas Ornithological Society 1984).

Other mammals, such as the feral hog (Sus scrofa), did not occur in the region in prehistoric times, but were introduced by settlers of European ancestry. The nine-banded armadillo is likewise new in the area. This animal has expanded its range in eastern Texas since 1900, possibly because of progressive climatic changes, encroaching human civilization, overgrazing, and decimation of large carnivores (Schmidly 1983).

\section{PLANT FOODS}

The location of site 41LE326 coincides with the transition from Oak Woodlands to Blackland prairie. This results in an intermixing of forest-adapted species and prairie or grassland species. A multitude of useful wild plants would have been available to the site's occupants. Comparison of modern botanical lists (Hatch et al. 1990) and ethnobotanical, ethnohistorical, and archeological records identifies several potentially important plants available prehistorically at this location. Although by no means an exhaustive list, these include wormseed (Chenopodium sp.), common persimmon (Diospyros virginiana), eastern prickly pear (Opuntia compressa), yaupon (Ilex vomitoria), pecan (Carya illinioensis), common greenbriar (Smilax rotundifolia), dewberry, Woodsorrel, sunflower, Sugar Hackberry, mustang grape, and wild onion. 


\section{CULTURAL BACKGROUND}

Culturally, site 41LE326 lies within the generally accepted boundaries of the Central Texas Archeological Region, as defined by Prewitt (1981) and Collins (2004). Based on previous research, the general cultural history of this area can be divided into four primary chronological and developmental periodsPaleoindian, Archaic, Late Prehistoric, and Historic. These divisions are believed to reflect changes in sociocultural integration and subsistence technology through time, as revealed by material remains and settlement patterns.

\section{PALEOINDIAN PERIOD}

Prior to 8000 B.P. human adaptations in the central region of Texas varied, and no single broadly defined Paleoindian lifeway applies. Excluding a pre-Clovis period for which no empirical evidence exists, the period has been divided into Early Paleoindian and Late Paleoindian (Collins 1998). The Early Paleoindian period has been assigned to occupations and materials contemporaneous with Pleistocene megafauna while the Late Paleoindian period is contemporaneous with early Holocene fauna.

Clovis is the earliest of the cultural horizons of central Texas and dates to between 11,200 and 10,900 B.P. In addition to Clovis points, bifaces, flakes, and prismatic blades characterize the culture. The culture was not based solely on the pursuit of megafauna, as Clovis peoples probably exploited a number of large and small animals and an array of plants as well. Unlike Clovis, sites yielding Folsom points are primarily associated with bison hunting, and are almost always found at sites in grasslands.

Toward the end of the Early Paleoindian period, Dalton and San Patrice points appear. The heartland of the people who first made Dalton points was in the westernmost woodlands of Missouri and northern Arkansas (Johnson 1989:16). San Patrice points were first identified in northwest Louisiana and typify a woodlands culture, and were probably contemporaneous with the Dalton culture. Both San Patrice and Dalton points have been recovered from sites in nearby Bastrop and Grimes Counties (Johnson 1989:Table 2; Rogers and Foster 1994:66). The Golondrina type is more commonly found in the central and southwestern parts of the state.

\section{ARCHAIC PERIOD}

The long Archaic period occupies two-thirds of the prehistoric timetable of both central Texas and the Inland Coastal Plain. It was a time of exploitation of local plants and animals, and a greater diversity in materials is apparent, especially in ground stone tools. At sites in both central Texas and the Inland Coastal Plain, large amounts of thermally altered stones occur in ovens, hearths, and middens. Obviously, the long (7,500 years) interval occupied by the Archaic period is indicative of a successful adaptation. The Archaic has been divided into three periods: Early Archaic (8000-6000 B.P.), Middle Archaic (6000-4000 B.P.), and Late Archaic (4000-1200 B.P.). 


\section{Early Archaic Period}

Work along the southern and eastern edge of the Edwards Plateau has uncovered sites with a large number of burned rock features dating to this period, and some sites have yielded evidence of structures (Collins 1998:64). Clear Fork gouges and Guadalupe bifaces dating from the Early Archaic have been cited as evidence of woodworking (Johnson 1991:158). Many of the Early Archaic sites are situated in areas that contained localized mesic habitats, though climatic evidence suggests oscillations in rainfall (Johnson and Goode 1994:20). Diagnostic projectile points from the Early Archaic period include Angostura, Baird, Hoxie, and Wells.

\section{Middle Archaic Period}

Johnson and Goode (1994) subdivide the Middle Archaic (ca. 6000-4000 B.P.) into three style intervals (Bell-Andice-Calf Creek, Taylor, and Nolan-Travis). The earlier intervals witnessed a change in lithic technology characterized by thin triangular bifaces with long thinning flakes emanating from the base. These artifacts may have served as knives or the tips of darts, lances, or spears (Collins 1998). The climate during the early part of the Middle Archaic was mesic, and the above artifacts are believed to have been used primarily in bison hunting, perhaps by peoples who migrated into the region from the prairie margins of eastern Oklahoma. It appears likely that bison vanished from the region during the latter part of the Middle Archaic and the widespread and long-lived Nolan-Travis point styles represent a response to the shift in the exploitation of other species, principally deer. Burned rock middens became numerous in the limestone-rich Edwards Plateau during the latter part of the Middle Archaic.

\section{Late Archaic Period}

The Late Archaic was a long and important period that began about 2300 B.C. and lasted some 3,000 years. Johnson and Goode (1994) subdivide the period into subperiods. The Late Archaic I subperiod began with the appearance of Bulverde dart points and coincided with a hotter, dryer climate. The Bulverde dart point type was followed by the appearance of Pedernales points, which may have developed on the Edwards Plateau, where they are particularly abundant. Subsequent dart point types attributed to the Late Archaic I subperiod include Lange, Marshall, Montell, and Castroville.

The Late Archaic I subperiod witnessed increases in population. In easterly portions of central Texas, burned rock middens reached their most abundant level during this subperiod, particularly during the time when Pedernales points were in vogue (Collins 1998:65). It was during this time that the first evidence of contacts between central Texas and the Texas coast occurs in the archeological record, as evidenced by the recovery of a conch columella bead in association with a Marshall dart point at the Loeve-Fox site (41WM230; Prewitt 1982).

The Late Archaic II subperiod lasted until about A.D. 600, and corresponded to a somewhat more mesic climate interval (Johnson and Goode 1994:37). Along the eastern edges of the Edwards Plateau, burned rock middens became less common as the xeric plants cooked in them became less abundant. Evidence of 
contacts between peoples living in the eastern part of central Texas and the Texas coast increased. Among many sites where marine shell ornaments have been found are the Locke Farm site (41CM25) in Comal County, the Pat Parker site (41TV88) in Travis County, and the Loeve-Fox site. Reciprocal trade of Edwards chert outward from central Texas also occurred. This evidence of cross-cultural contacts and trade in ceremonial items reflects religious movements that were occurring in the eastern U.S. (Johnson and Goode 1994:38). Diagnostic dart points from this subperiod include Marcos, Ensor, Fairland, and Darl types. These point types tend to be somewhat smaller than those used during the Late Archaic I subperiod, which may reflect a greater reliance on deer and smaller mammals.

\section{LATE PREHISTORIC PERIOD}

Separated from the Late Archaic period by the advent of the bow and arrow and ceramics, the Late Prehistoric period (also known as the Post Archaic or Neo-Archaic) has been divided into two phases: the earlier Austin Phase and the later Toyah Phase (Jelks 1962; Prewitt 1981, 1985). Austin Phase sites date to between about 1250 and 650 B.P. and are often characterized by Scallorn arrow points, basin shaped hearths and cemeteries. Toyah Phase sites date from 650 B.P. to 200 B.P. and usually contain Perdiz arrow points and ceramics of the types Leon Plain and less often Doss Redware. Johnson (1994a), while avoiding the use of the Austin and Toyah phases, saw the change in arrow point types as reflecting a change from the Archaic-seeming lifestyle of the Scallorn folk to the buffalo hunting Perdiz folk, largely in response to climatic change from mesic to dry conditions.

\section{HISTORIC INDIAN GROUPS IN THE AREA}

Among the inheritors of the Toyah culture were the Sanan speakers, such as the Emet, Sana, Sijame, and Toho, living east of the Edwards Plateau, who, while using a Toyah stone toolkit, produced pottery of a different sort than produced at Classic Toyah culture sites (Johnson and Campbell 1992).

In addition to Sanan speakers, Tonkawa-speaking groups are known to have been in the region between the Guadalupe and Trinity rivers. They were not native to the area; however, as their ancestral homeland was located far to the north. Tonkawa speakers probably did not arrive in east central Texas until about the middle of the eighteenth century.

Spanish expeditions in Texas afford the primary evidence of the relevant historic Indian tribes in east central Texas during the late seventeenth and early eighteenth centuries. These expeditions include the 1689 expedition of Governor Alonso de León, the 1691-1692 expedition of Governor Domingo Terán de los Ríos, the Espinosa-Olivares-Aguirre expedition of 1709, Ramón’s expedition of 1716, Alarcón’s expedition of 1718, and Rivera's Inspection tour of 1727 (Campbell 1983; Foster 1995). The Indians encountered during those journeys included indigenous Sanan speakers and displaced and migrating tribes from well outside the region such as the Jumano of west Texas, the Wichita-speaking Yojuane of northcentral Oklahoma, and the Simaomo and Tusonibi of northeastern Mexico. Large congregations of tribes met the Spaniards along the San Marcos and Colorado rivers, where they had been hunting and trading among themselves and with the Tejas or Caddo. Ramon's 1716 Expedition encountered a large band of 
native peoples, collectively designated the Rancheria Grande, encamped along the middle Brazos River in what is now Milam County that may have included Tonkawa, Ervipiame, Pamaye, Payaye, Cantona, Mescale, Jarame, and Sijame (Weddle 2010). Some of the Indians had horses. One trail used by the Caddo on their hunting forays from east Texas crossed the Colorado at La Grange in neighboring Fayette County. They were encountered in 1690 by Governor de León at a prominent bluff overlooking the Colorado River referred to as Buenavista, which some researchers believe is Monument Hill (Foster 1995:40).

Another late-seventeenth-century trail in the vicinity of 41LE326 was the famous El Camino Real, or Old San Antonio Road. A route for the trail, defined by Zively in 1915-1916 and later designated the Camino Real National Historic Trail, generally followed what is now State Highway 21 through Lee County between Bastrop and Caldwell, passing approximately 3 miles south of site 41LE326 (McGraw and Hardin 1998:230-234). Although variations of the trail used by the Spanish in this area appear to have passed to the north and south of Highway 21, an account by Francisco Céliz of the 1718 Alarcón Expedition notes that Xanac, Emet, Too, Malleye, Huyugan, and Curmicai peoples were encountered within 10 leagues of Yegua Creek, which would put them within the vicinity of Lee County (Robbins 1998:361).

Campbell (1986) lists several tribes believed to have been indigenous to the Bastrop area, about $42 \mathrm{~km}$ southwest of 41LE326. These tribes include Apayxam, Caisquetebana, Cantona, Catqueza, Cava, Chaguantapam, Cumercai, Emet, Mayeye, Menanquen, Panasiu, Sana, Tohaha, and Toho. 


\section{PREVIOUS WORK AT THE SITE}

During the cultural resources survey of the project area, 12 shovel tests were excavated within the APE south of Middle Yegua Creek and 2 backhoe trenches were excavated north of and downslope from 41LE326 (Figure 2) (Ellis et al. 2009). All shovel tests were excavated in 10-centimeter (cm) levels. Seven of the 12 shovel tests were culturally positive, yielding 36 specimens of nondiagnostic chert debitage, 3 pieces of heat-altered chert, 1 petrified wood flake, and 1 tested chert cobble. Survey-phase shovel test (SS) 1 was positive from levels 1 through 4 and from levels 6 through 8 with 17 secondary and tertiary flakes and flake fragments. SS 3 was positive within levels 4 and 9 with 2 tertiary flakes. SS 4 was positive with 1 tertiary flake in Level 5, 1 tertiary flake and 1 petrified wood flake in Level 8, and 1 thinning flake in Level 10. SS 5 was positive from levels 7 through 10 with 6 tertiary and thinning flakes. SS 6 was positive within Level 5 with 5 tertiary flakes and 1 tested chert cobble. SS 7 was positive within Level 2 with 1 tertiary flake. SS 9 was positive for 2 tertiary flakes, one in Level 1 and one in Level 3, and 3 pieces of heat-altered chert in Level 5. Along with subsurface findings, numerous artifacts including debitage, tested cobbles, and heat-altered chert were visible on eroded portions of the ground surface (Ellis et al. 2009).

Backhoe trenching was also conducted during survey investigations (Ellis et al. 2009). Results of backhoe trenching indicated that the narrow floodplain below the site on the south side of the creek is characterized as Uhland fine sandy loam that is frequently flooded alluvium found on 0 to 1 percent slopes (Natural Resources Conservation Service 1989). Soils of the upper terrace, which includes portions of site 41LE326, have been mapped as Silawa loamy fine sand found on 1 to 5 percent slopes, and Padina loamy fine sand found on 5 to 15 percent slopes (Natural Resources Conservation Service 1989). Of the two trenches excavated during survey, one contained modern cultural materials, while the other contained no cultural materials. 



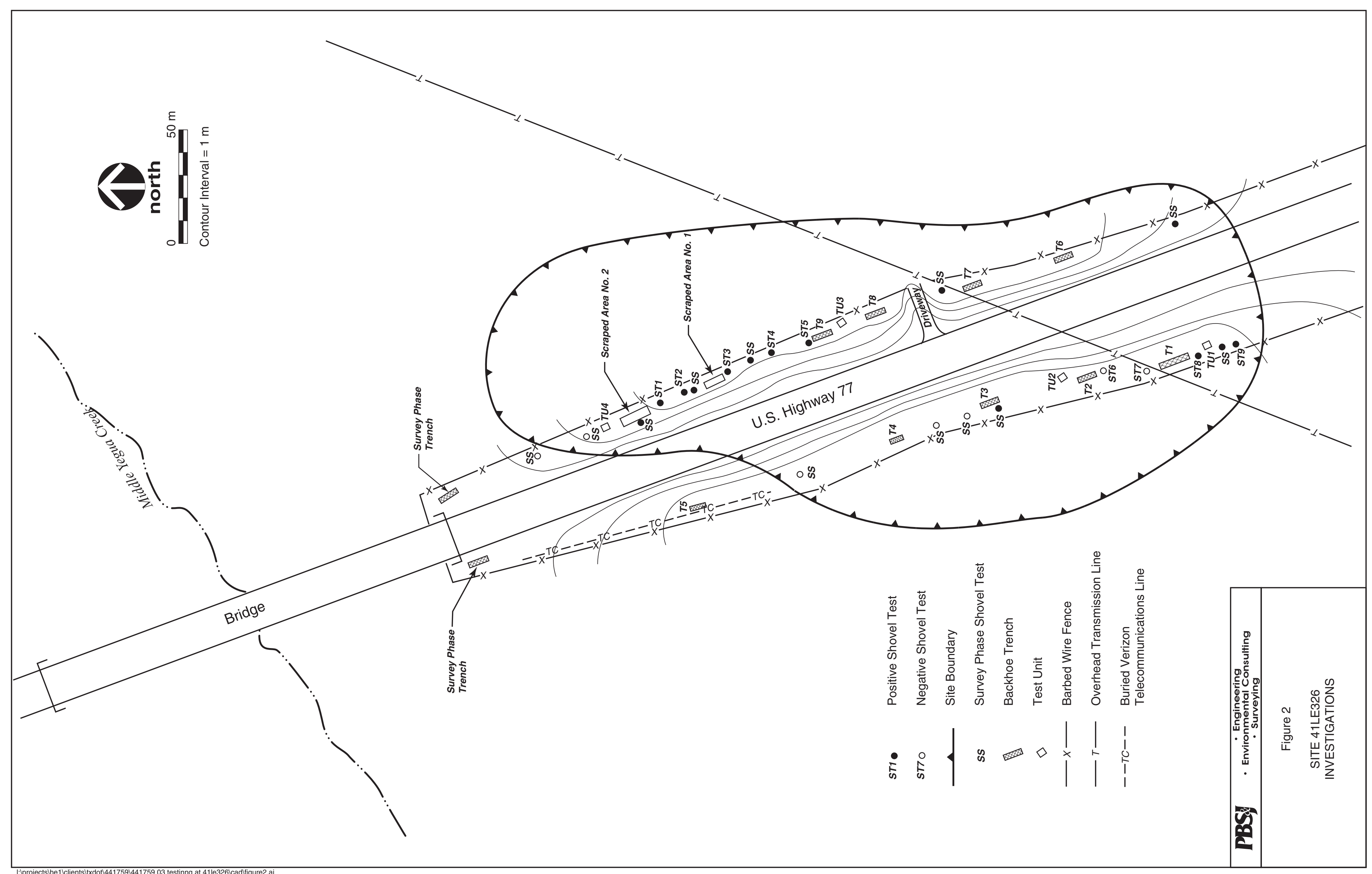





\section{TESTING OBJECTIVES}

The primary goals of archeological investigation at 41LE326 were presented to TxDOT in a written scope of work and included in Texas Antiquities Permit No. 4439 issued by the Texas Historical Commission (THC). These goals were related directly to evaluating NRHP eligibility under Criterion D in 36 CFR 60.4 and equivalent criteria under 13 TAC 26.8, including (1) to assess the age and extent of cultural deposits at the site; (2) to assess the potential for the site to contain buried prehistoric features with intact faunal or floral remains or intact lithic procurement and stone tool manufacturing activity areas; and (3) if site 41LE326 is found to be eligible for listing in the NRHP or for designation as a State Archeological Landmark (SAL), to assess the effect of proposed construction on the site and provide site-specific recommendations for mitigation of adverse impact within the proposed ROW. 



\section{FIELD METHODS}

The field methods undertaken to accomplish the goal of assessing SAL and NRHP eligibility of site 41LE326 consisted of five phases: (1) detailed surface inspection and mapping of the site with the establishment of a metric grid system; (2) a program of shovel testing and backhoe trenching to delimit the horizontal and vertical extent of the site within both sides of the ROW, as previously recorded; (3) mechanical scraping and geoarcheological characterization of areas that yielded evidence of cultural features or increased artifact density; (4) controlled excavation of test units over features and intact cultural deposits if encountered during shovel testing or trenching; and (5) controlled excavation of a sample of additional features, if encountered during mechanical excavations.

A total of nine shovel tests, nine backhoe trenches, two scraped areas totaling about $55 \mathrm{~m}^{2}$, and four 1-x-1-m test units were excavated during the eligibility testing investigations at 41LE326. Each was

excavated until sterile subsoil was encountered. Controlled hand excavation through test units removed a total of 2.8 cubic meters of site matrix. 



\section{RESULTS}

\section{SURFACE COLLECTION}

Prior to the test excavations, a controlled surface inspection of the site was conducted to assess the nature and density of surface artifactual remains. Surface inspection of the upper terrace was limited by the dense growth of bermudagrass. As a result, the only artifacts observed were two modern clear glass shards. These artifacts were not collected.

\section{SHOVEL TESTING PROGRAM}

Controlled shovel testing was conducted in areas of the project area where backhoe trenching was not possible, due to the acute grade of the sloping terrace within the ROW on either side of US 77. In these areas, shovel tests were excavated at approximate 15-m intervals (see Figure 2). In total, nine shovel tests (ST) were excavated, with seven proving positive for cultural materials. Each shovel test was excavated in 10-cm levels to an average depth of 55 centimeters below surface (cmbs), terminating when sterile subsoil was encountered. All material was sifted through $0.63-\mathrm{cm}$ screens (1/4-inch hardware cloth). Shovel tests produced a total of 73 artifacts including 1 Bulverde dart point, 1 uniface fragment, 3 unifacially modified flakes, 1 utilized flake, 1 core, 41 pieces of lithic debitage, 24 fire-cracked rock fragments, and 1 ground stone fragment. Cultural materials were recovered during the shovel testing program from the surface to a depth of $80 \mathrm{~cm}$. The majority (96 percent) were retrieved from levels 1 through 6 (0 to $60 \mathrm{cmbs}$ ), with the highest percentage (25 percent) encountered in Level 2 (10 to 20 cmbs). See Appendix B for a more-detailed description of the presence and quantity of recovered cultural materials.

\section{BACKHOE TRENCHES}

In addition to shovel testing, nine trenches were mechanically excavated by a backhoe within the site, all of which were oriented roughly parallel to the long axis of the ROW (see Figure 2). Five trenches were located on the western side of the ROW, and four trenches were excavated on the eastern side of the ROW. All trenches were excavated atop the upper terrace above the creek. Soil was removed by the backhoe in shallow layers of approximately $20 \mathrm{~cm}$ or less until subsoil was encountered. No cultural materials were observed within these trenches in either the disturbed matrix or side walls. Trench matrix was not screened. Profiles of each trench were recorded on standard PBS\&J field forms and photo documented with digital photography. Table 1 details the general characteristics of each of the excavated trenches.

Trench placement in the ROW was limited due to the steep slope of the upper terrace immediately east and west of US 77 (Figure 3). Trenches were placed near the fence line at the ROW margin where the ground surface was fairly level, but also very narrow. A particularly narrow area of level ground on the east side of the ROW prevented backhoe excavation between ST 3 and ST 5 (see Figure 2). 


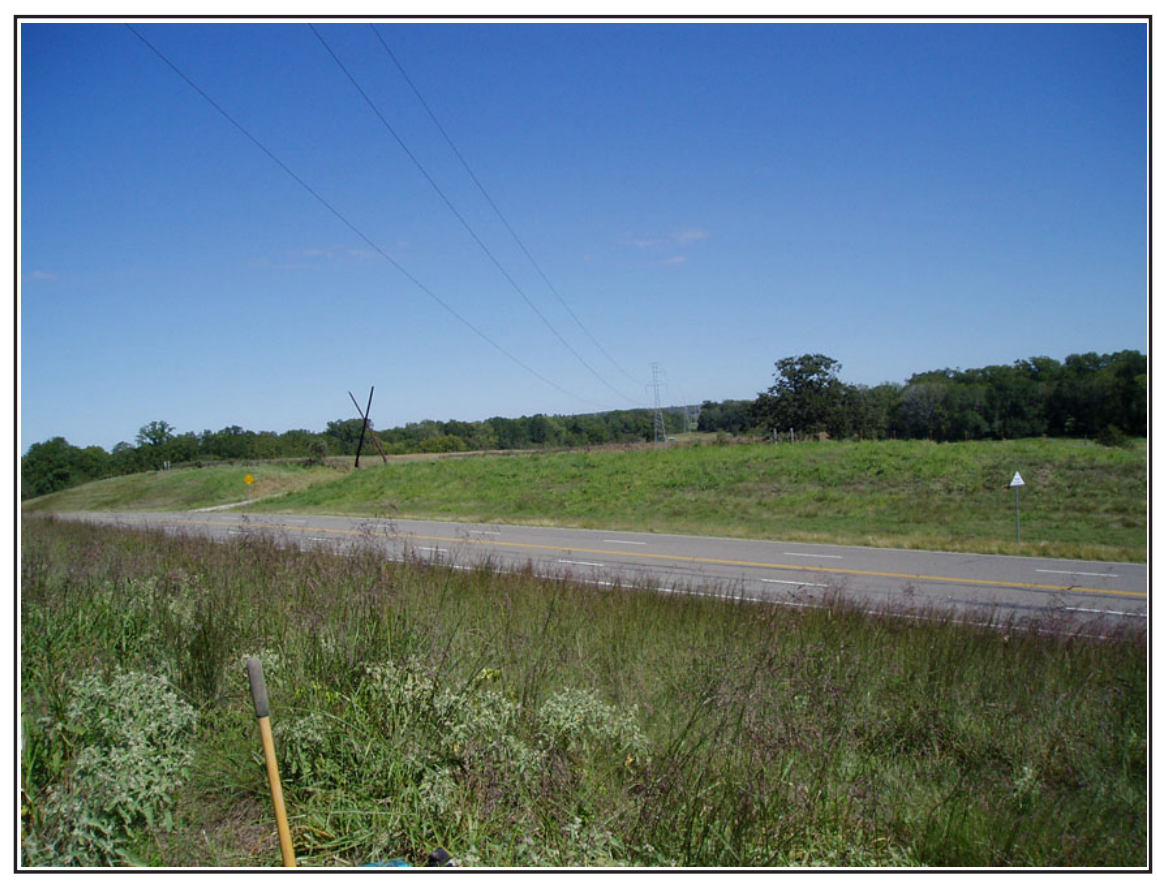

a) Overview of APE, facing north.

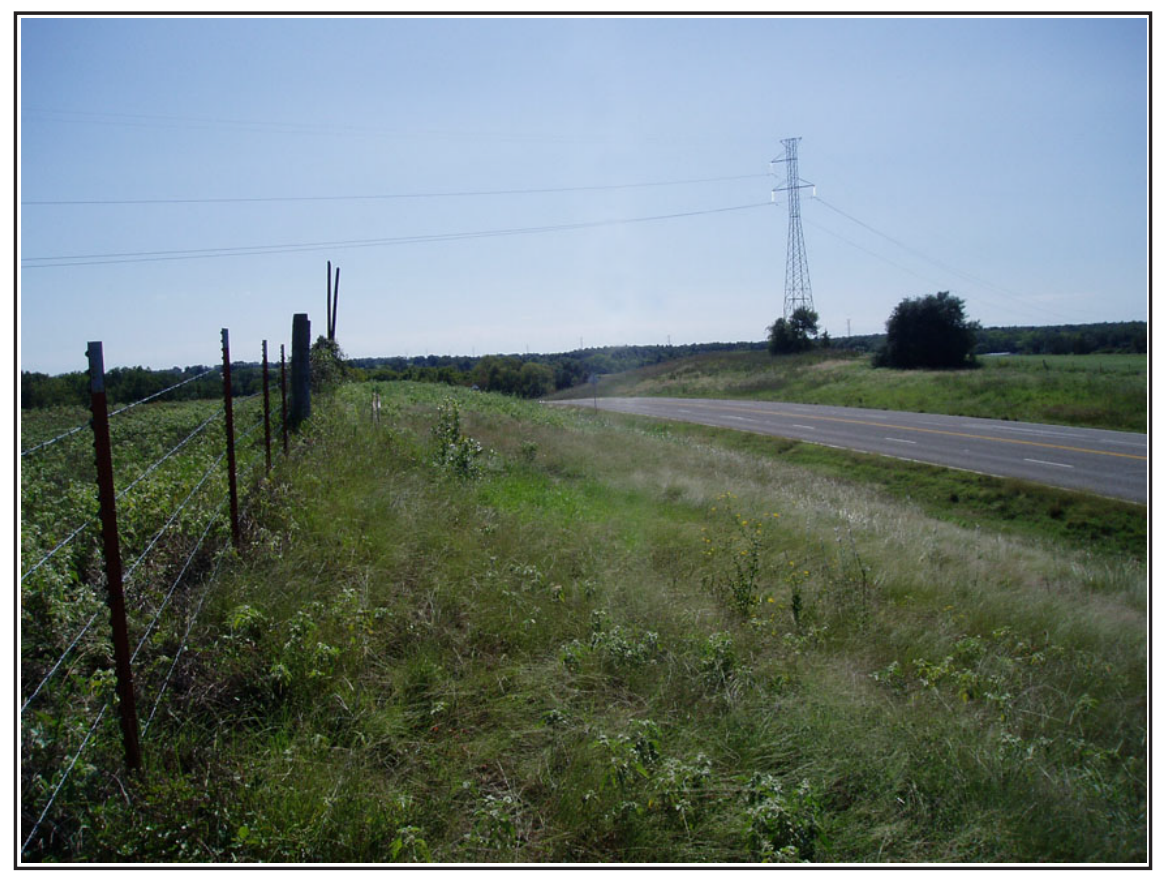

b) Overview of APE, facing south.

\begin{tabular}{|c|c|}
\hline PBS\& & $\begin{array}{c}\text { E Engineering } \\
\text { Environmental Consulting } \\
\text { - surveying }\end{array}$ \\
\cline { 2 - 2 } & Figure 3 \\
OVERVIEW OF PROJECT AREA \\
\end{tabular}


Table 1: Trench Characteristics

41LE326

Trench 1: $7 \mathrm{~m}$ long, $62 \mathrm{~cm}$ wide, $76 \mathrm{~cm}$ deep, oriented northwest-southeast, described profile exposed in eastern wall

Trench 2: $6 \mathrm{~m}$ long, $62 \mathrm{~cm}$ wide, $60 \mathrm{~cm}$ deep, oriented northwest-southeast, described profile exposed in eastern wall

Trench 3: $6 \mathrm{~m}$ long, $62 \mathrm{~cm}$ wide, $2.0 \mathrm{~m}$ deep, oriented northwest-southeast, described profile exposed in eastern wall

Trench 4: $3.5 \mathrm{~m}$ long, $62 \mathrm{~cm}$ wide, $1.9 \mathrm{~m}$ deep, oriented northwest-southeast, described profile exposed in eastern wall

Trench 5: $5 \mathrm{~m}$ long, $62 \mathrm{~cm}$ wide, $1.65 \mathrm{~m}$ deep, oriented northwest-southeast, described profile exposed in western wall

Trench 6: $4 \mathrm{~m}$ long, $65 \mathrm{~cm}$ wide, $3.0 \mathrm{~m}$ deep, oriented northwest-southeast, described profile exposed in eastern wall

Trench 7: $5 \mathrm{~m}$ long, $65 \mathrm{~cm}$ wide, $110 \mathrm{~cm}$ deep, oriented northwest-southeast, described profile exposed in western wall

Trench 8: $5 \mathrm{~m}$ long, $65 \mathrm{~cm}$ wide, $1.8 \mathrm{~m}$ deep, oriented northwest-southeast, described profile exposed in western wall

Trench 9: $5.8 \mathrm{~m}$ long, $65 \mathrm{~cm}$ wide, $90 \mathrm{~cm}$ deep, oriented northwest-southeast, described profile exposed in western wall

Trench stratigraphy was fairly consistent between the western and eastern sides of the ROW with minor variations (figures 4-12, tables 2-10). Trenches 1 and 2 on the west side and Trench 9 on the east side contained similar profiles, with the upper 25 to $40 \mathrm{~cm}$ consisting of yellowish brown fine sandy clay loam or sandy loam overlying red clay. Only Trench 1 featured an ephemeral stratum of mottled yellowish brown and very pale brown fine sandy loam. Stratigraphic deposits within Trenches 3 and 6 indicate a deep (extending up to approximately $3 \mathrm{~m}$ below the surface) yellowish brown sandy loam deposit overlying clay. This stratum occurs as an approximately 50-m-wide diagonal swath through the project area and may indicate a relict channel. North of this swath on the west side of the ROW, Trench 4 displayed a less thickly bedded exposure of the same yellowish brown fine sandy loam overlying a very thinly bedded reddish brown clay loam above a second fine sandy loam layer and finally clay. To the north of the sandy loam swath on the east side of the ROW, deposits in trenches 7 and 8 show a slightly darker fine sandy loam stratum featuring a thin upper zone of organic materials, indicating a buried surface, overlain by additional layers of fine to very fine sandy loam. No cultural materials were encountered within this stratum, and the location of each trench to either side of an excavated or "sunken" driveway suggests that matrix overlying this stratum was redeposited from the driveway and thus is not likely to have capped a prehistoric surface that might have contained in situ cultural materials. Farther north, near the toeslope of the upper terrace, Trench 5 features an upper stratum of redeposited sediments overlying the ever-present yellowish brown fine sandy loam and clay. Munsell colors were determined in the field under ambient moisture and lighting conditions. 


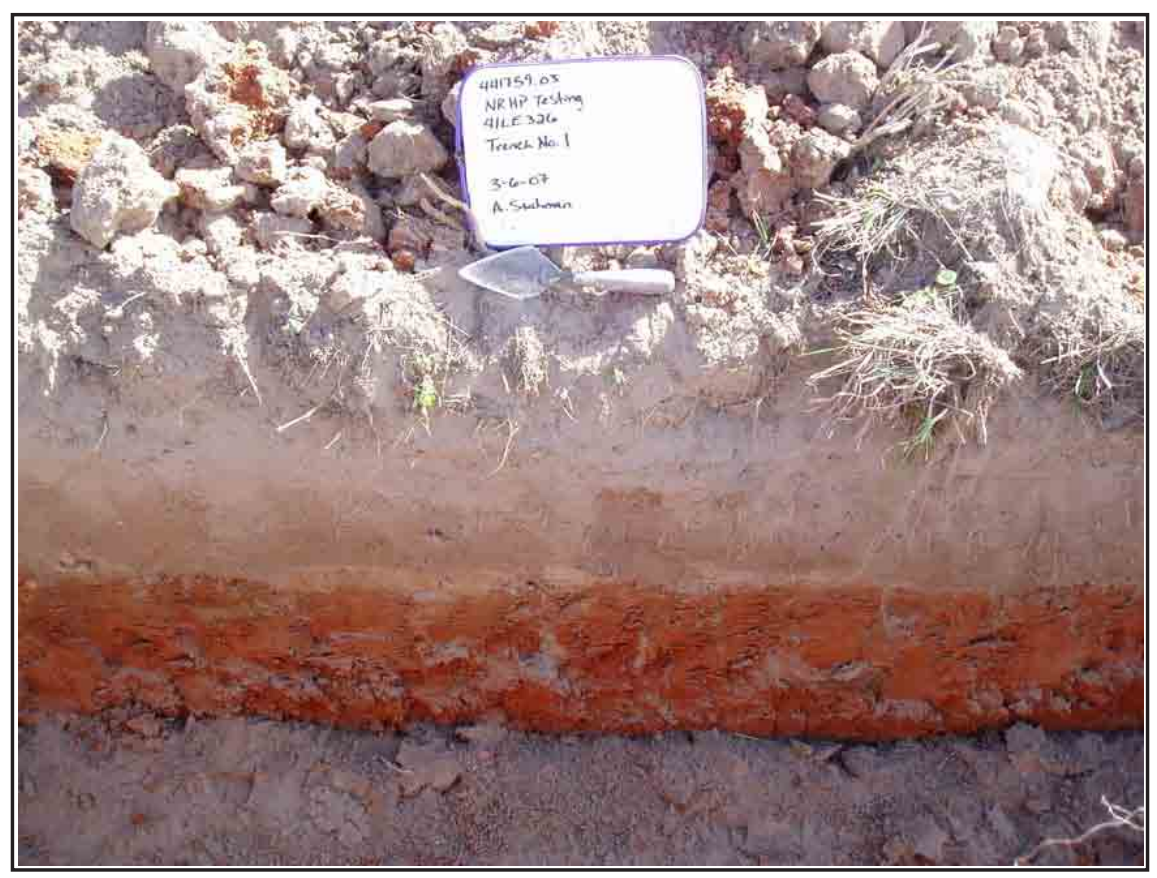

a) Section of profile, facing east.
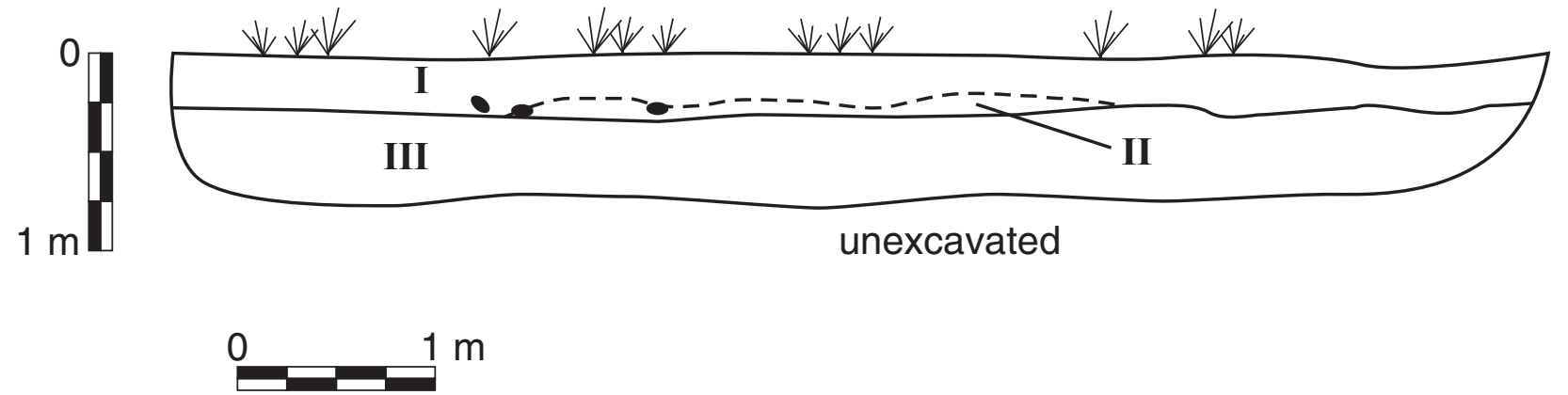

b) Profile of east wall.

- Rock (natural)

Note: No cultural materials were observed in the trench sidewalls.

\section{PBS\& • Environmental Consulting}

Figure 4

TRENCH NO. 1

EAST WALL PROFILE 


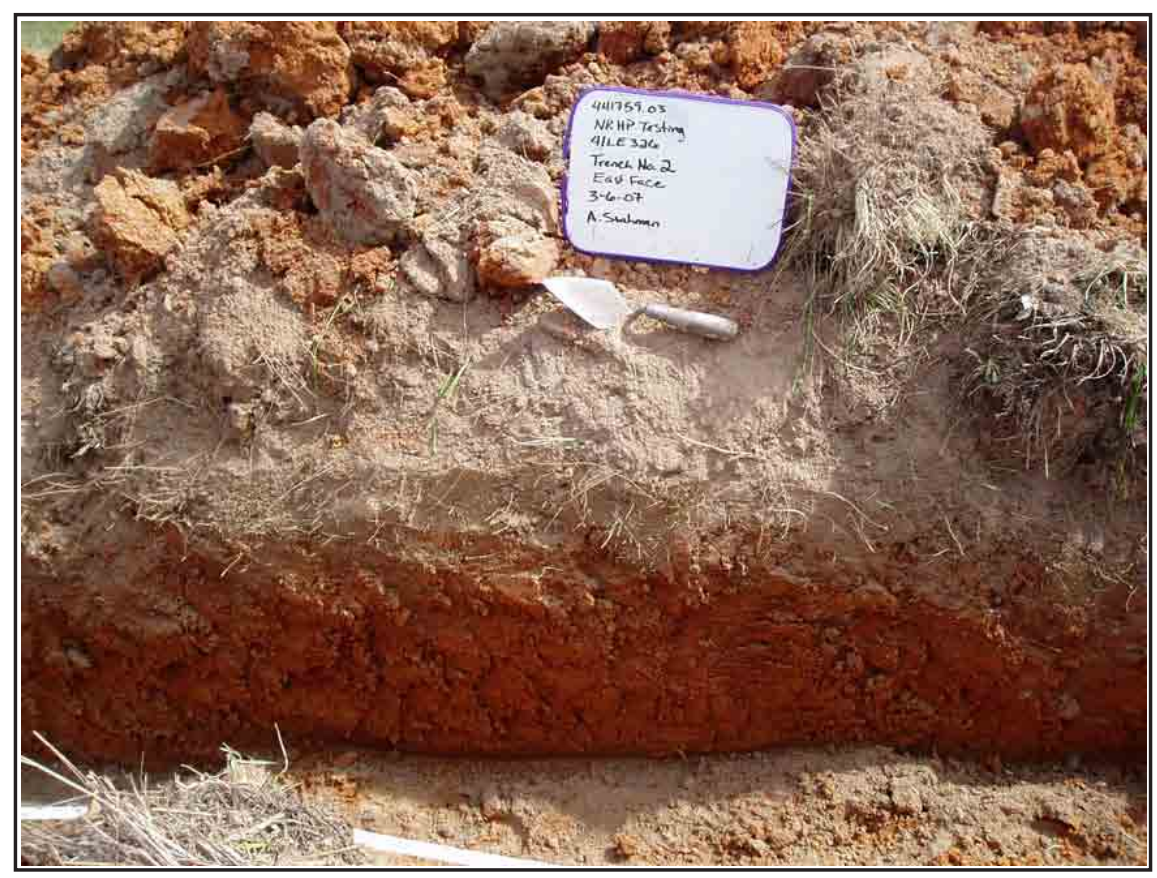

a) Section of profile, facing east.

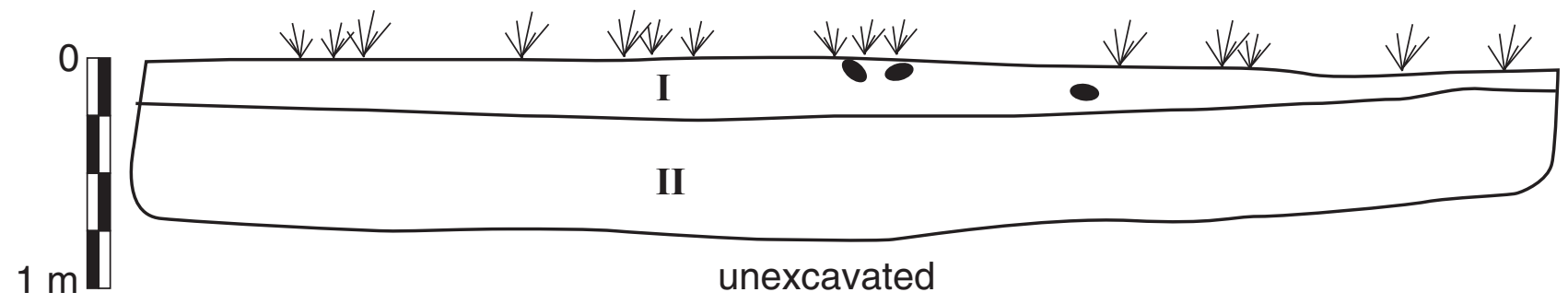

b) Profile of east wall.

- Rock (natural)

Note: No cultural materials were observed in the trench sidewalls.

\section{PBS\& • Environmental Consulting}

Figure 5

TRENCH NO. 2

EAST WALL PROFILE 


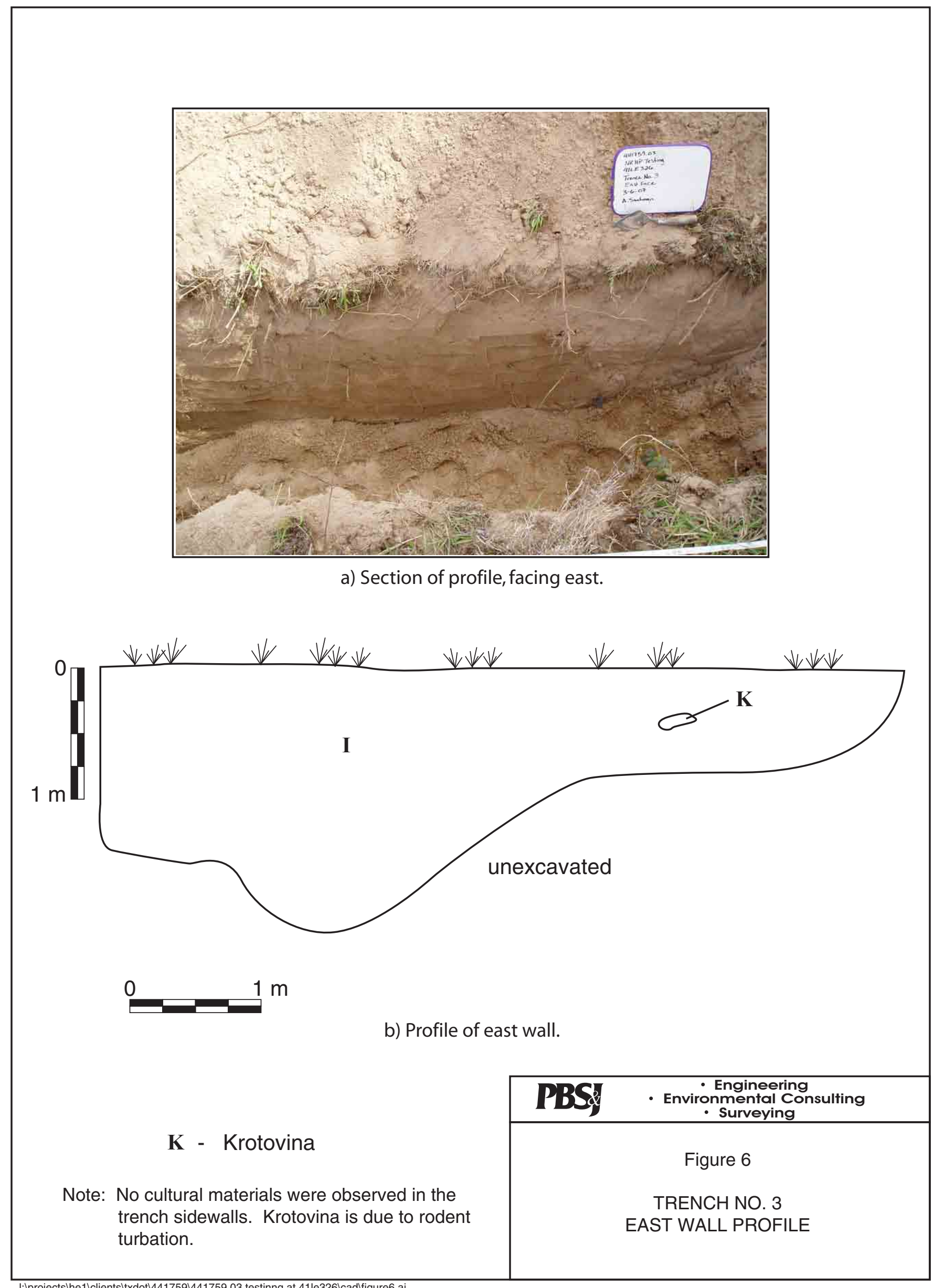

I:|projects|he1|clients|txdot|441759\441759.03 testinng at 41le326lcadlfigure6.ai 


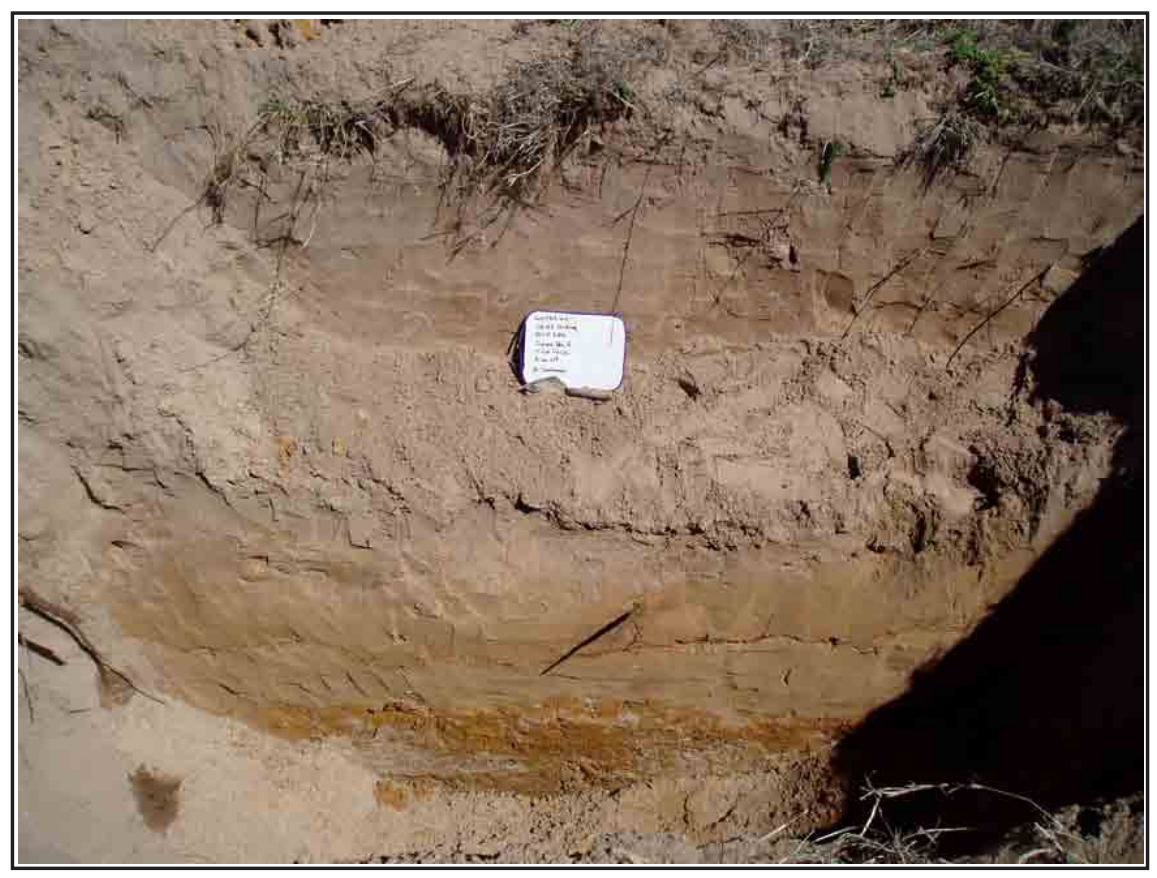

a) Section of profile, facing east.
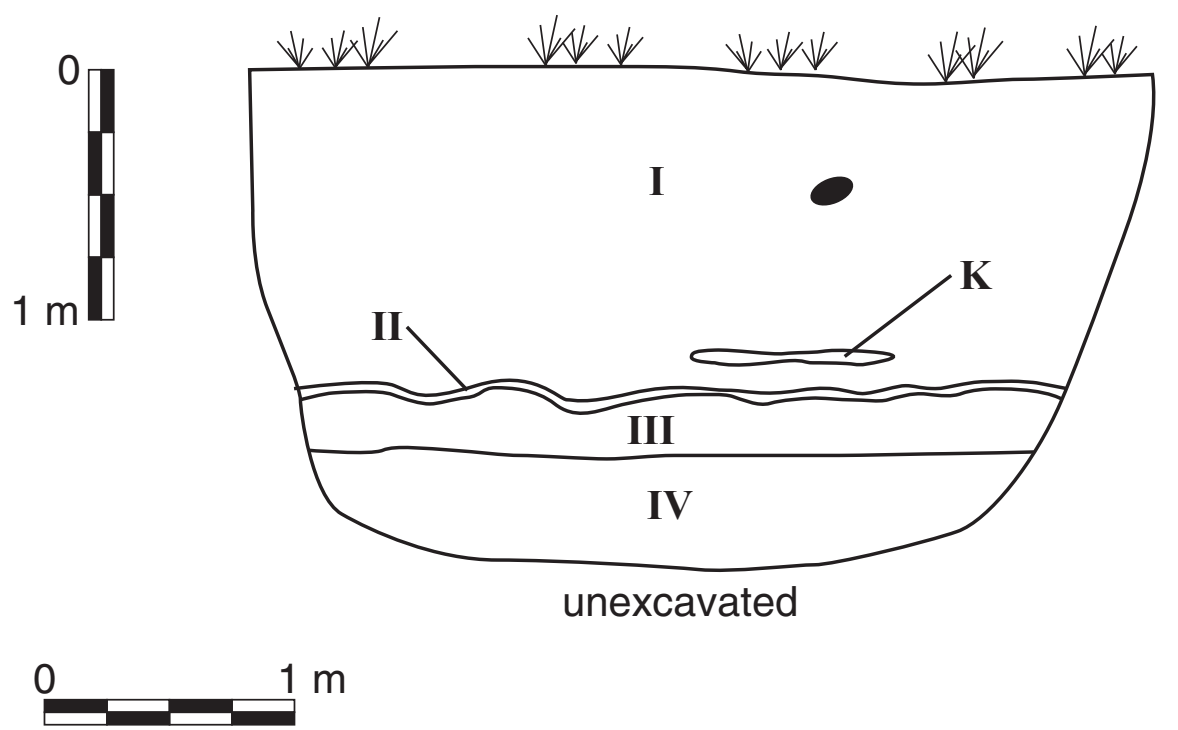

b) Profile of east wall.

\section{- Rock (natural) \\ K - Krotovina}

Note: No cultural materials were observed in the trench sidewalls

\section{PBS\& - Environmental Consulting}

Figure 7

TRENCH NO. 4

EAST WALL PROFILE 


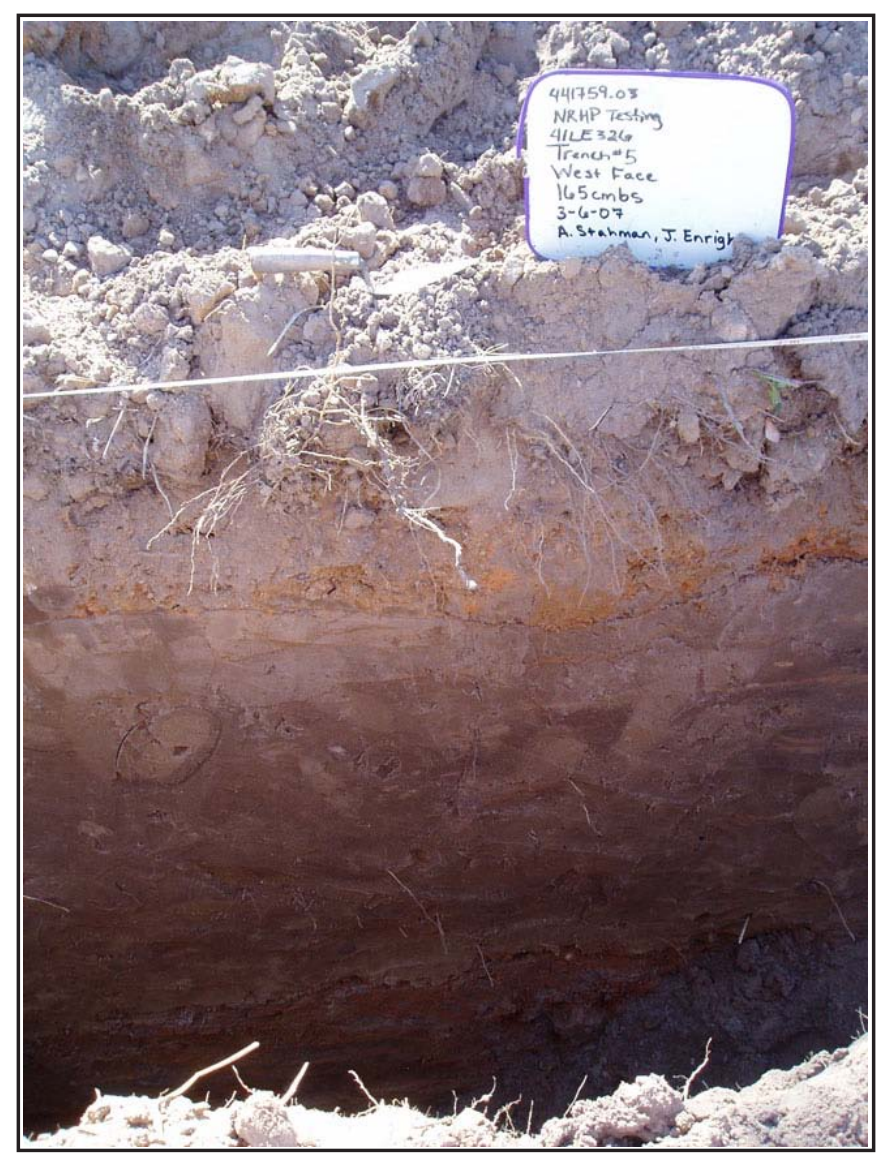

a) Section of profile, facing west.

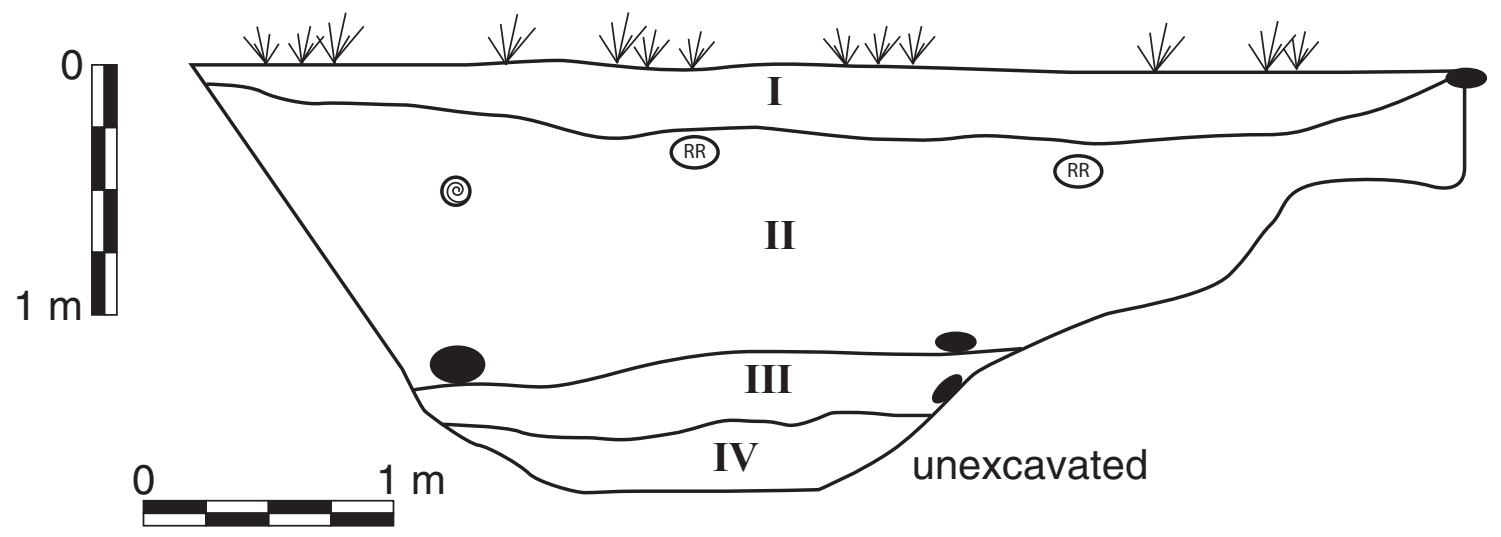

b) Profile of west wall.

- Chert Cobbles (unaltered)

(2) - Root

®R - Rodent Run

Note: No cultural materials were observed in the trench sidewalls.

\section{PBS\& • Environmental Consulting}

Figure 8

TRENCH NO. 5

WEST WALL PROFILE 


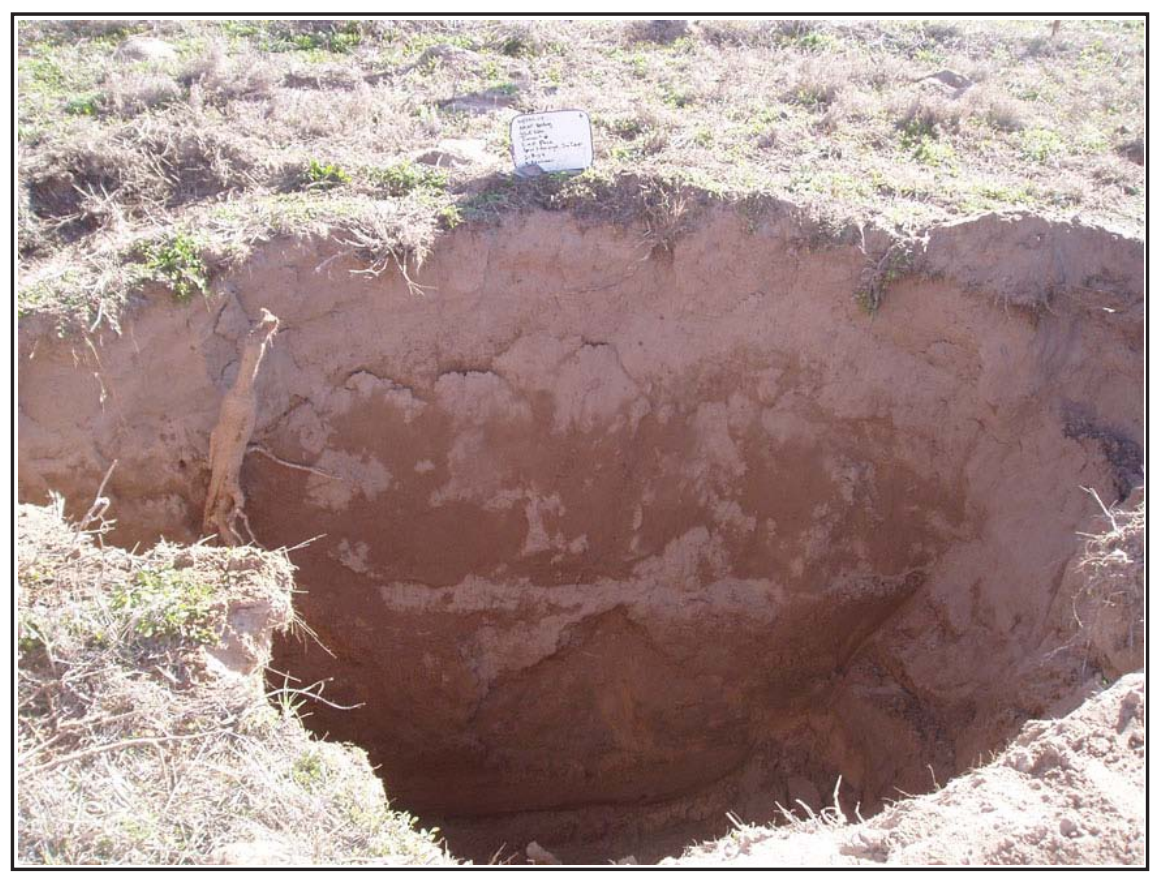

a) Section of profile, facing east.

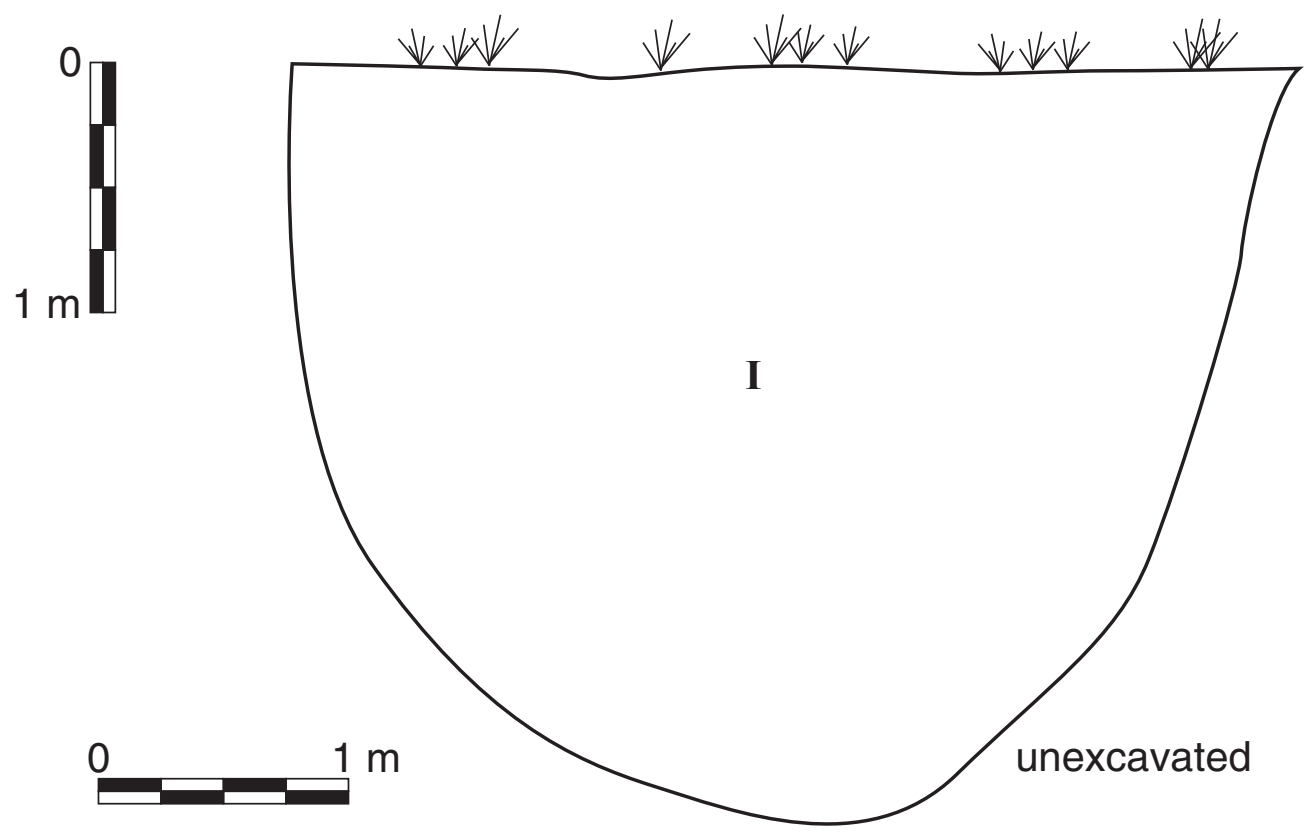

b) Profile of east wall.

Note: No cultural materials were observed in the trench sidewalls.

\section{PBS\& • Environmental Consulting}

Figure 9

TRENCH NO. 6

EAST WALL PROFILE 


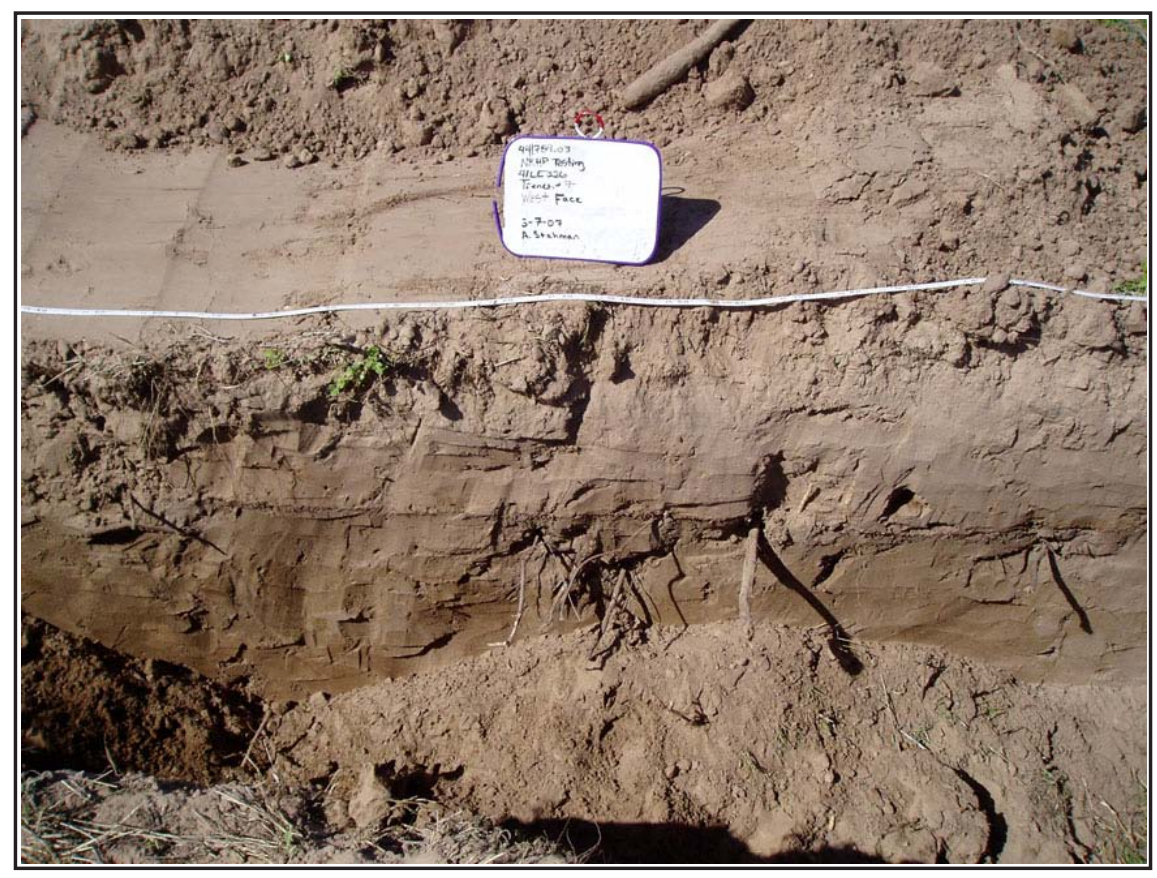

a) Section of profile, facing west.

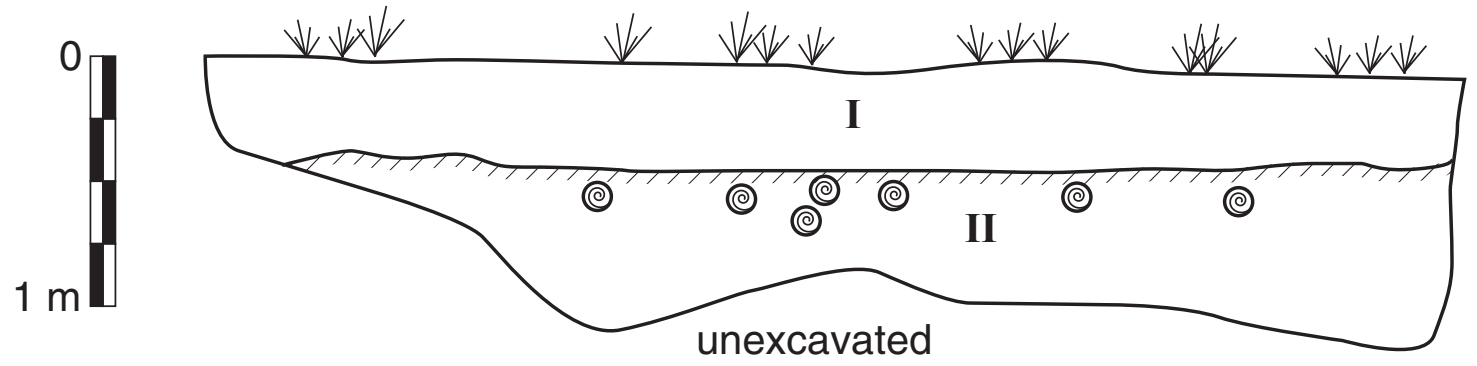

b) Profile of west wall.

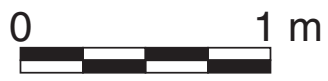

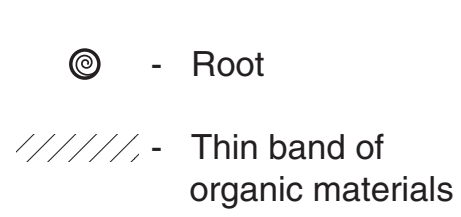

Note: No cultural materials were observed in the trench sidewalls.
PBS\& • Environmental Consulting

Figure 10

TRENCH NO. 7

WEST WALL PROFILE 


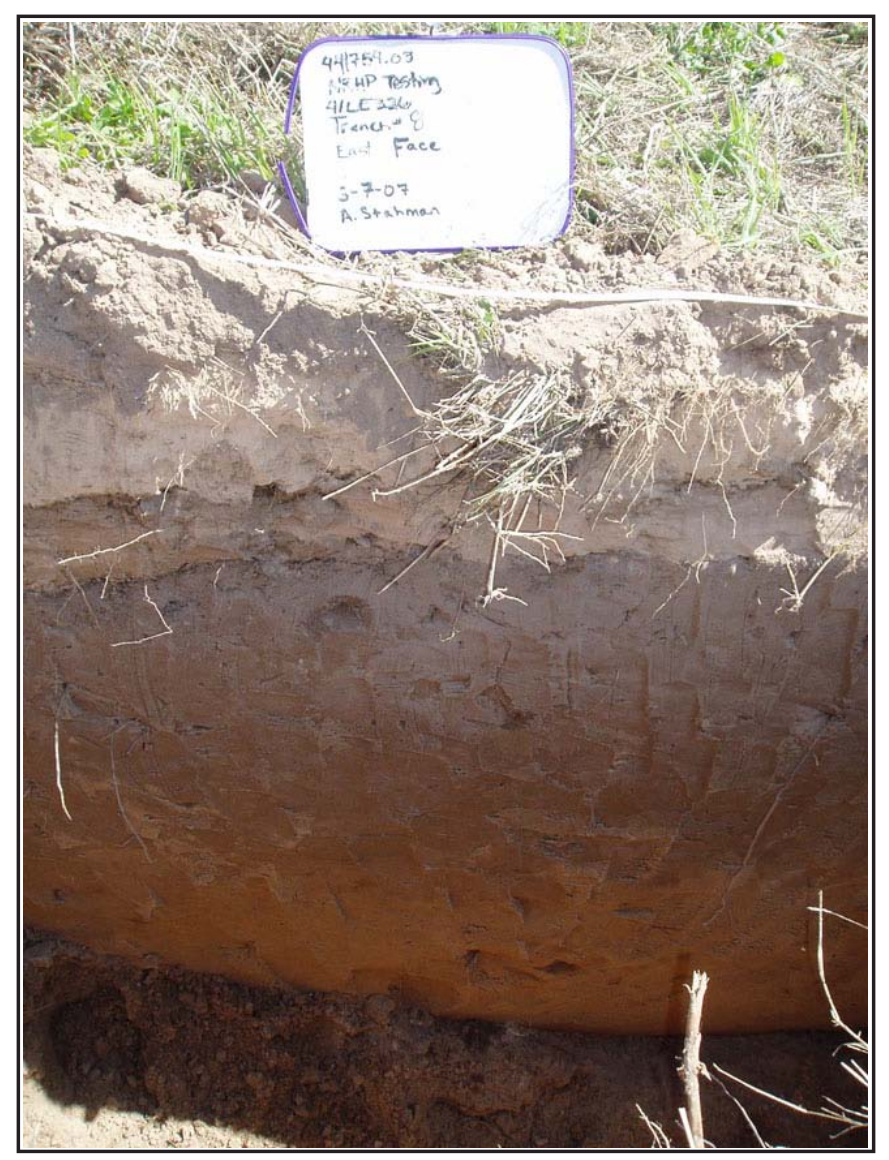

a) Section of profile, facing east.

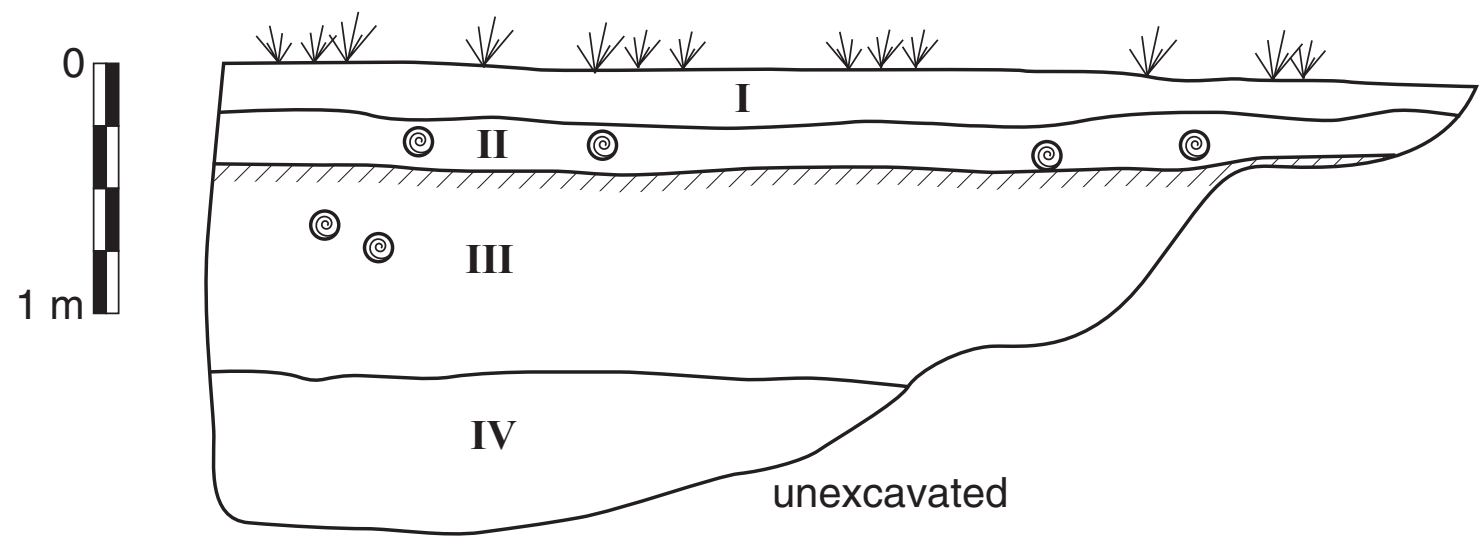

0

$1 \mathrm{~m}$

b) Profile of west wall.

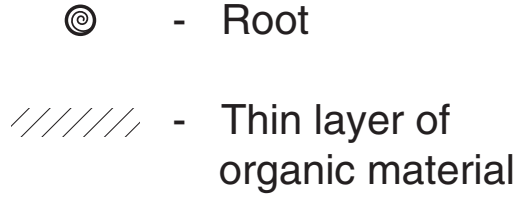

Note: No cultural materials were observed in the trench sidewalls.

\section{PBS\& - Environmental Consulting}

Figure 11

TRENCH NO. 8

WEST WALL PROFILE 


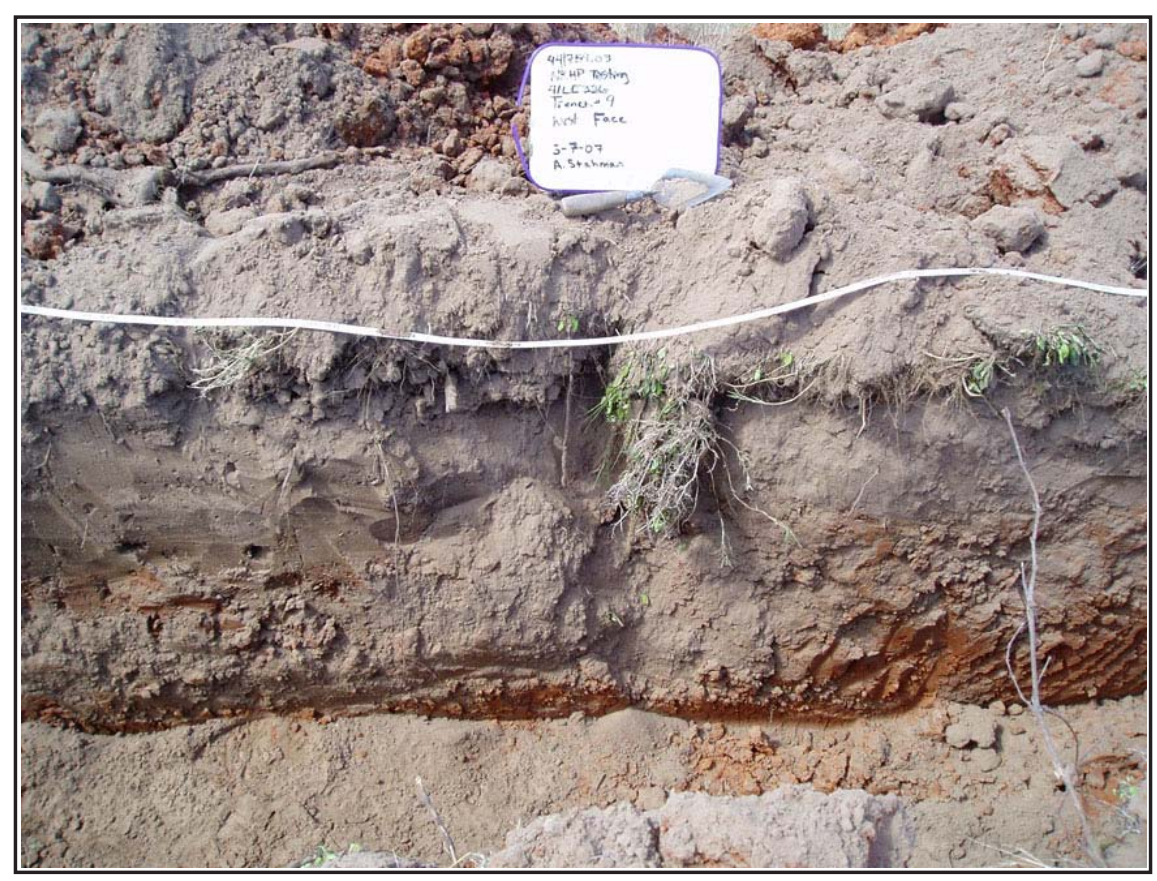

a) Section of profile, facing west.
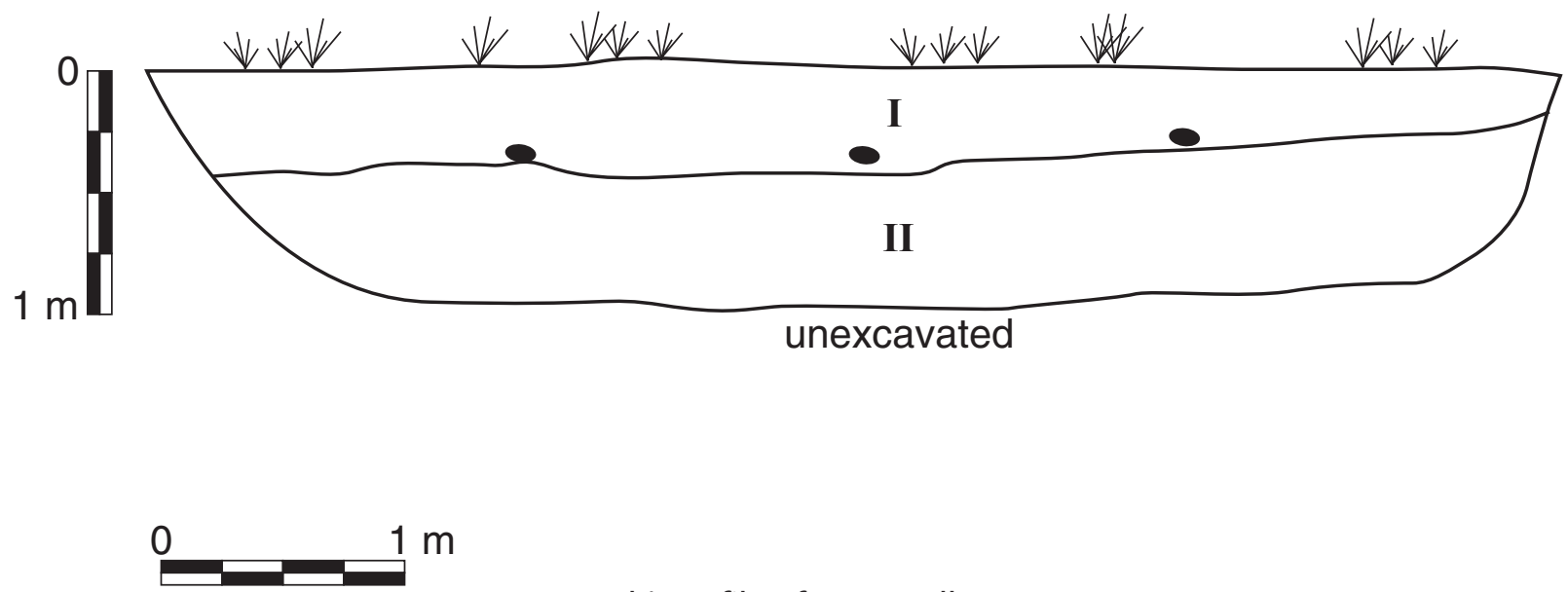

b) Profile of west wall.

- Rock (natural)

Note: No cultural materials were observed in the trench sidewalls.

\section{PBS\& • Environmental Consulting}

Figure 12

TRENCH NO. 9

WEST WALL PROFILE 
Table 2: Stratigraphic Profile, East Wall Trench 1

0-30 cm: Stratum I, A horizon; yellowish brown (10YR 5/4) fine sandy clay loam; very fine granular soil structure, friable consistency; common fine roots; few cobbles near bottom of stratum; abrupt, smooth boundary. No cultural materials observed.

24-30 cm: Stratum II, possible E horizon; very pale brown (10YR 7/4) fine sandy loam mottled with yellowish brown (10YR 5/4) fine sandy loam; very fine granular soil structure, friable consistency; no inclusions or roots; abrupt, clear boundary. No cultural materials observed.

30-76 cm (limit of exposure): Stratum III, Bt horizon; red (2.5YR 4/8) clay; platy soil structure, firm consistency; few small roots; no inclusions. No cultural materials observed.

Table 3: Stratigraphic Profile, East Wall Trench 2

0-25 cm: Stratum I, A horizon; yellowish brown (10YR 5/4) very fine sandy loam; very fine granular soil structure, friable consistency; many small roots; few small cobbles; abrupt, clear boundary. No cultural materials observed.

25-60 cm (limit of exposure): Stratum II, Bt horizon; red (2.5YR 4/8) clay; platy soil structure, firm consistency; few small roots mostly confined to upper $5 \mathrm{~cm}$ of this horizon; no inclusions. No cultural materials observed.

Table 4: Stratigraphic Profile, East Wall

Trench 3

0-200 cm (limit of exposure): Stratum I, A horizon; brownish yellow (10YR 6/6) very fine sandy loam; very fine granular soil structure, loose consistency; few rodent runs and small roots (mostly confined to upper $60 \mathrm{~cm}$ ); no inclusions. No cultural materials observed.

Table 5: Stratigraphic Profile, East Wall Trench 4

0-120 cm: Stratum I, A horizon; yellowish brown (10YR 5/4) fine sandy loam; fine granular structure, friable consistency; few small roots and few cobbles; abrupt, wavy boundary. No cultural materials observed.

120-123 cm: Stratum II, B horizon; dark reddish brown (5YR 3/4) clay loam; fine granular structure, friable consistency; no roots or inclusions; abrupt, wavy boundary. No cultural materials observed.

123-140 cm: Stratum III, E horizon; brownish yellow (10YR 6/6) fine sandy loam; fine granular structure, friable consistency; few small roots; abrupt, smooth boundary. No cultural materials observed.

140-190 cm (limit of exposure): Stratum IV, Bt horizon; strong brown (7.5YR 5/6) clay; platy soil structure, firm consistency, no roots or inclusions. No cultural materials observed. 
Table 6: Stratigraphic Profile, West Wall Trench 5

0-30 cm: Stratum I, A1 horizon; brownish yellow (10YR 6/8) clayey sand loam mottled with brownish yellow (10YR 6/6) clayey sand loam; granular soil structure, friable consistency; many pea-sized gravels; many small roots; few rodent runs; abrupt/clear, smooth boundary (stratum appears to be fill dirt that was redeposited during construction of US 77). No cultural materials observed.

30-125 cm: Stratum II, A2 horizon; yellowish brown (10YR 5/4) sandy loam; very fine granular soil structure, friable consistency; few pea-sized gravels; few large and small roots; few rodent runs; abrupt, smooth boundary. No cultural materials observed.

125-145 cm: Stratum III, B horizon; strong brown (7.5YR 5/8) sandy clay; coarse granular soil structure, very friable consistency; mottles of red (2.5YR 5/8) clay; common gravels; clear, wavy boundary. No cultural materials observed.

145-165 cm (limit of exposure): Stratum IV, C horizon; yellow (10YR 7/8) sandy loam; granular soil structure, loose consistency; few small gravels. No cultural materials observed.

Table 7: Stratigraphic Profile, East Wall, Trench 6

0-300 cm (limit of exposure): Stratum I, A horizon; yellowish brown (10YR 5/4) fine sandy loam; very fine granular soil structure, friable consistency; few medium to small roots; no inclusions (bottom of trench is just beginning to encounter red clay). No cultural materials observed.

Table 8: Stratigraphic Profile, West Wall Trench 7

0-40 cm: Stratum I, A horizon; dark yellowish brown (10YR 4/6) fine sandy loam; very fine granular soil structure, friable consistency; very few small roots; no inclusions; abrupt, smooth boundary (possibly redeposited soil from driveway excavation). No cultural materials observed.

40-110 cm (limit of exposure): Stratum II, Ab horizon; dark yellowish brown (10YR 4/4) fine sandy loam; very fine granular soil structure, friable consistency; few small roots; no inclusions. No cultural materials observed. 
Table 9: Stratigraphic Profile, West Wall Trench 8

0-10 cm: Stratum I, A1 horizon; yellow (10YR 7/6) very fine sandy loam; very fine granular structure, friable consistency; few small roots and few cobbles; clear, smooth boundary (possibly redeposited soil from driveway excavation). No cultural materials observed.

10-20 cm: Stratum II, A2 horizon; yellow (10YR 7/6) fine sandy loam mottled with dark yellowish brown (10YR 4/4) sandy loam; very fine granular structure, friable consistency; few large roots and gravels; clear, smooth boundary (possibly redeposited soil from driveway excavation). No cultural materials observed.

20-120 cm: Stratum III, Ab horizon; dark yellowish brown (10YR 4/4) fine sandy loam; very fine granular structure, friable consistency; few small roots; no inclusions; gradual, smooth boundary. No cultural materials observed.

120-180 cm (limit of exposure): Stratum IV, E horizon; yellow (10YR 7/6) fine sand; very fine granular soil structure, loose consistency, no roots or inclusions. No cultural materials observed.

Table 10: Stratigraphic Profile, West Wall Trench 9

0-40 cm: Stratum I, A horizon; yellowish brown (10YR 5/4) fine sandy loam; very fine granular soil structure, friable consistency; many small roots; few small cobbles; abrupt, clear boundary. No cultural materials observed.

40-90 cm (limit of exposure): Stratum II, Bt horizon; red (2.5YR 4/8) clay; platy soil structure, firm consistency; very few small roots; few gravels. No cultural materials observed.

\section{SCRAPING}

Two areas on the east side of US 77, totaling approximately $55 \mathrm{~m}^{2}$, were scraped by the backhoe. Stratigraphic descriptions of sediments encountered in these areas are provided in tables 11 and 12 and illustrated on figures 13 and 14. One of the scraped areas was excavated atop the upper terrace, while the other was excavated in the northern toeslope of the upper terrace approximately $120 \mathrm{~m}$ south of Middle Yegua Creek. Soil within these areas was removed in shallow layers approximately $10 \mathrm{~cm}$ or less in thickness until sterile soil was encountered. No subsurface features were encountered within Scraped Area No. 1. Within Scraped Area No. 2, a sparse concentration of whole cobbles, fire-cracked cobbles, and debitage measuring approximately $2.5 \mathrm{~m}$ by $1.5 \mathrm{~m}$ was noted but not collected. The top of the concentration was encountered at the top of the red clay horizon at $43 \mathrm{cmbs}$ and extended 2 to $7 \mathrm{~cm}$ into the red clay horizon. Deposits within the concentration displayed no distinction from surrounding sediments in either color or texture. No charcoal or ash appeared among the cobbles. Based on evidence observed, this concentration lacks characteristics that would define it as a feature including lack of indications of in situ burning or organic accumulation, color or textural distinction from surrounding sediments, etc. Given this interpretation, the diffuse nature of the concentration, and very limited depth, no matrix was screened. 
Table 11: Stratigraphic Profile, West Wall

Scraped Area No. 1

0-20-40 cm: Stratum I, A horizon; yellowish brown (10YR 5/4) fine sandy loam; very fine granular soil structure, friable consistency; few small roots; few large gravels; wavy, clear boundary. No cultural materials observed.

20-40-50 cm (limit of exposure): Stratum II, Bt horizon; red (2.5YR 4/8) clay; platy soil structure, firm consistency; few small roots; no obvious inclusions. No cultural materials observed.

Table 12: Stratigraphic Profile, West Wall

Scraped Area No. 2

0-40 cm: Stratum I, A horizon; yellowish brown (10YR 5/4) fine sandy loam; very fine granular soil structure, friable consistency; few small roots; no obvious inclusions; abrupt, clear boundary. No cultural materials observed.

40-50 cm (limit of exposure): Stratum II, Bt horizon; red (2.5YR 4/8) clay; platy soil structure, firm consistency; few small roots; many cobbles. A diffuse concentration of whole cobbles, fire-cracked cobbles, and lithic flakes was observed at the top of this stratum. Aside from this, no other cultural materials were observed.

\section{TEST UNITS}

Four 1-x-1-m test units were excavated during the testing program (see Figure 2). Test units were placed in areas that backhoe trenches and shovel tests suggested contained the greatest stratigraphic integrity and greatest density of subsurface artifacts. Since no cultural features appeared in any of the excavated trenches, excavation of these units was designed to reveal the finer indications of a buried cultural surface. All test units were excavated atop the upper terrace except for Test Unit 4, which was excavated along the terrace's northern toeslope near Scraped Area No. 2. The stratigraphy of these four units is represented in tables 13 through 16 and illustrated on figures 15 through 18.

Test Units 1 and 2 were excavated on the west side of US 77. The stratigraphic profiles of the two units were virtually identical with two strata of sandy loam above a red-orange clay horizon. Bioturbation from rodents and roots was encountered to a depth of between 30 and 40 cmbs. Modern glass was encountered in Test Unit 2 to a depth of $40 \mathrm{cmbs}$ and appears to indicate disturbance of sediments in this location. Test Unit 1 yielded a total of 319 artifacts consisting of 5 unifacially modified flakes, 3 utilized flakes, 3 cores, 197 pieces of lithic debitage, 109 pieces of fire-cracked rock, and 2 burned rocks. Test Unit 2 yielded a total of 20 prehistoric artifacts consisting of 16 pieces of lithic debitage, 2 cores, and 2 pieces of burned clay. Both units exhibited significant decreases in artifacts in Level 5, where a clay substratum was encountered. No features were encountered in these units. 


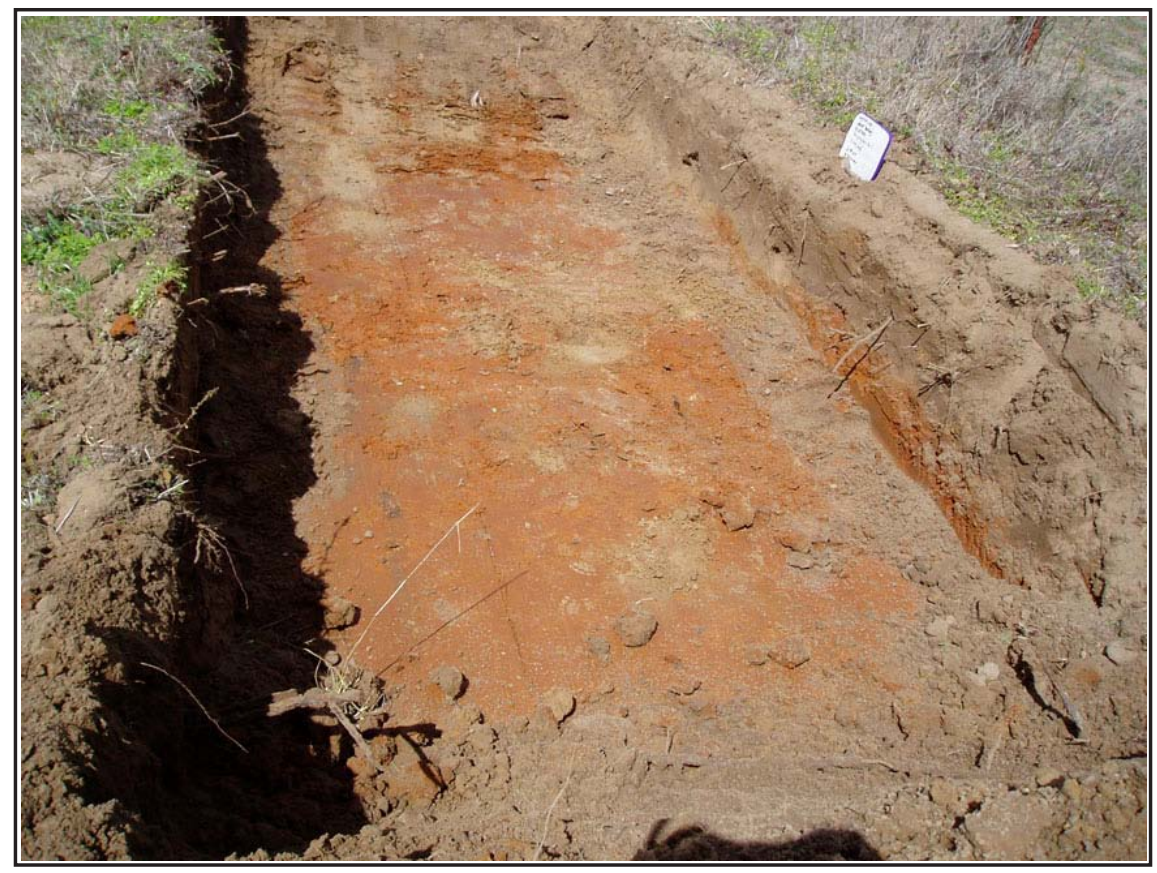

a) View of Scraped Area No. 1, facing north.
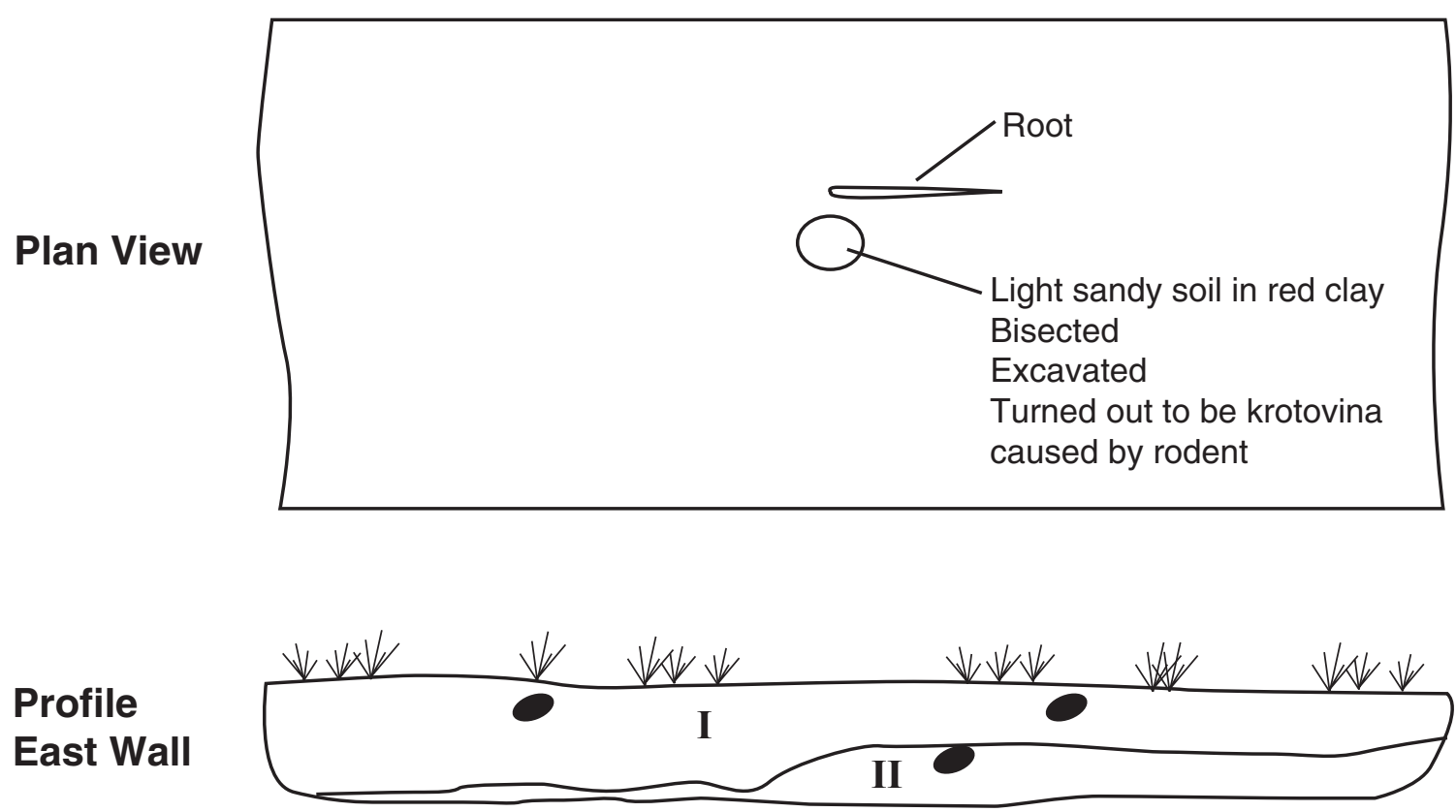

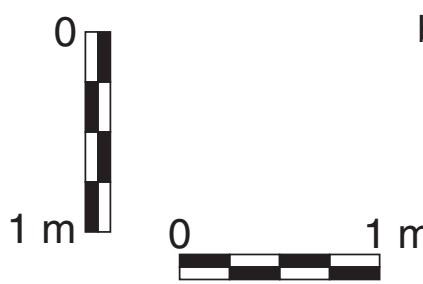

- Rock (natural)

b) Plan view and profile of Scraped Area No. 1.

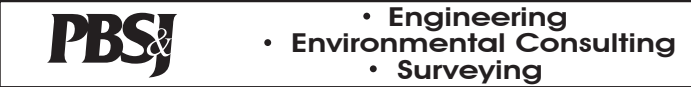

Figure 13

SCRAPED AREA NO. 1 


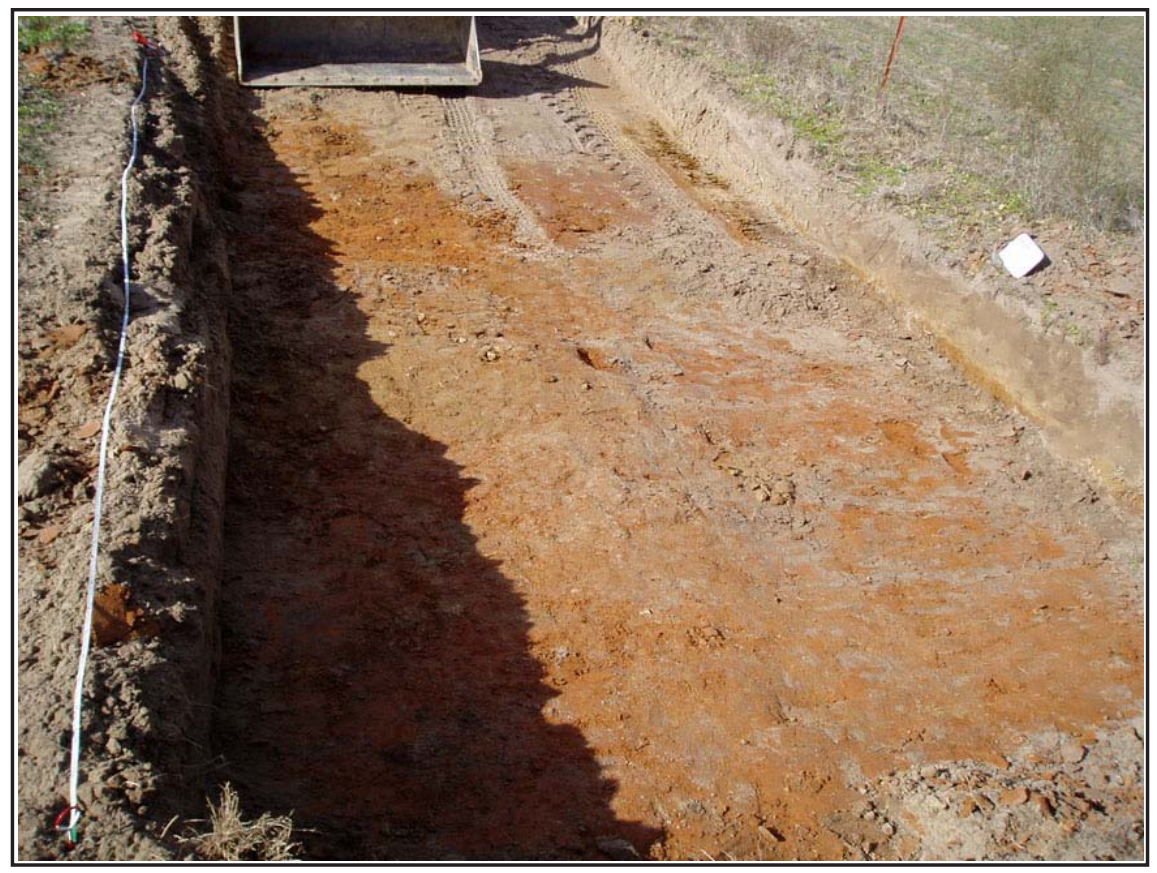

a) View of Scraped Area No. 2, facing north.

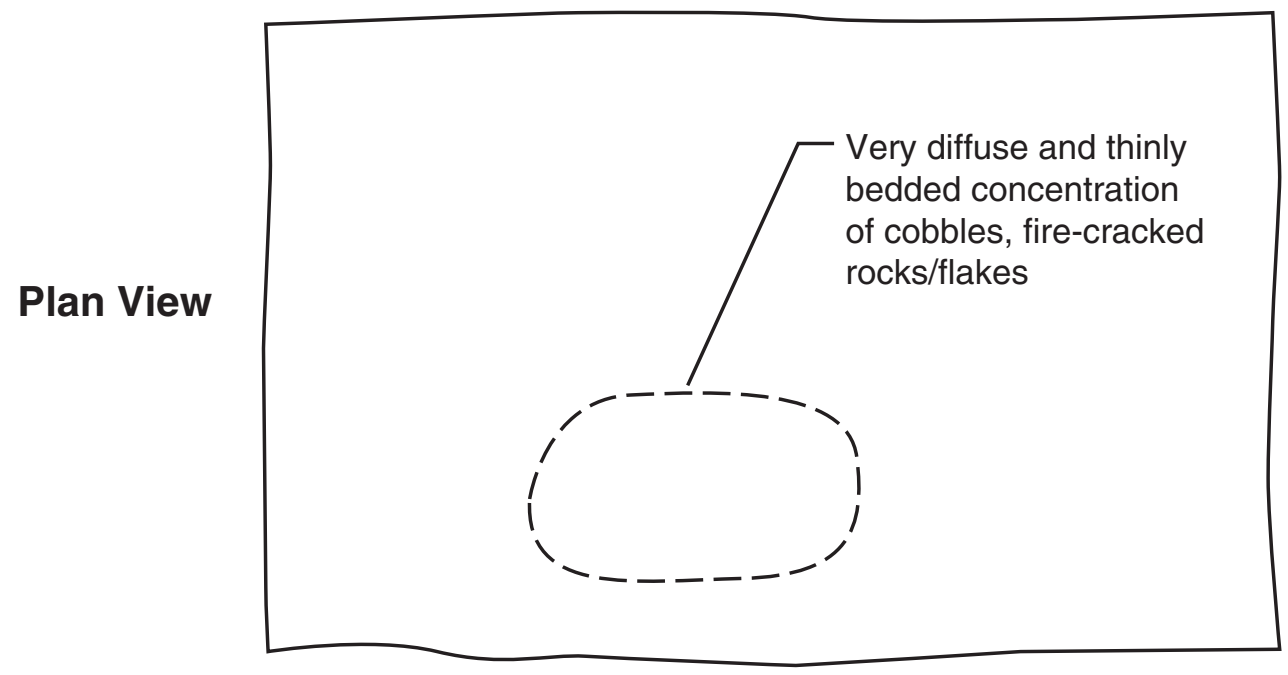

Profile East Wall

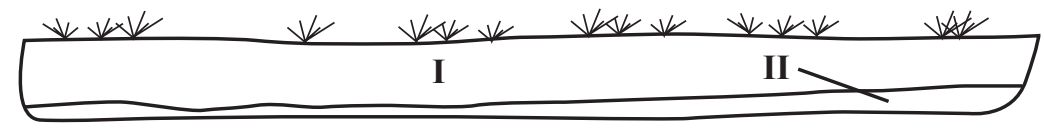

b) Plan view and profile of Scraped Area No. 2.
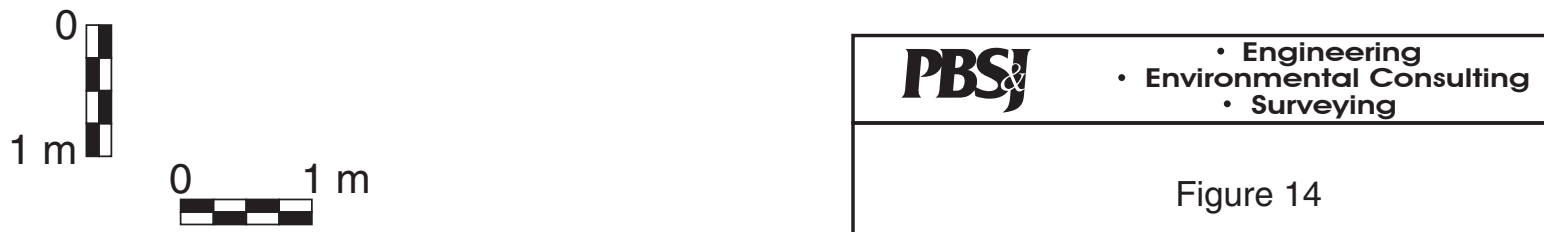

Figure 14

SCRAPED AREA NO. 2 
Table 13: Stratigraphic Profile, South Wall

Test Unit 1

0-40 cmbs (23-63 centimeters below datum [cmbd]): Stratum I, Ap horizon; dark yellowish brown (10YR 4/4) fine sandy loam; very fine granular soil structure; friable consistency; faint mottled inclusion (10YR 5/4); one rodent run, few small roots; abrupt boundary. A total of 192 lithic artifacts and 102 thermally altered rocks were recovered.

40-50 cmbs (63-73 cmbd): Stratum II, A horizon; yellowish brown (10YR 5/4) fine sandy loam; very fine granular soil structure; friable consistency; few small cobbles; one rodent run; few small roots; abrupt boundary. Artifact density decreases throughout this stratum and density of gravels increases. A total of 9 lithic artifacts and 8 thermally altered rocks were recovered.

50-60 cmbs (73-83 cmbd): Stratum III, Bt horizon; red (2.5YR 4/8) clay; platy soil structure; firm consistency. A total of 7 lithic artifacts and 1 thermally altered rock were recovered. Excavation terminated due to encounter with clay subsoil.

Table 14: Stratigraphic Profile, South Wall Test Unit 2

0-40 cmbs (20-60 cmbd): Stratum I, Ap horizon; pale brown (10YR 6/3) fine sandy loam; very fine granular soil structure; friable consistency; few small roots; few small cobbles, abrupt boundary. Significant increase in cobbles and large roots near base of stratum. A total of 18 lithic artifacts, 1 glass artifact, and 1 piece of burned matrix were recovered.

40-45 cmbs (60-65 cmbd): Stratum II, A horizon; yellowish brown (10YR 5/4) fine sandy loam; very fine granular soil structure; friable consistency; few small roots; abrupt boundary. Dramatic decrease in artifact count; only one piece of burned matrix was recovered.

45-55 cmbs (65-75 cmbd): Stratum III, Bt horizon; red (2.5YR 4/6) clay; platy soil structure; firm consistency; no inclusions, no artifacts observed. Excavation terminated due to encounter with clay subsoil.

Table 15: Stratigraphic Profile, South Wall Test Unit 3

0-110 cmbs (10-120 cmbd): Stratum I, Ap horizon; pale brown (10YR 6/3) fine sandy loam; very fine granular soil structure; very friable consistency; common medium to small roots; few small cobbles. A few larger roots and krotovina also present. Slight increase in gravel density around $30 \mathrm{cmbs}$, but this quickly decreases with next level. Modern fence staple observed at $50 \mathrm{cmbs}$. One burned glass shard was also collected at 80-90 cmbs. Dramatic increase in artifact density between 90 and $100 \mathrm{cmbs}$. Artifacts decrease with subsequent level. A total of 206 lithic artifacts, 87 fire-cracked rocks, and 1 charcoal sample were recovered. Excavation terminated due to safety hazard for excavators at this depth.

Table 16: Stratigraphic Profile, South Wall

Test Unit 4

0-36 cmbs (20-56 cmbd): Stratum I, Ap horizon; pale brown (10YR 6/3) fine sandy loam; very fine granular soil structure; friable consistency; few rodent runs; abrupt, wavy boundary. Numerous concretions in this stratum. A fence staple and barbed wire fragment were noted within the upper $10 \mathrm{cmbs}$. A total of 39 lithic artifacts and 10 fire-cracked rocks were recovered.

36-45 cmbs (56-65 cmbd): Stratum II, A horizon; very pale brown (10YR 7/4) fine sandy loam; very fine granular soil structure; friable consistency; few small roots; abrupt, wavy boundary. Few concretions in this stratum. A total of 4 lithic artifacts, 5 fire-cracked rocks, and 1 piece of burned matrix likely associated with burned roots from the level above were collected.

45-55 cmbs (65-75 cmbd): Stratum III, Bt horizon; yellowish red (5YR 5/8) clay; platy soil structure; firm consistency; no inclusions. Few concretions in this stratum. A total of 1 lithic artifact and 2 fire-cracked rocks were recovered. Excavation terminated due to encountered with clay subsoil. 


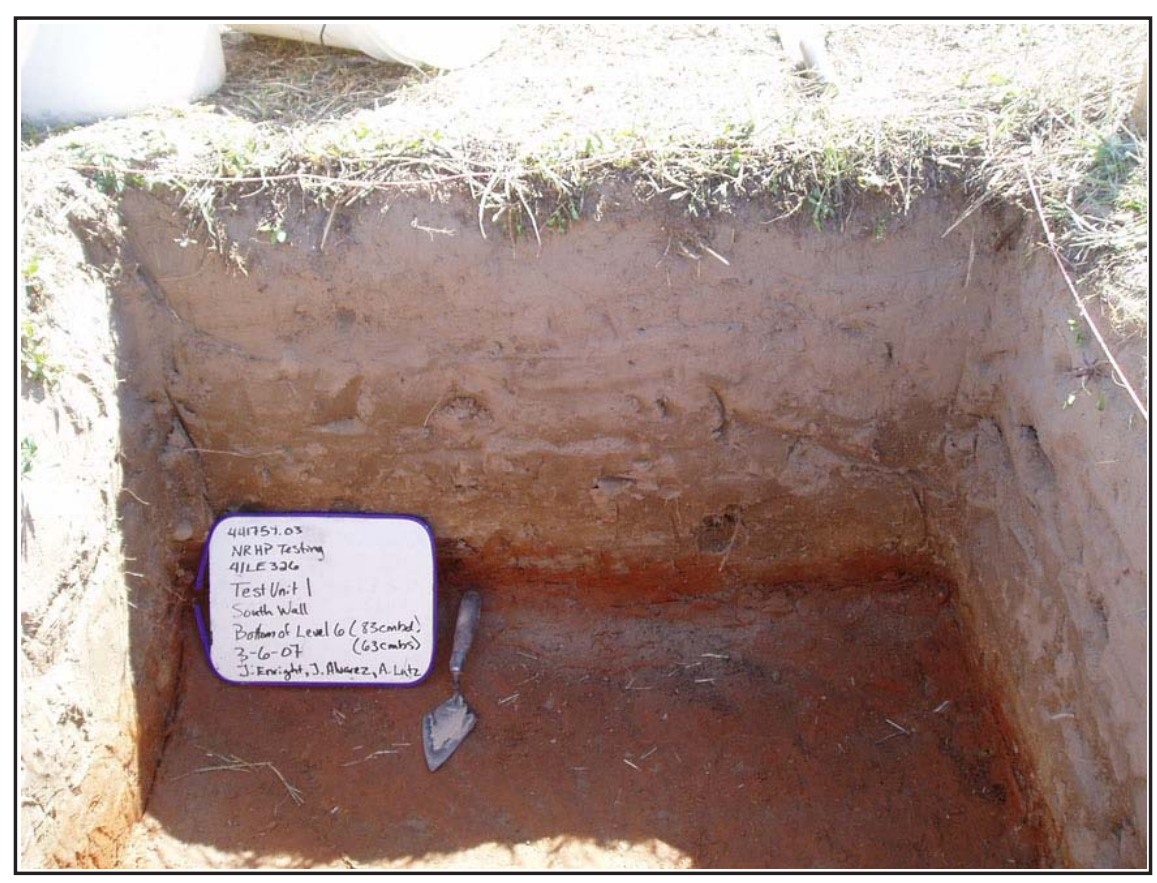

a) Profile, facing south (bottom of excavation).
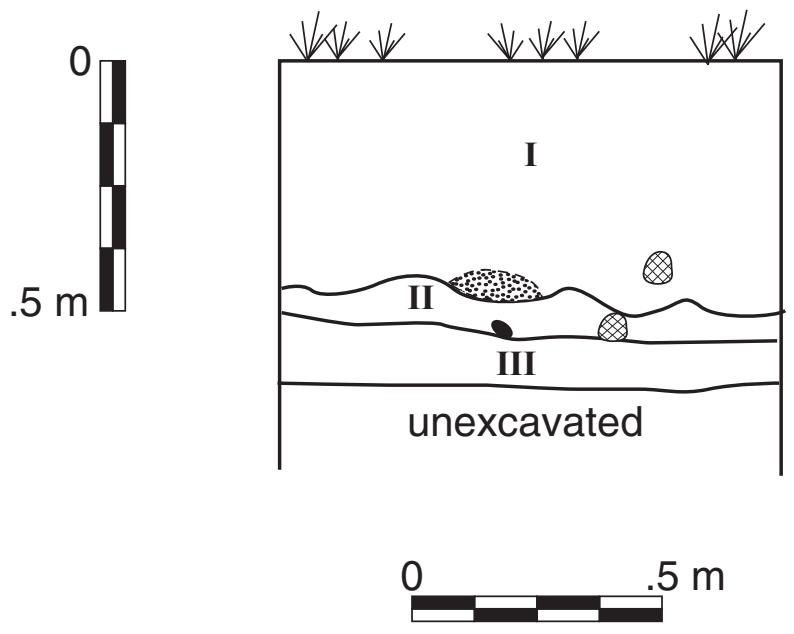

b) Profile of south wall.

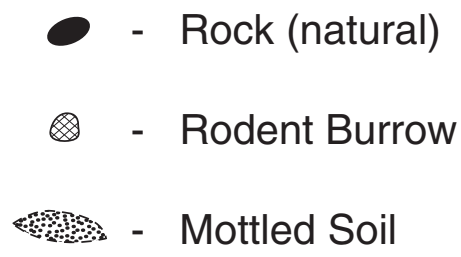
PBS\& - Environmental Consulting

Figure 15

TEST UNIT 1

SOUTH WALL PROFILE 


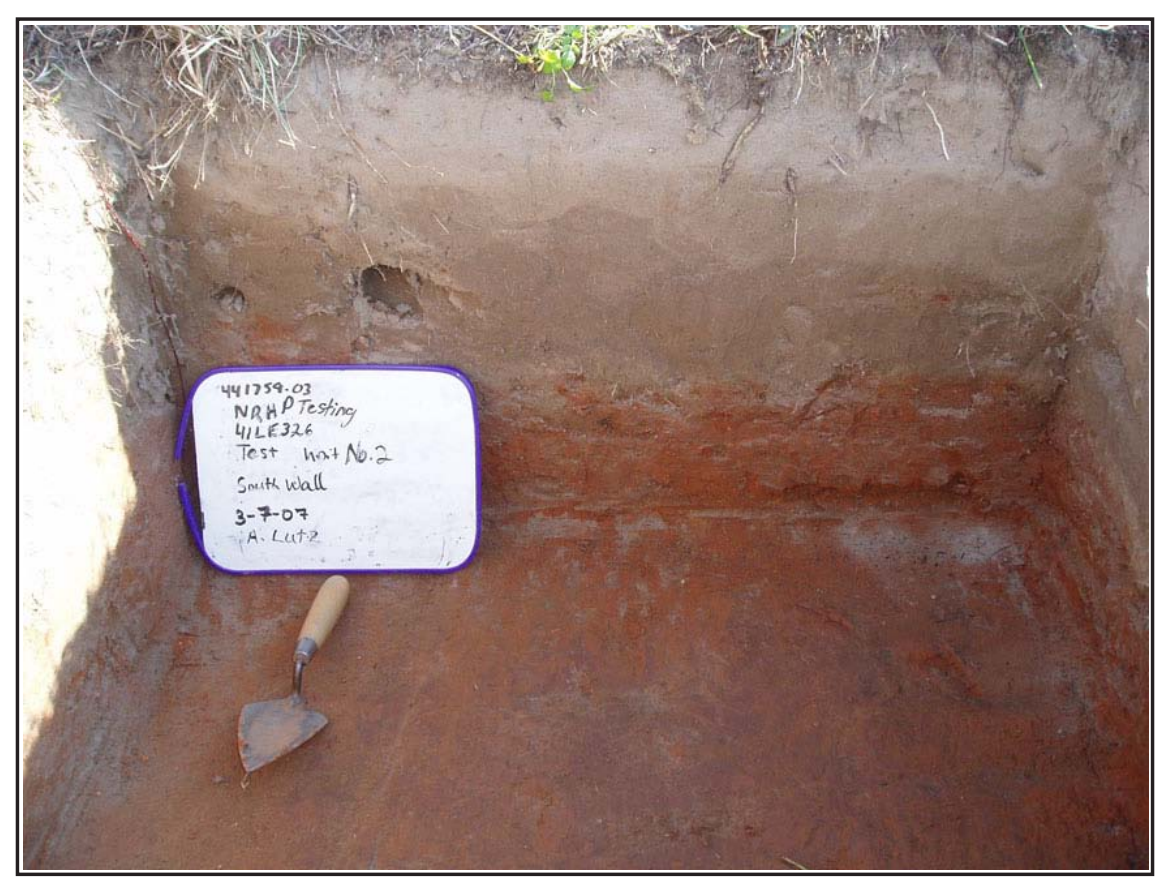

a) Profile, facing south.

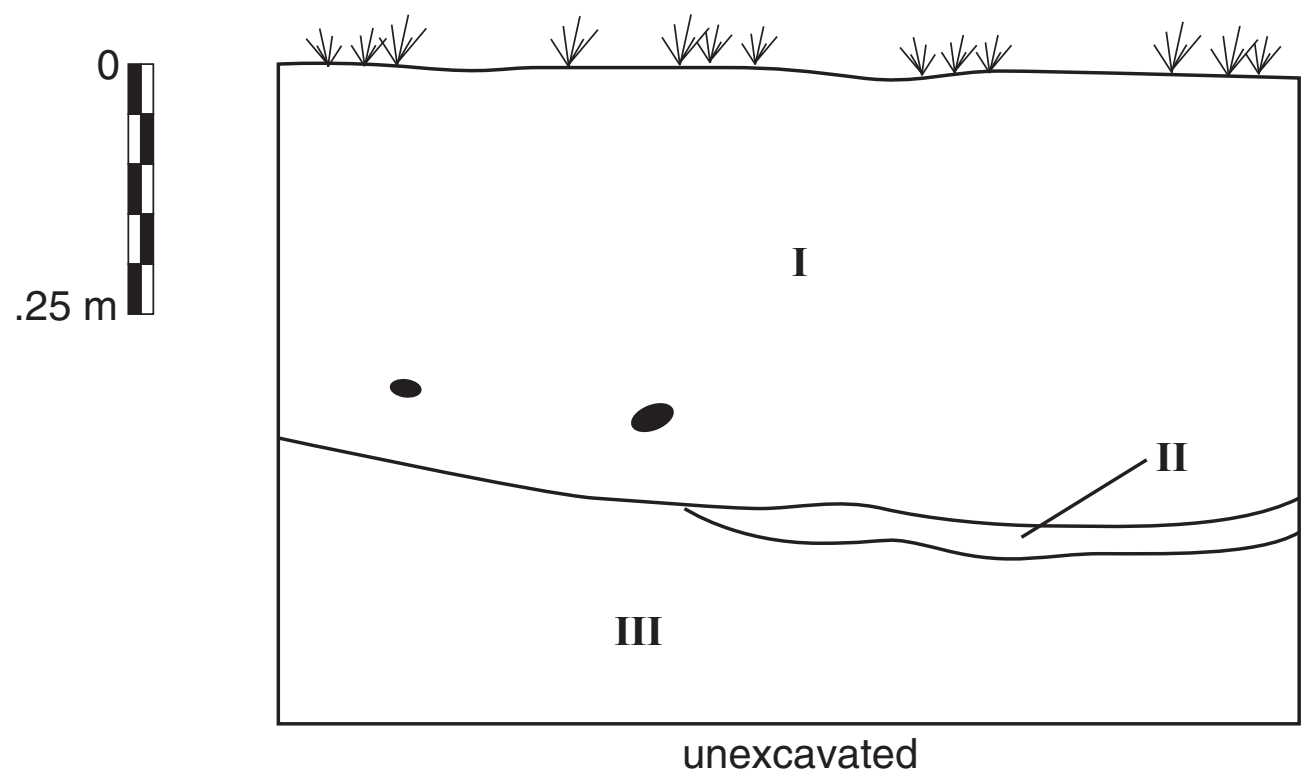

b) Profile of south wall.

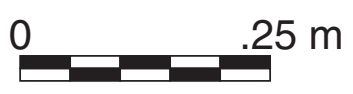
PBS\& $\begin{gathered}\bullet \text { Engineering } \\ \text { Environmental Consulting }\end{gathered}$

Figure 16

TEST UNIT 2

SOUTH WALL PROFILE 


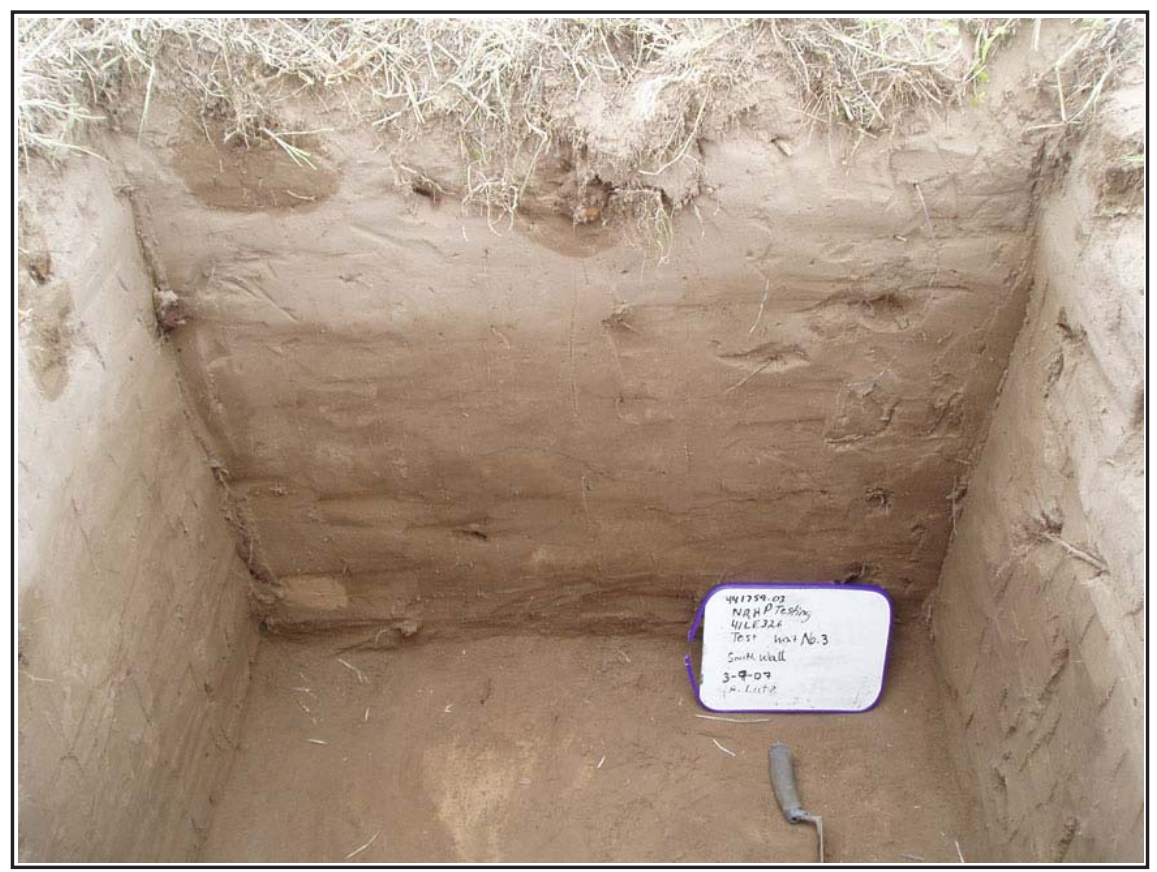

a) Profile, facing south.

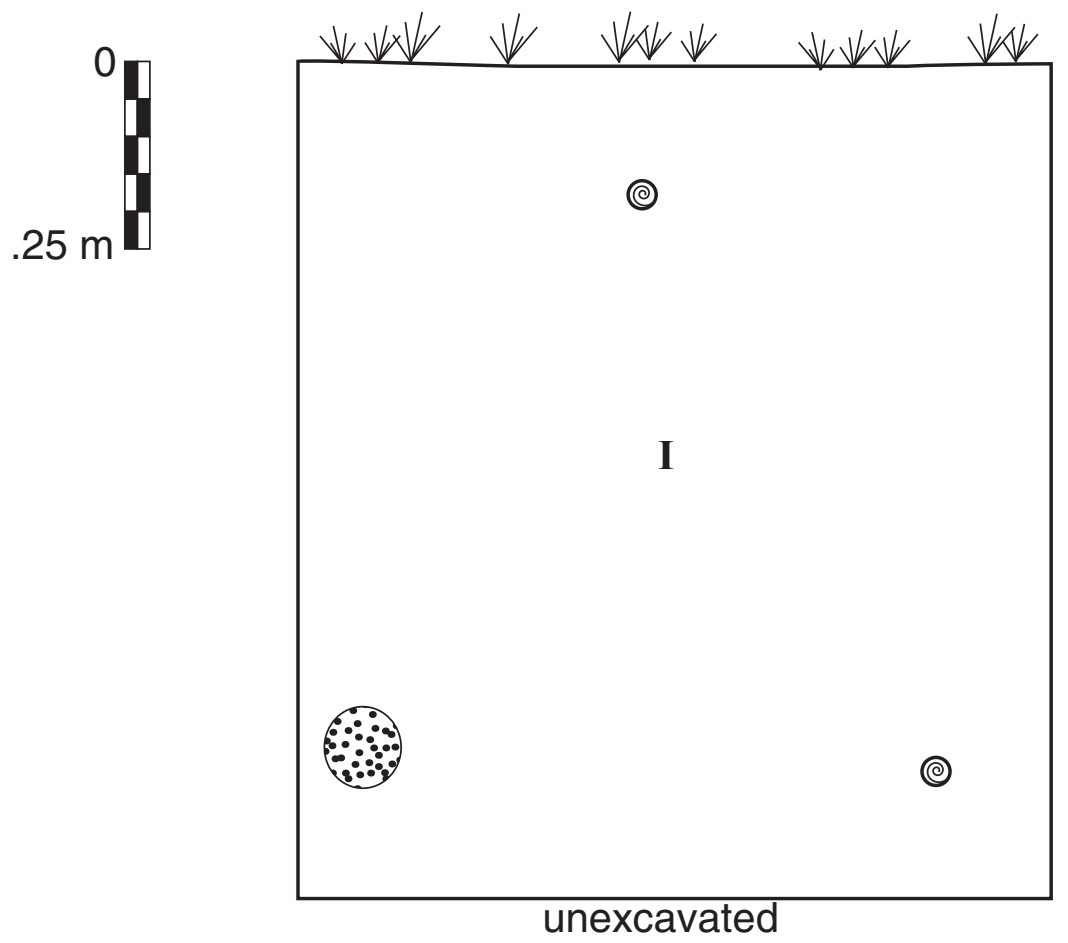

b) Profile of south wall.

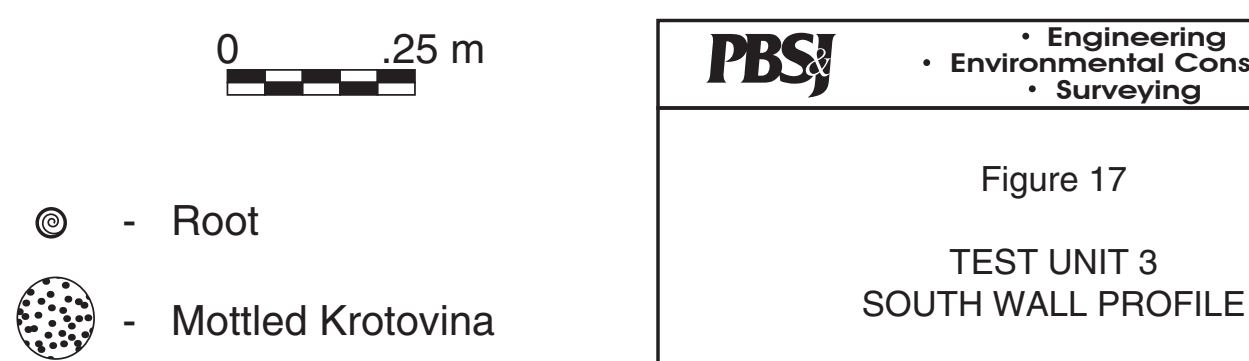




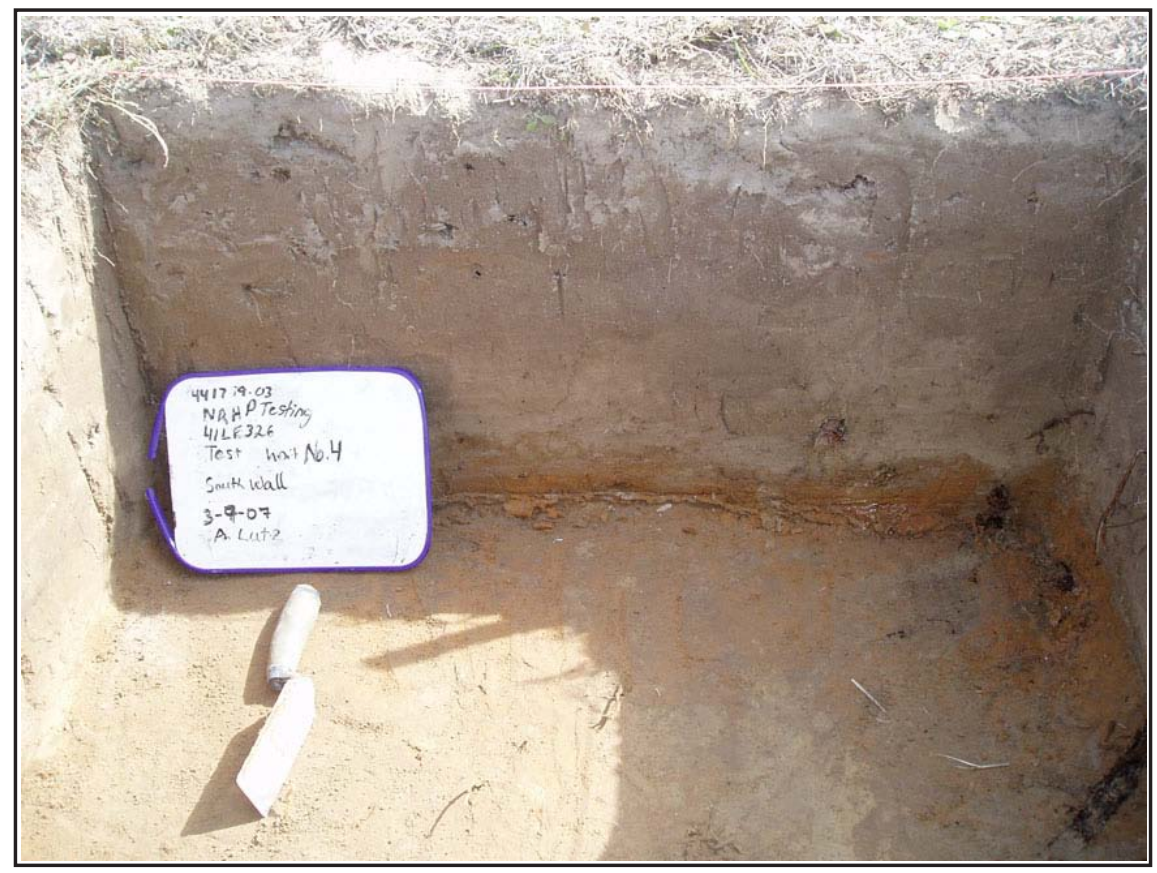

a) Profile, facing south.

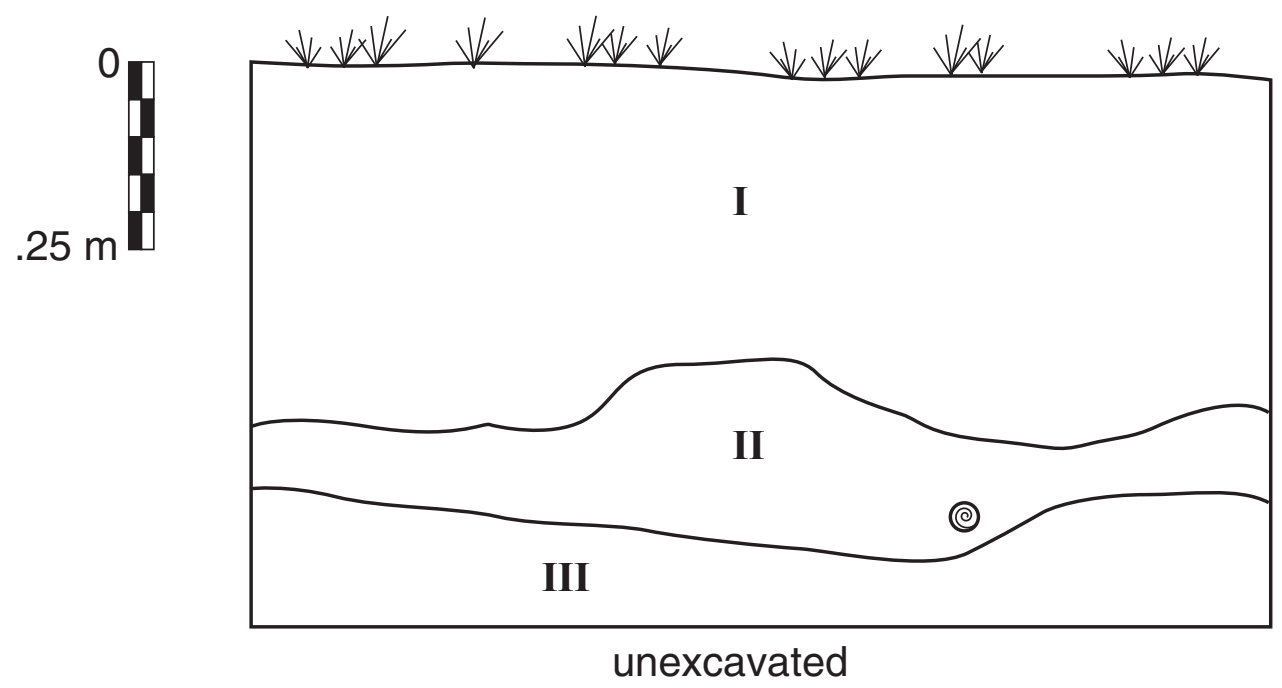

b) Profile of south wall.

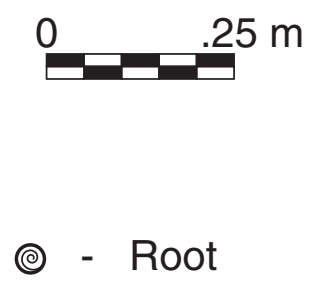
PRS Engineering - Environmental Consulting Surveying

Figure 18

TEST UNIT 4

SOUTH WALL PROFILE 
Test Unit 3 was excavated atop the upper terrace on the west side of US 77, north of Trench 8. Strata within Test Unit 3 consisted of a uniform A horizon of light brown very fine sandy loam, which continued until excavation of the unit was suspended at $110 \mathrm{cmbs}$. A total of 206 lithic artifacts consisting of 1 Pedernales dart point, 1 uniface, 1 unifacially modified flake, 2 utilized flakes, and 201 pieces of debitage, along with 87 fire-cracked rocks, 1 charcoal sample, and 1 burned glass shard were collected from Test Unit 3. One modern fence staple was noted but not collected from $50 \mathrm{cmbs}$ in Test Unit 3 and appears to indicate disturbance of the sediments in this location. Bioturbation from rodents and small to medium-sized roots was noted throughout the excavated unit. Artifact density in Test Unit 3 was highest in Level 10 (90-100 cmbs) with 64 artifacts, including the Pedernales point and the uniface.

Test Unit 4 was excavated in the upper terrace toeslope north of Scraped Area No. 2. Strata within Test Unit 4 appeared consistent with those of test units 1 and 2 (see tables 12 and 13). Bioturbation from small roots was noted throughout the excavated unit. A total of 42 pieces of lithic debitage, 1 Perdiz arrow point, 1 utilized flake, 17 fire-cracked rocks, and 1 piece of burned matrix were collected from Test Unit 4. The Perdiz arrow point was recovered from Level 3 (20-30 cmbs). Artifact density throughout the levels of this unit was rather low, less than 20 artifacts per level, which decreased significantly once clay was encountered.

All hand-excavated units were excavated in $10-\mathrm{cm}$ levels, and the fill was screened through $0.63-\mathrm{cm}$ screens (1/4-inch hardware cloth). All recovered cultural materials were bagged according to level. A total of 697 artifacts consisting of 15 lithic tools, 5 lithic cores, 456 pieces of lithic debitage, 215 thermally altered rocks, 2 shards of glass, and 3 pieces of burned matrix were recovered from the 1-x-1-m test units (see Appendix B). In addition, 0.40 gram (g) of charcoal was collected. Artifacts were recovered from the surface to a depth of 110 cmbs.

Results of the test unit excavations indicate that although prehistoric cultural materials are present, subsurface bioturbation from roots and burrowing animals has displaced artifacts to a considerable depth. Such evidence includes the shard of modern glass found in Test Unit 2 at $40 \mathrm{cmbs}$, the modern glass found in Test Unit 3 at 80-90 cmbs, and the modern metal fence staple found in Test Unit 3 at $50 \mathrm{cmbs}$. Additional root disturbances and rodent runs were found to depths of over $1 \mathrm{~m}$. This observation offers strong evidence for a lack of in situ prehistoric deposits within the portion of 41LE326 that lies within the APE.

\section{ARTIFACTS}

A total of 768 prehistoric artifacts were collected during testing at 41LE326, including 22 lithic tools, 503 pieces of lithic manufacturing debris, 3 pieces of burned matrix, and 239 pieces of thermally altered rock. In addition, $0.40 \mathrm{~g}$ of charcoal was recovered from the site (see Appendix B). Lithic tools included 1 Perdiz (Late Prehistoric period, ca. A.D. 1500-1200) arrow point (Test Unit 4, Level 3), 1 stem fragment of a Pedernales (Middle Archaic, ca. 2000-1200 B.C.) dart point (Test Unit 3, Level 10), 1 stem fragment of a Bulverde (Early Archaic, ca. 3000-2500 B.C.) dart point (ST 5, Level 1) (Turner and Hester 1999), 2 
unifaces (Test Unit 3, Level 10 and Test Unit 3, Level 7), 1 ground stone abrader fragment, 9 unifacially modified flakes, and 7 utilized flakes (Figure 19).

Analysis of the stone artifacts recovered from site 41LE326 followed a three-step process: (1) compilation of an initial inventory identifying basic artifact categories; (2) further classification and analysis of the artifacts; and (3) macroscopic examination of all tools to further identify any possible use-wear.

The lithic artifacts were initially divided into tools and nontools, with the former containing both chipped stone tools and ground stone tools, and the latter containing all forms of lithic manufacturing debris. All lithic materials were initially classified by raw material category.

\section{Analysis Methodology}

\section{Raw Material Type}

A total of 525 lithic specimens were recovered at site 41LE326 with the following material types having been recognized in the assemblage: chert $(n=520,99.05$ percent), hematitic sandstone $(n=1,0.19$ percent), macrocrystalline quartz $(n=2,0.38$ percent), and metaquartzite $(n=2,0.38$ percent). The properties of the individual material types are discussed in further detail below.

Quartz has a chemical formula $\mathrm{SiO}_{2}$ and is categorized in the mineral group of framework silicates in which every $\mathrm{O}^{2}$ atom is shared between two tetrahedra, forming a three-dimensional unit cell structure. The open framework system of quartz means that the mineral has a relatively low specific gravity of 2.65 and as a result is not stable at high pressures. Quartz does not exhibit cleavage, and the fracture patterns can be described as conchoidal. The mineral's hardness is 7 according to Moh's scale, and the streak on a ceramic plate is colorless. The color in a hand sample is commonly colorless to gray and the luster can be described as vitreous in nature (Nesse 2000).

Chert is a siliceous microcrystalline aggregate of quartz, which consists of granular microcrystalline quartz formed as nodules or discontinuous beds in limestone. Thus, the chemical formula remains $\mathrm{SiO}_{2}$ and the specific gravity is 2.65 . Chert has a hardness of 7, a colorless streak, a dull to waxy luster, and has a conchoidal or splintery fracture. The color in a hand sample is typically dark gray, light gray, graybrown, brown, or red, although a range of colors is possible depending on the percentage of impurity inclusions (Nesse 2000).

Metaquartzite is sandstone composed of more than 90 percent $\mathrm{SiO}_{2}$ and has been subjected to metamorphism under conditions of increased heat and pressure. The intergranular spaces of the metaquartzite have been filled as the intense tectonic conditions deformed the mineral grains and recrystallized the cementing agent forming a consolidated mass. Metaquartzite has a hardness of 7, a specific gravity range of 2.65-2.7, a colorless streak, and a waxy luster. The fracturing of quartzites is unique in that the specimen will break smoothly through the grains in a subconchoidal to conchoidal 


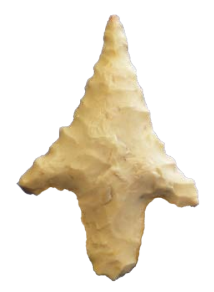

Lot 45.1

Perdiz Arrow Point

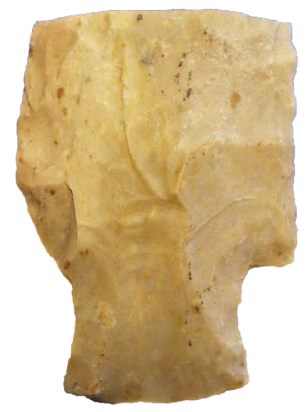

Lot 11.1

Bulverde Dart Point Fragment

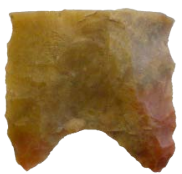

Lot 41.1 Pedernales Dart Point Fragment

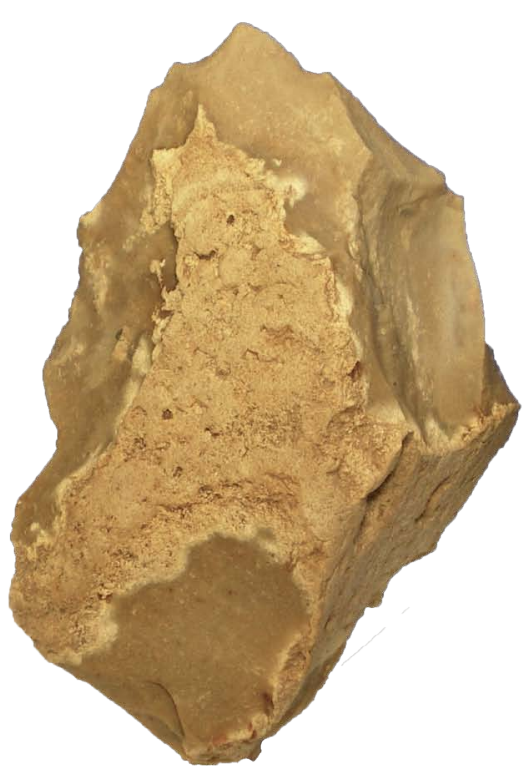

Lot 3.1

Uniface Fragment

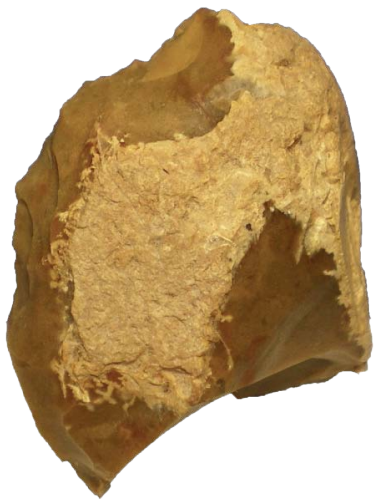

Lot 41.2 Uniface Fragment

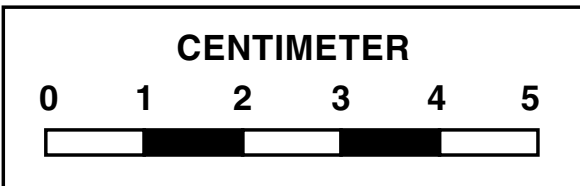

Drawn By: C. Wallace

I:|projects|he1/clients|txdot|441759/441759.03 testing at 41le326/cadlfigure19.pd 
manner. The color depends on the types of mineral inclusions and cementing agents. For example, a metaquartzite formed from the consolidation of quartz grains and quartz cement will be nearly white, while sandstone with quartz grains and hematitic cement will result in a brown to red or yellow specimen (Nesse 2000).

Hematitic sandstone is a composite of sand-sized quartz grains and contains hematite as the cementing agent. The hardness of the sample depends on the degree of compaction and cementation, with an upper range at approximately 6.5 on Moh's scale. The streak is a brown-yellow to brown-red, and the fracture can be described as irregular since a specimen will fracture around the quartz grains rather than across. The color is often brown-yellow to brown-red or dark red as the hematitic cement will also stain the surface of the quartz grains (Nesse 2000).

\section{Nontools}

Nontool materials recovered at 41LE326 consist of unmodified lithic debitage and cores. Nontool materials were further categorized by raw material and reduction. Each nontool category is discussed below.

Lithic debitage includes all unmodified, detached manufacturing debris. Artifact reduction for lithic debitage was considered from the following categories: primary flakes, secondary flakes, tertiary flakes, and chips. Primary flakes were defined as the initial flake removed from a core, thus retaining the exterior cortex on the dorsal side and a platform on the ventral side. Secondary flakes were defined as any flake that retained 1 to 99 percent of the cortex on the dorsal side. Tertiary flakes were defined as the interior flakes that did not retain any cortex. All other lithic debris was categorized as chips.

A core is defined as including any relatively large stone or cobble that shows negative flake scarring, resultant from intentional detachment. The reduction of cores can be either unidirectional or multidirectional, based upon the recognizable direction from which flakes are removed. Unidirectional cores have flakes removed in the same direction from a single point or area, whereas multidirectional cores have flakes removed in varying directions and from multiple points of applied force.

\section{Tools}

Tools recovered at 41LE326 are identified as chipped stone tools and ground stone tools, and were further categorized by raw material, tool type, reduction stage, form, and thermal alteration. Metric measurements, use-wear identification, and any additional tool specific attributes were recorded as well. All stone tools were further examined microscopically to identify possible use-wear.

Chipped stone tool types in the 41LE326 assemblage consist of arrow point, dart points, unifaces, unifacially modified flakes, and utilized flakes. A criterion for the determination of each type is identified below. 
Arrow points are identified as finely worked projectile points that are bifacially worked and contain a hafting element, allowing for attachment to an arrow shaft. The single arrow point recovered was classified by specific point typology.

Dart points appear as larger, bifacially worked projectile points with wide bases, moderate to fine thinning, and a hafting element, allowing for attachment to a spear. Such tools generally precede the use of arrow points; however, they may exhibit signs of being reworked and could have been reused during multiple occupation periods. Both recovered dart points were classified by specific point typology.

Unifaces were evaluated based upon suggested tool use. Such use was evaluated based upon overall thickness, level of thinning, and use-wear. Uniface specimens were not evaluated for stage due to the variety of uniface types that can occur. A larger sample would be necessary to best evaluate stage.

Unifacially modified flakes are identified as pieces of lithic debitage that exhibit intentional modification along one or more edges, with such modification often being evidenced by microchipping. Tools of this type often show evidence of wear along the modified edge, which can assist to further evaluate tool use. Reduction criterion utilized for unifacially modified flakes are the same as those used for unmodified debitage.

Utilized flakes are identified as pieces of lithic debitage that exhibit use-wear on one or more edges. Utilized flakes show no intentional modifications. Reduction criterion utilized for utilized flakes are the same as those used for unmodified debitage.

Ground and battered stone tools are generalized tools in the sense that a single tool may not be functionally specific with regard to the manner in which it is used or the things it is used to process or prepare. To systematically classify these tools it is important to use well-defined criteria for recognizing their diverse nature and possible function. Since a variety of processes can produce distinctive wear, tools were assigned to specific analytical categories on the basis of several key variables: the mechanical processes, the outcome of those processes, and the material being processed. Microscopic examination of the single ground stone tool aided in the identification of the key mechanical processes and the subsequent wear patterns still visible on the tool. Because any specific tool can be used in a range of activities, multifunctional tools are categorized on the basis of the predominant type of wear still visible on the tool.

\section{Thermal Alteration}

All lithic tools were examined for evidence of thermal alteration and whether they displayed evidence of having been intentionally or unintentionally heat treated. Thermal alteration was identified based upon the following attributes: color, luster, and fracturing. In particular, specimens exhibiting hues of red, increased luster, and/or fracture patterns consistent with such heat treatment were identified as being thermally altered. 
Intentional thermal alteration is observed in the form of color change, resulting in artifacts occurring in hues of red and with increased luster. Heated materials are easier to work and fracture more conchoidally than unheated specimens, as the point-tensile strength of the material is reduced upon heating caused by the fusing of impurities and microcrystals within a rock, thus allowing the material to fracture with less pressure and in a more even and conchoidal manner. This fusing also results in a surface that is more lustrous and evenly appearing (Purdy and Brooks 1971). Studies have shown that introducing the materials to controlled temperatures produces color change beginning at approximately 240 degrees Celsius $\left({ }^{\circ} \mathrm{C}\right)$, with increased luster and reduced tensile strength occurring generally between 350 and $400{ }^{\circ} \mathrm{C}$ (Purdy and Brooks 1971). Additional work by Frederick and Ringstaff (1994) in Bell and Coryell counties, Texas, has shown an increase in workability of chert, predominantly between temperatures of 330 and $460{ }^{\circ} \mathrm{C}$. These temperature range limits will vary somewhat slightly depending on the chemical makeup of the individual raw materials.

Unintentional heat alteration is suggested if the specimen exhibits the properties of intentional heat alteration along with abrupt fracturing and an increase in friability. This effect would be caused by exposing the specimens to much higher temperatures and for longer periods of time. All material types recovered at the site are comprised of quartz crystals, which undergo disintegrative effects at temperature in excess of about $575 \pm 2{ }^{\circ} \mathrm{C}$ (Rogers 1928). These effects can be reached at lower temperatures if the impurities in the raw material have lower temperature limits than that of the quartz. Any materials introduced directly to an open-air fire, such as those necessary for successful firing of pottery between 600 and $850{ }^{\circ} \mathrm{C}$, would exhibit such breakdown (Rice 1987). Therefore, specimens having hues of red or increased luster, along with the aforementioned fracturing, are identified as having been unintentionally heated.

\section{Lithic Analysis}

All lithic specimens were subject to the aforementioned analysis criteria. A total of 525 lithic artifacts were recovered at site 41LE326. Of the 525 specimens recovered, 22 are identified as tools and 503 are identified as nontools.

\section{Tool Analysis}

Tool types encountered at the site include arrow point $(n=1)$, dart point $(n=2)$, ground stone $(n=1)$, uniface $(n=2)$, unifacially modified flake $(n=9)$, and utilized flake $(n=7)$.

Arrow Point: The single arrow point recovered at the site, Lot 45.1, is identified as a complete chert Perdiz arrow point (see Figure 19). Metric attributes of this tool are listed in Table 17. This specimen has a triangular-shaped body, serrated recurved lateral edges, strong outflaring barbs, contracting stem, and a convex basal edge. The distal tip of this specimen has been additionally thinned and shows wear indicative of utilization as a drill. The Perdiz type was recovered at nearby related sites 41LE59 (Rogers and Kotter 1995) and 41LE57 (Rogers 1999) and indicates a Late Prehistoric occupation at the site. 
Table 17: Projectile Point Metric Attributes

\begin{tabular}{cccccccc}
\hline \hline Lot No. & Type & $\begin{array}{c}\text { Length } \\
(\mathrm{mm})\end{array}$ & $\begin{array}{c}\text { Width } \\
(\mathrm{mm})\end{array}$ & $\begin{array}{c}\text { Thickness } \\
(\mathrm{mm})\end{array}$ & $\begin{array}{c}\text { Stem Length } \\
(\mathrm{mm})\end{array}$ & $\begin{array}{c}\text { Neck } \\
(\mathrm{mm})\end{array}$ & $\begin{array}{c}\text { Weight } \\
(\mathrm{g})\end{array}$ \\
\hline 11.1 & Dart Point & 38.45 & 27.94 & 8.95 & 12.42 & 16.12 & 10.40 \\
41.1 & Dart Point & 16.55 & 17.72 & 6.52 & na & 17.33 & 2.01 \\
45.1 & Arrow Point & 25.98 & 17.39 & 4.42 & 8.01 & 6.23 & 0.89 \\
\hline
\end{tabular}

Dart Points: Only two dart points were recovered at 41LE326. These specimens are identified as Bulverde and Pedernales types. Metric attributes of these materials can be located in Table 17.

Lot 11.1 (see Figure 19) is identified as a proximal-medial fragment of a chert Bulverde dart point. This specimen has a triangular-shaped body, straight lateral edges, prominent squared shoulder, one snapped shoulder, expanding stem, slightly convex basal edge, and random flaking. This specimen exhibits the type's characteristic wedge-shaped base and is fractured at a material flaw. Wear along approximately 6.42 millimeters $(\mathrm{mm})$ of the straight lateral edge suggests use for scraping medium soft to medium-hard materials. The Bulverde type generally suggests an Early to Middle Archaic occupation (Bell 1960; Turner and Hester 1999).

Lot 41.1 (see Figure 19) is identified as a proximal fragment of an intentionally thermally altered chert Pedernales dart point. This specimen has a rectangular bifurcated stem thinned by removal of single flutelike flake on both faces. It exhibits a hinge fracture and shows no evidence of utilization, suggesting abandonment upon breaking. The Pedernales type generally suggests a Middle Archaic occupation (Turner and Hester 1999).

Both types were recovered at nearby 41LE59 (Rogers and Kotter 1995), and the Pedernales type was also recovered at nearby 41LE57 (Rogers 1999). While traditionally is has been suggested that these types represent the Middle Archaic, it has been noted that sites in the area containing both type traditions most likely represent a Late Archaic I occupation period (Johnson 1994b).

Ground Stone: One ground and battered stone artifact was recovered from ST 3, Level 8. Although postdepositional erosion had affected the stone, remnants of one or more wear patterns are still visible on the tool. Examination under 10x power binocular magnification revealed three types of wear: grinding, polishing, and grooving. Based on the observed wear patterns, the tool was classified as an abrader. The specimen appears to be the lateral end fragment of what was once a rectilinear-shaped grooved abrader. This heavily weathered fragment is made of coarse-grained hematitic sandstone and measures $57.16 \mathrm{~mm}$ in length, $32.6 \mathrm{~mm}$ in width, and $25.66 \mathrm{~mm}$ thickness. Deep grooves crosscut one plane surface and the unbroken end. Several shallow striations occur randomly along the face and two edges. Patches of grinding are still visible in the high relief areas, and there are distinct areas of polish at one end of the working face and along one edge. This type of wear points to nonfood-related activities such as the manufacture and maintenance of a variety of wood, stone, and/or possibly bone implements. 
Unifaces: The two unifaces recovered at the site are identified as chert flake side scrapers. These specimens are both proximal fragments of chert secondary flakes. Lot 3.1 (see Figure 19) is an ovateshaped specimen with a maximum length of $72.10 \mathrm{~mm}$, which shows intentional modification and wear along $14.82 \mathrm{~mm}$ of the concave lateral edge indicative of use for scraping medium-soft to medium-hard materials. Lot 41.2 (see Figure 19) is an ovate-shaped specimen with a maximum length of $48.03 \mathrm{~mm}$, which shows intentional modification and wear along $34.49 \mathrm{~mm}$ of the convex distal edge indicative of use for scraping medium-soft materials.

Unifacially Modified Flakes: Unifacially modified flakes are the most frequent tool type recovered at the site, accounting for approximately 41 percent of the tool assemblage $(n=9)$. The basic attributes of these materials are recorded in Table 18. Based upon wear patterns observed, it is suggested that these expedient tools were utilized for multiple activities including cutting, planing, sawing, and scraping. Both cutting and sawing activities require that the flake be held with the working edge parallel to the direction of use. The difference between the two is that sawing is generally used on harder materials such as bone or wood (Keeley 1980). Both planing and scraping activities involve the flake being held with the working edge approximately at a right angle to the direction of use; however, with planing the flake edge is pushed, while with scraping the flake edge is pulled (Keeley 1980).

Table 18: Unifacially Modified Flake Attributes

\begin{tabular}{|c|c|c|c|c|c|c|c|c|}
\hline $\begin{array}{l}\text { Lot } \\
\text { No. }\end{array}$ & Material & $\begin{array}{l}\text { Modified } \\
\text { Edge } \\
(\mathrm{mm})\end{array}$ & $\begin{array}{l}\text { Modified Edge } \\
\text { Shape/Location }\end{array}$ & Utilization & Use Material & $\begin{array}{l}\text { Reduction } \\
\text { Type }\end{array}$ & Form & $\begin{array}{c}\text { Thermal } \\
\text { Alteration }\end{array}$ \\
\hline 2.1 & Chert & 10.56 & Recurved/Distal & Scraping & Medium soft & $\begin{array}{l}\text { Secondary } \\
\text { Flake }\end{array}$ & $\begin{array}{l}\text { Proximal } \\
\text { Fragment }\end{array}$ & Intentional \\
\hline 11.2 & Chert & 12.07 & Concave/Distal & Cutting & Medium soft & $\begin{array}{l}\text { Tertiary } \\
\text { Flake }\end{array}$ & $\begin{array}{l}\text { Distal } \\
\text { Fragment }\end{array}$ & None \\
\hline 20.1 & Chert & 13.15 & $\begin{array}{l}\text { Slightly Convex/ } \\
\text { Distal }\end{array}$ & Cutting & Soft & $\begin{array}{l}\text { Tertiary } \\
\text { Flake }\end{array}$ & Complete & Intentional \\
\hline 22.1 & Chert & 17.87 & Straight/Lateral & Planing & Medium hard & $\begin{array}{l}\text { Tertiary } \\
\text { Flake }\end{array}$ & $\begin{array}{l}\text { Distal } \\
\text { Fragment }\end{array}$ & None \\
\hline 22.2 & Chert & 5.52 & $\begin{array}{l}\text { Straight/Broken } \\
\text { Lateral }\end{array}$ & Planing & $\begin{array}{l}\text { Soft to } \\
\text { medium soft }\end{array}$ & $\begin{array}{l}\text { Tertiary } \\
\text { Flake }\end{array}$ & $\begin{array}{l}\text { Distal } \\
\text { Fragment }\end{array}$ & Intentional \\
\hline 23.1 & Chert & 14.88 & Straight/Lateral & Scraping & Soft & $\begin{array}{l}\text { Secondary } \\
\text { Flake }\end{array}$ & $\begin{array}{l}\text { Proximal } \\
\text { Fragment }\end{array}$ & None \\
\hline 23.2 & Chert & 15.22 & Straight/Proximal & Planing & $\begin{array}{l}\text { Medium soft } \\
\text { to medium } \\
\text { hard }\end{array}$ & $\begin{array}{l}\text { Tertiary } \\
\text { Flake }\end{array}$ & $\begin{array}{l}\text { Proximal } \\
\text { Fragment }\end{array}$ & None \\
\hline 41.3 & Chert & 7.86 & Straight/Distal & Sawing & Medium hard & $\begin{array}{l}\text { Secondary } \\
\text { Flake }\end{array}$ & Complete & None \\
\hline 49.1 & Chert & 8.52 & Straight/Lateral & Cutting & Soft & $\begin{array}{l}\text { Secondary } \\
\text { Flake }\end{array}$ & Complete & Intentional \\
\hline
\end{tabular}

Utilized Flakes: A total of seven pieces of lithic debitage exhibit wear indicative of utilization. Utilized flakes account for approximately 32 percent of the tool assemblage. The basic attributes of these materials are recorded in Table 19. Based upon wear patterns observed, it is suggested that these expedient tools were utilized for the activities of cutting, perforating, and planing. Cutting was the predominant activity 
observed, accounting for over 71 percent. Two specimens show wear indicative of use as multipurpose tools.

Table 19: Utilized Flake Attributes

\begin{tabular}{|c|c|c|c|c|c|c|c|c|}
\hline $\begin{array}{l}\text { Cat. } \\
\text { No. }\end{array}$ & Material & $\begin{array}{l}\text { Utilized } \\
\text { Edge } \\
(\mathrm{mm})\end{array}$ & $\begin{array}{l}\text { Utilized Edge } \\
\text { Shape/Location }\end{array}$ & Utilization & Use Material & $\begin{array}{l}\text { Reduction } \\
\text { Type }\end{array}$ & Form & $\begin{array}{l}\text { Thermal } \\
\text { Alteration }\end{array}$ \\
\hline 10.1 & Chert & 3.87 & Straight/Distal & Cutting & Soft & $\begin{array}{l}\text { Tertiary } \\
\text { Flake }\end{array}$ & Complete & None \\
\hline 22.3 & Chert & 11.71 & Straight/Lateral & Cutting & Medium soft & $\begin{array}{l}\text { Tertiary } \\
\text { Flake }\end{array}$ & $\begin{array}{l}\text { Distal } \\
\text { Fragment }\end{array}$ & Unintentional \\
\hline 23.3 & Chert & 11.24 & Recurved/Lateral & Planing & Medium hard & $\begin{array}{l}\text { Secondary } \\
\text { Flake }\end{array}$ & $\begin{array}{l}\text { Proximal } \\
\text { Fragment }\end{array}$ & Intentional \\
\hline 23.4 & Chert & 9.24 & Convex/Distal & Cutting & Medium soft & $\begin{array}{l}\text { Tertiary } \\
\text { Flake }\end{array}$ & Complete & None \\
\hline 35.1 & Chert & 5.37 & $\begin{array}{l}\text { Straight to } \\
\text { Beaked/Lateral }\end{array}$ & $\begin{array}{l}\text { Cutting and } \\
\text { Perforating }\end{array}$ & Medium soft & $\begin{array}{l}\text { Secondary } \\
\text { Flake }\end{array}$ & Complete & None \\
\hline 35.2 & Chert & 5.34 & Concave/Lateral & Planing & Medium soft & $\begin{array}{l}\text { Tertiary } \\
\text { Flake }\end{array}$ & $\begin{array}{l}\text { Medial } \\
\text { Fragment }\end{array}$ & Intentional \\
\hline 48.1 & Chert & 4.36 & Beaked/Lateral & $\begin{array}{l}\text { Cutting and } \\
\text { Perforating }\end{array}$ & $\begin{array}{l}\text { Soft to } \\
\text { medium soft }\end{array}$ & $\begin{array}{l}\text { Tertiary } \\
\text { Flake }\end{array}$ & $\begin{array}{l}\text { Medial } \\
\text { Fragment }\end{array}$ & None \\
\hline
\end{tabular}

\section{Nontool Analysis}

A total of 503 lithic artifacts recovered at 41LE326 have been identified as nontools. These materials are further divided into core $(n=6)$ and unmodified debitage $(n=497)$. Raw material types encountered for nontools include chert $(n=498)$, hematitic sandstone $(n=1)$, macrocrystalline quartz $(n=2)$, and metaquartzite $(n=2)$.

The collection of lithic cores is further identified by reduction type. Five specimens exhibit reduction in a unidirectional manner, and only one exhibits multidirectional reduction.

A total of 497 pieces of unmodified lithic debitage were recovered at the site. Reduction forms and frequency encountered include the following: primary flake ( $n=26,5$ percent), secondary flake $(n=158$, 32 percent), tertiary flake ( $n=309,62$ percent), and chip $(n=4,1$ percent).

\section{Thermally Altered Rock Analysis}

Lithic materials classified as thermally altered rocks exhibit characteristics typically associated with exposure to heat. These signs include color change, increased luster, and/or fracturing.

Lithic materials judged to be thermally altered were further subcategorized as either burned rock or firecracked rock. Burned rock specimens exhibit increased luster and/or color change associated with heat alteration but do not exhibit heat fracturing. Fire-cracked rock specimens exhibit all three forms of heat alteration including color change, increased luster, and heat fracturing. 
A total of 239 pieces of thermally altered rock were recovered at 41LE326. Only two specimens were identified as burned rocks, with the remainder of the collection being identified as fire-cracked rocks. Within the fire-cracked rock specimens, an additional 213 were further identified as shatter, and 17 were further identified as pot lids. Material types encountered include chert $(n=236,98.8$ percent), hematitic sandstone ( $n=2,0.8$ percent), and silicified wood ( $n=1,0.4$ percent). 



\section{CONCLUSIONS AND RECOMMENDATIONS}

Subsurface investigations at 41LE326 failed to encounter any evidence that intact prehistoric cultural deposits or features exist within the TxDOT right of way. Observation of the subsurface depth of modern materials, including a metal fence staple and glass shard between 40 and $50 \mathrm{cmbs}$, provides evidence of the effects of bioturbation in this portion of the site, which further offers strong evidence for the presence of disturbance that contributes to a lack of archeological integrity. Based on stratigraphic data, lack of intact features, and low subsurface artifact density, it appears that the investigated portion of the site lacks integrity, and it is unlikely that additional archeological investigations within this portion of 41LE326 would contribute to our understanding of the area's prehistory. Therefore, the portion of 41LE326 within the project APE consisting of the existing right of way does not contribute to the site's eligibility for listing in the NRHP and does not warrant designation as a SAL. No further work is recommended. Final curation of all collected materials will occur at the Texas Archeological Research Laboratory in consultation with TxDOT ENV. 



\section{REFERENCES CITED}

Bell, R.E.

1960 Guide to the Identification of Certain American Indian Projectile Points. Special Bulletin No. 2 of the Oklahoma Anthropological Society. December 1960.

Blair, W.F.

1950 The Biotic Provinces of Texas. Texas Journal of Science 2:93-117.

Bryant, V.M. Jr.

1977 A 16,000 Year Pollen Record of Vegetational Change in Central Texas. Palynology 1:143-157.

Bureau of Economic Geology

1974 Geologic Atlas of Texas, Austin Sheet. Bureau of Economic Geology, University of Texas at Austin.

Campbell, T.N.

1983 Espinosa, Olivares, and the Colorado River Indians, 1709. Sayersville Historical Association Bulletin 3:2-6, 15-16

1986 Name All the Indians of the Bastrop Area. Sayersville Historical Association Bulletin 7:7-10.

Camper, H.A.C.

1991 Pollen Analysis of Patschke Bog. Unpublished Master’s thesis, Texas A\&M University, College Station.

Collins, M.B.

1998 Background to the Archeological Investigations. In Wilson-Leonard An 11,000-Year Archeological Record of Hunter-Gatherers in Central Texas, Vol. 1, edited and compiled by Michael B. Collins, pp. 55-67. Studies in Archeology 31, Texas Archeological Research Laboratory, The University of Texas at Austin, and Archeology Studies Program Report 10, Texas Department of Transportation, Environmental Affairs Division, Austin.

2004 Archeology of Central Texas. In The Prehistory of Texas, edited by T. K. Perttula, pp. 101-126. Texas A\&M University Press, College Station.

Ellis, L.W., K.M. McDonald, and M.A. Nash

2009 Report of Surveys and Impact Evaluation Conducted in TxDOT's Austin, Bryan, and Yoakum Districts during 2006-2008 under Contract No. 57LXX5A005. Archeological Studies Program Report No. 115. Texas Department of Transportation, Austin.

Foster, W.C.

1995 Spanish Expeditions into Texas, 1689-1768. University of Texas Press, Austin. 
Frederick, C.D., and C. Ringstaff

1994 Lithic Resources at Fort Hood: Further Investigation. Archeological Investigations on 571 Prehistoric Sites at Fort Hood, Bell, and Coryell Counties, Texas. United States Army, Fort Hood Archeological Resource Management Series, Research Report No. 31.

Hall, S.A.

1990 Channel Trenching and Climatic Change in the Southern U.S. Great Plains. Geology 18:342-345.

Hatch, S.L., N.G. Kancheepuram, and L.E. Brown

1990 Checklist of the Vascular Plants of Texas. MP-1655. Texas Agricultural Experiment Station, College Station, Texas.

Jelks, E.B.

1962 The Kyle Site: A Stratified Central Texas Aspect Site in Hill County, Texas. Department of Anthropology Archaeology Series 5. The University of Texas at Austin.

Johnson, L. Jr.

1989 Great Plains Interlopers in the Eastern Woodlands during Paleo-Indian Times. Office of the State Archeologist Report 36. Texas Historical Commission, Austin.

1994a The Life and Times of Toyah-Culture Folk As Seen From the Buckhollow Encampment, Site 41KM16, of Kimble County, Texas. Office of the State Archeologist Report Series, No. 38. Texas Department of Transportation and Texas Historical Commission.

1994b A New Try at Dating and Characterizing Holocene Climates, as Well as Archeological Periods on the Eastern Edwards Plateau. Bulletin of the Texas Archeological Society 65:1-51.

Johnson, L. Jr., and T.N. Campbell

1992 Sanan: Traces of a Previously Unknown Aboriginal Language in Colonial Coahuila and Texas. Plains Anthropologist 37:185-212.

Johnson, L. Jr., and G. Goode

1994 A New Try at Dating and Characterizing Holocene Climates, as Well as Archeological Periods, on the Eastern Edwards Plateau. Bulletin of the Texas Archeological Society 65:1-51.

Keeley, L.H.

1980 Experimental Determination of Stone Tool Uses: A Microwear Analysis. The University of Chicago Press, Chicago and London.

McGraw, A.J., and S.L. Hardin

1998 The Evolution of the Old San Antonio Road and the Caminos Reales. In A Texas Legacy: The Old San Antonio Road and the Caminos Reales, a Tricentennial History, 1691-1991, edited by A. Joachim McGraw, John W. Clark, Jr., and Elizabeth A. Robbins, pp. 229234. Texas Department of Transportation, Austin. 
Natural Resources Conservation Service

1989 Web Soil Survey. Natural Resources Conservation Service, United States Department of Agriculture. http://websoilsurvey.nrcs.usda.gov (accessed 27 September 2006)

Nesse, W.D.

2000 Introduction to Mineralogy. Oxford University Press, New York, Oxford.

Nichols, M.

2006 Interim Report for Archaeological Survey. Performed in compliance with Texas Antiquities Permit Number 4239. PBS\&J, Austin, Texas

Nordt, L.C.

1992 Archeological Geology of the Fort Hood Military Reservation, Fort Hood, Texas. Archeological Resource Management Series, Research Report No. 29. United States Army, Fort Hood, Texas.

1993 Additional Geoarcheological Investigations at the Fort Hood Military Reservation, Fort Hood, Texas. Archeological Resource Management Series, Research Report No. 29. United States Army, Fort Hood, Texas.

Potzger, J.E., and B.C. Tharp

1947 Pollen Profile from a Texas Bog. Ecology 28:274-280.

1954 Pollen Studies of Two Bogs in Texas. Ecology 35:462-466.

Prewitt, E.R.

1981 Cultural Chronology in Central Texas. Bulletin of the Texas Archeological Society 5:65-89.

1982 Archeological Investigations at the Loeve-Fox, Loeve, and Tombstone Bluff Sites in the Granger Lake District of Central Texas. Institute of Applied Sciences, University of North Texas, Denton.

1985 From Circleville to Toyah: Comments on Central Texas Chronology. Bulletin of the Texas Archeological Society 54:201-238.

Purdy, B.A., and H.K. Brooks

1971 Thermal Alteration of Silica Minerals: An Archeological Approach. Science 173:322325.

Radian Corporation

1976 Six Month Progress Report: Environmental Assessment of a Proposed Lignite Surface Mine near Rockdale, Texas. Vols. I-A and I-B, main report. On file, Texas Historical Commission, Austin.

Rice, P.M.

1987 Pottery Analysis: A Sourcebook. University of Chicago Press, Chicago. 
Robbins, E.A.

1998 Appendix 1: Itineraries of Selected Journeys Across Texas. In A Texas Legacy: The Old San Antonio Road and the Caminos Reales, a Tricentennial History, 1691-1991, edited by A. Joachim McGraw, John W. Clark, Jr., and Elizabeth A. Robbins, pp. 353-368. Texas Department of Transportation, Austin.

Rogers, A.F.

1928 Natural History of the Silica Minerals. American Mineralogist 13:73-92.

Rogers, R.

1999 Excavations at the Walleye Creek Site (41LE57), Lee County, Texas. Document No. 981670. Espey, Huston \& Associates, Inc., Austin.

Rogers, R., and E. Foster

1994 National Register Assessment of Three Archaeological Sites at the Gibbons Creek Lignite Mine, Grimes County, Texas. Document No. 940325. PBS\&J, Austin.

Rogers, R., and S. Kotter

1995 Excavations at the Chesser Site (41LE59), Lee County, Texas. Document No. 950209. Espey, Huston \& Associates, Inc., Austin.

Schmidly, D.J.

1983 Texas Mammals East of the Balcones Fault Zone. Texas A\&M University Press, College Station.

Soil Survey Staff

1975 Soil Taxonomy. Agriculture Handbook No. 436. Soil Conservation Service, United States Department of Agriculture, Washington, D.C.

2007 Natural Resources Conservation Service, United States Department of Agriculture. Official Soil Series Descriptions. http://soils.usda.gov/technical/classification/osd/index. html (accessed 28 March 2007).

Texas Ornithological Society

1984 Checklist of the Birds of Texas. 2nd edition. Texas Ornithological Society.

Toomey, R.S., III

1993 Late Pleistocene and Holocene Faunal Changes at Hall's Cave, Kerr County, Texas. Unpublished Ph.D. dissertation, Department of Geology, The University of Texas at Austin.

Turner, E.S., and T.R. Hester

1999 A Field Guide to Stone Artifacts of Texas Indians. 2nd ed. Gulf Publishing Company, Houston, Texas.

Weddle, R. S.

2010 Handbook of Texas Online, s.v. "Rancheria Grande," http://www.tshaonline.org/ handbook/online/articles/RR/bpr1.html (accessed August 19, 2010). 
Appendix A

\author{
Site Location Map \\ (Not for Public Disclosure)
}





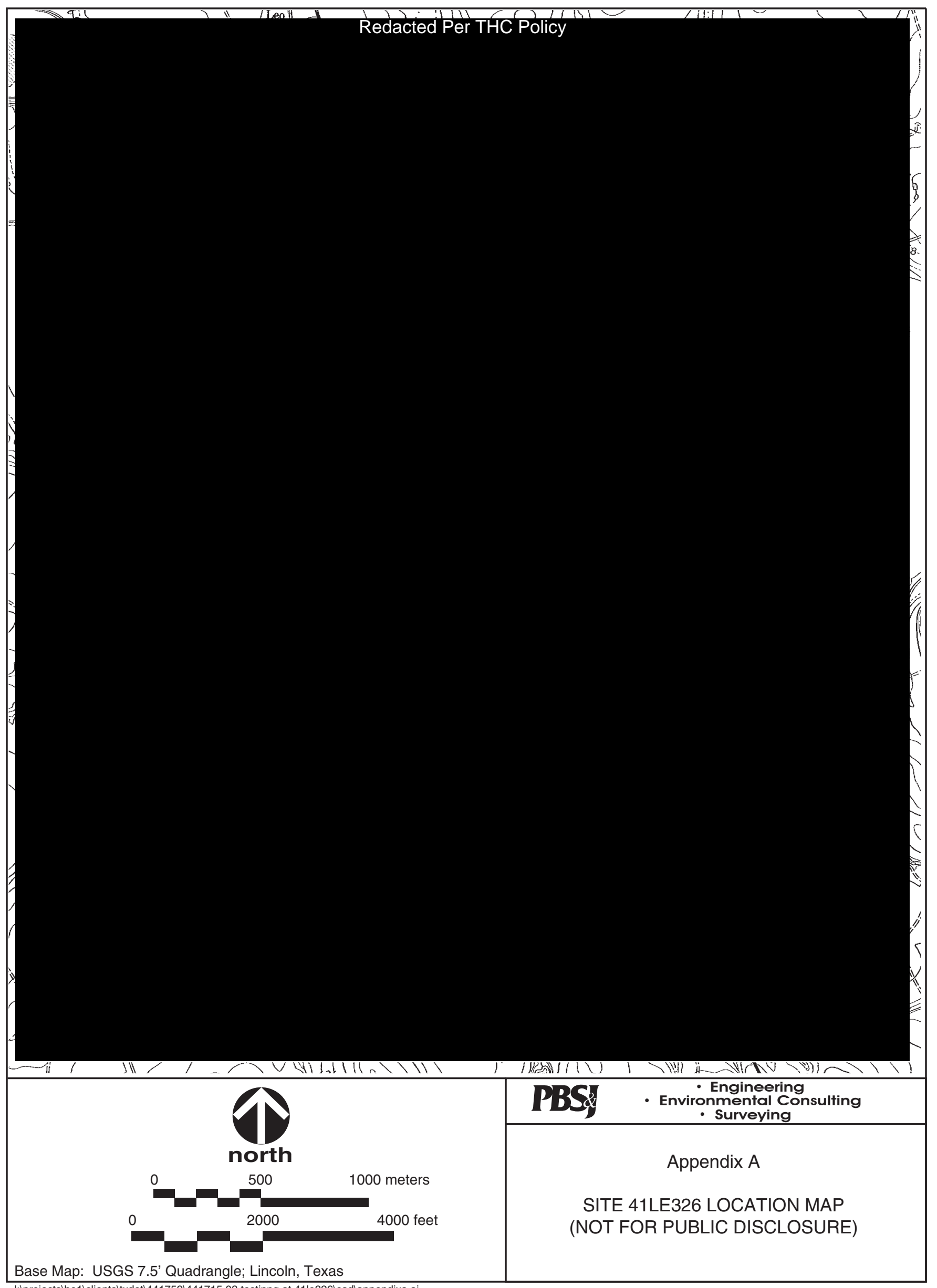

I:Iprojects|he1/clients|txdot|441759|441715.03 testinng at 41le326lcadlappendixa.ai 

Appendix B

Specimen Inventory 

Appendix B: Specimen Inventory

\begin{tabular}{|c|c|c|c|c|c|c|c|c|c|c|c|c|c|c|}
\hline \multirow[b]{2}{*}{ Trinomial } & \multirow[b]{2}{*}{ Lot No. } & \multirow[b]{2}{*}{ FS No. } & \multirow[b]{2}{*}{ ST No. } & \multirow{2}{*}{$\begin{array}{l}\text { Test } \\
\text { Unit }\end{array}$} & \multirow[b]{2}{*}{ Level } & \multicolumn{2}{|c|}{ Depth } & \multicolumn{2}{|c|}{ Prehistoric } & \multirow{2}{*}{$\begin{array}{c}\text { Historic } \\
\text { Glass }\end{array}$} & \multirow{2}{*}{$\begin{array}{l}\text { Charcoal } \\
\text { (g) }\end{array}$} & \multirow{2}{*}{$\begin{array}{l}\text { Thermally } \\
\text { Altered Rock }\end{array}$} & \multirow{2}{*}{$\begin{array}{l}\text { Burned } \\
\text { Clay }\end{array}$} & \multirow[b]{2}{*}{ Comments } \\
\hline & & & & & & (cmbs) & (cmbd) & Lithic & Ceramic & & & & & \\
\hline 41LE326 & 1 & 2 & 1 & & 1 & $0-50$ & & 1 & & & & 1 & & \\
\hline 41LE326 & 2 & 1 & 1 & & 2 & $50-60$ & & 6 & & & & 3 & & \\
\hline 41LE326 & 3 & 8 & 2 & & 2 & $10-20$ & & 3 & & & & 2 & & \\
\hline 41LE326 & 4 & 4 & 2 & & 3 & $20-30$ & & 1 & & & & 2 & & \\
\hline 41LE326 & 5 & 5 & 2 & & 4 & $30-40$ & & 1 & & & & & & \\
\hline 41LE326 & 6 & 16 & 3 & & 2 & $10-20$ & & 6 & & & & & & \\
\hline 41LE326 & 7 & 17 & 3 & & 3 & $20-30$ & & 1 & & & & 2 & & \\
\hline 41LE326 & 8 & 18 & 3 & & 6 & $50-60$ & & & & & & 1 & & \\
\hline 41LE326 & 9 & 21 & 3 & & 8 & $70-80$ & & 1 & & & & 2 & & \\
\hline 41LE326 & 10 & 6 & 4 & & 1 & $0-10$ & & 3 & & & & 2 & & \\
\hline 41LE326 & 11 & 14 & 5 & & 1 & $0-10$ & & 4 & & & & 2 & & \\
\hline 41LE326 & 12 & 9 & 8 & & 1 & $0-10$ & & 2 & & & & & & \\
\hline 41LE326 & 13 & 10 & 8 & & 2 & $10-20$ & & 2 & & & & & & \\
\hline 41LE326 & 14 & 11 & 8 & & 3 & $20-30$ & & 4 & & & & 3 & & \\
\hline 41LE326 & 15 & 7 & 8 & & 4 & $30-40$ & & 1 & & & & & & \\
\hline 41LE326 & 16 & 12 & 8 & & 5 & $40-50$ & & 6 & & & & & & \\
\hline 41LE326 & 17 & 13 & 8 & & 6 & $50-60$ & & 2 & & & & 2 & & \\
\hline 41LE326 & 18 & 22 & 9 & & 3 & $20-30$ & & 1 & & & & & & \\
\hline 41LE326 & 19 & 23 & 9 & & 4 & $30-40$ & & 2 & & & & & & \\
\hline 41LE326 & 20 & 3 & & 1 & 1 & $0-10$ & $23-33$ & 29 & & & & 29 & & \\
\hline 41LE326 & 21 & 15 & & 1 & 2 & $10-20$ & 33-43 & 33 & & & & 9 & & \\
\hline 41LE326 & 22 & 19 & & 1 & 3 & $20-30$ & $43-53$ & 64 & & & & 27 & & \\
\hline 41LE326 & 23 & 24 & & 1 & 4 & $30-40$ & $53-63$ & 66 & & & & 37 & & \\
\hline 41LE326 & 24 & 25 & & 1 & 5 & $40-50$ & $63-73$ & 9 & & & & 8 & & \\
\hline 41LE326 & 25 & 26 & & 1 & 6 & $50-60$ & $73-83$ & 7 & & & & 1 & & \\
\hline 41LE326 & 26 & 27 & & 2 & 1 & $0-10$ & $20-30$ & 4 & & & & & & \\
\hline 41LE326 & 27 & 28 & & 2 & 2 & $10-20$ & $30-40$ & 5 & & & & & & \\
\hline 41LE326 & 28 & 29 & & 2 & 3 & $20-30$ & $40-50$ & 7 & & & & & & \\
\hline 41LE326 & 29 & 30 & & 2 & 4 & $30-40$ & $50-60$ & 2 & & 1 & & & 1 & \\
\hline 41LE326 & & & & 2 & 4 & 40 & 60 & & & & & & & $\begin{array}{l}1 \text { modern glass shard observed but not } \\
\text { collected }\end{array}$ \\
\hline 41LE326 & 30 & 31 & & 2 & 5 & $40-50$ & $60-70$ & & & & & & 1 & Burned clay found at bottom of level \\
\hline 41LE326 & 31 & 32 & & 3 & 1 & $0-10$ & $10-20$ & 14 & & & & 3 & & \\
\hline 41LE326 & 32 & 33 & & 3 & 2 & $10-20$ & $20-30$ & 16 & & & 0.40 & 6 & & \\
\hline 41LE326 & 33 & 34 & & 3 & 3 & $20-30$ & $30-40$ & 6 & & & & 2 & & \\
\hline 41LE326 & 34 & 35 & & 3 & 4 & $30-40$ & $40-50$ & 13 & & & & 9 & & \\
\hline 41LE326 & 35 & 36 & & 3 & 5 & $40-50$ & $50-60$ & 18 & & & & 9 & & \\
\hline 41LE326 & & & & 3 & 5 & 50 & 60 & & & & & & & $\begin{array}{l}1 \text { modern metal fence staple observed but } \\
\text { not collected }\end{array}$ \\
\hline
\end{tabular}


Appendix B: Specimen Inventory

\begin{tabular}{|c|c|c|c|c|c|c|c|c|c|c|c|c|c|c|}
\hline \multirow[b]{2}{*}{ Trinomial } & \multirow[b]{2}{*}{ Lot No. } & \multirow[b]{2}{*}{ FS No. } & \multirow[b]{2}{*}{ ST No. } & \multirow{2}{*}{$\begin{array}{l}\text { Test } \\
\text { Unit }\end{array}$} & \multirow[b]{2}{*}{ Level } & \multicolumn{2}{|c|}{ Depth } & \multicolumn{2}{|c|}{ Prehistoric } & \multirow{2}{*}{$\frac{\text { Historic }}{\text { Glass }}$} & \multirow{2}{*}{$\begin{array}{l}\text { Charcoal } \\
\text { (g) }\end{array}$} & \multirow{2}{*}{$\begin{array}{c}\text { Thermally } \\
\text { Altered Rock }\end{array}$} & \multirow{2}{*}{$\begin{array}{c}\text { Burned } \\
\text { Clay }\end{array}$} & \multirow[b]{2}{*}{ Comments } \\
\hline & & & & & & (cmbs) & $(\mathrm{cmbd})$ & Lithic & Ceramic & & & & & \\
\hline 41LE326 & 36 & 37 & & 3 & 6 & $50-60$ & $60-70$ & 12 & & & & 5 & & \\
\hline 41LE326 & 37 & 38 & & 3 & 7 & $60-70$ & $70-80$ & 18 & & & & 8 & & \\
\hline 41LE326 & 38 & 39 & & 3 & 8 & $70-80$ & $80-90$ & 19 & & & & 4 & & \\
\hline 41LE326 & 39 & 40 & & 3 & 9 & $80-90$ & $90-100$ & 22 & & & & 12 & & \\
\hline 41LE326 & 40 & 41 & & 3 & 9 & $80-90$ & $90-100$ & 11 & & 1 & & 3 & & From Gopher hole fill \\
\hline 41LE326 & 41 & 42 & & 3 & 10 & $90-100$ & $100-110$ & 45 & & & & 19 & & \\
\hline 41LE326 & 42 & 43 & & 3 & 11 & $100-110$ & $110-120$ & 12 & & & & 7 & & \\
\hline 41LE326 & 43 & 44 & & 4 & 1 & $0-10$ & $20-30$ & 7 & & & & 1 & & \\
\hline 41LE326 & 44 & 45 & & 4 & 2 & $10-20$ & $30-40$ & 9 & & & & 2 & & \\
\hline 41LE326 & 45 & 46 & & 4 & 3 & $20-30$ & $40-50$ & 9 & & & & 4 & & \\
\hline 41LE326 & 46 & 47 & & 4 & 4 & $30-40$ & $50-60$ & 14 & & & & 3 & & \\
\hline 41LE326 & 47 & 48 & & 4 & 5 & $40-50$ & $60-70$ & 4 & & & & 5 & 1 & \\
\hline 41LE326 & 48 & 49 & & 4 & 6 & $50-55$ & $70-75$ & 1 & & & & 2 & & \\
\hline 41LE326 & 49 & 20 & 3 & & 7 & $60-70$ & & 2 & & & & 2 & & \\
\hline Total: & & & & & & & & 525 & 0 & 2 & 0.40 & 239 & 3 & \\
\hline
\end{tabular}


Appendix C

THC Concurrence 



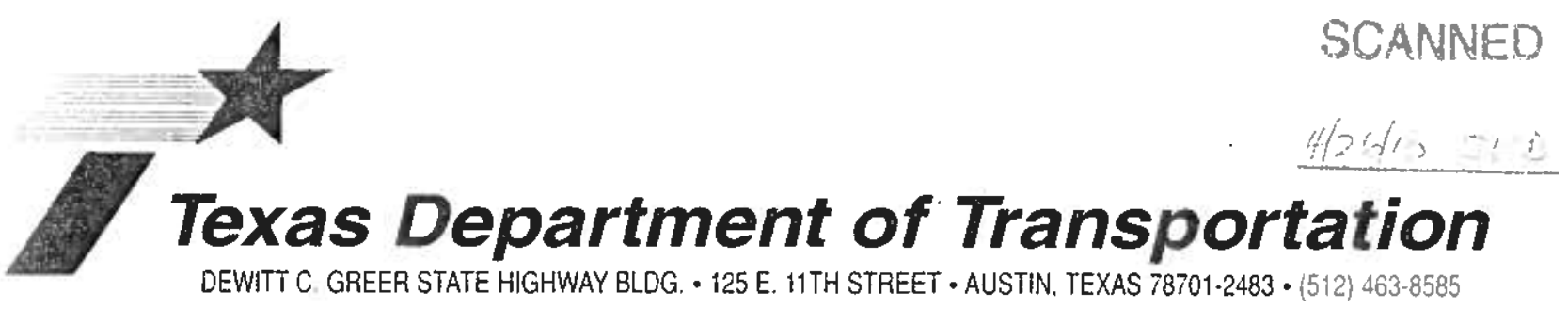

April 12, 2010

RE: Transmittal of the PBS\&J Report of NRHP Testing of 41 LE326 in Lee County: Austin District: CSJ: 0211-03-032: TA Permit No. 4439

James E. Bruseth, Ph.D.

Division of Archeology, Texas Historical Commission

P.O. Box 12276

Austin, Texas $787\lfloor 1$

Dear Dr. Bruseth:

In accord with the Memorandum of Understanding (MOU) between TxDOT and THC, we are continuing Antiquities Code of Texas consultation for the proposed undertakings. The THC previously issued Texas Antiquities Permit No. 4439 to PBS\&J to conduct National Register of Historic Places (NRHP) eligibility testing for the prehistoric archeological site recorded as 41 LE326. This investigation was conducted in support of the roadway improvements for US 77 in Lee County: CSJ: 0211-03-032. On May 10, 2007, the THC concurred that 41 LE326 is not eligible for listing on the NRHP, that the inventory is complete, and for a finding of "no historic properties affected.

PBS\&J has recently submitted a copy of their draft final repott entitled, "National Register of Historic Places Eligibility Testing of Site 4l LE326, Lee County, Texas". The Section 106 consultation for this project has been previously conducted with the THC via an interim report (see attached THC consultation letter dated May 8, 2007). This correspondence addresses the reporting requirement of the Antiquities Code. TxDOT has reviewed this draft report and found it acceptable. A copy of the draft final report is attached for your revicw.

TxDOT seeks THC concurrence that the report is sufficient and that the stipulations set forth in the Antiquities Code are fulfilled. Please signify your concurrence by signing on the line provided below. Thank you for your consideration in this matter. If you have any questions, please contact me at (512) 416-2640.

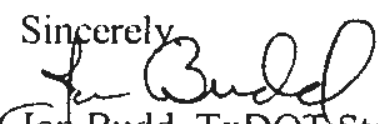

Jon Budd, TxDOT Staff Archeologist

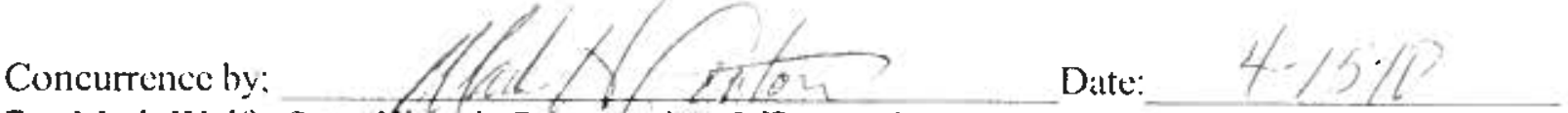

For Mark Wolfc, Statu Historic Preservation Officer and Exccutive Director Attachments

cc w/o attachments: Austin District, ATTN: M. Walker. ENV-VC. IHB 


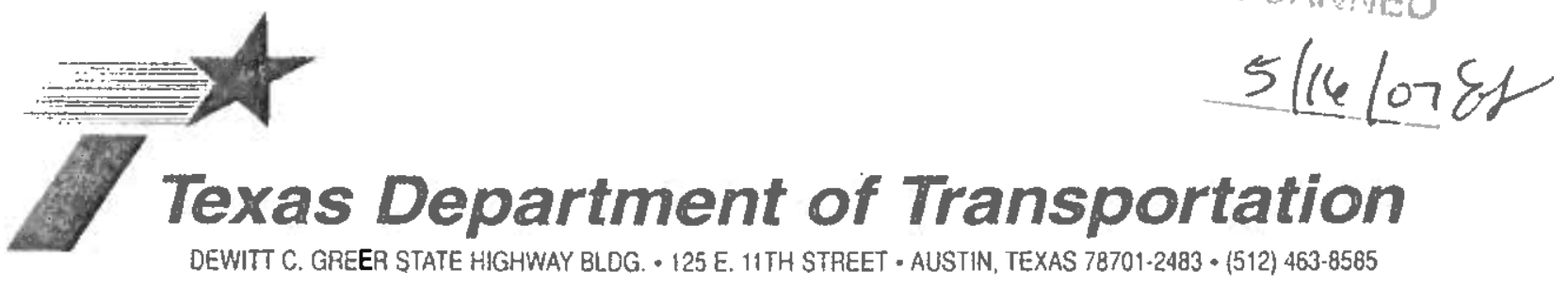

May 8. 2007

RE: Transmittal of TxDOT Recommendations for "No Historic Properties Affected" for the US 77 at Middle Yegua Creek Bridge Replacement Project in Lee County: CSJ: 021 1-03-032: PBS\&J Draft Interim Report of NRHP Eligibility Testing of Site 41LE326, Lee County, Texas.

Texas Antiquities Permit No.: 4439

James E. Bruseth, Ph.D.

Division of Archeology, Texas Historical Commission

P.O. Box 12276

Austin, Texas 78711

Dear Dr. Bruseth:

In accord with the First Amended Programmatic Agreement among TxDOT, the Federal Highways Administration, the Texas State Historical Preservation Officer (THC), and the Advisory Council on Historic Preservation regarding the Implementation of Transportation Activities (PA), and the Memorandum of Understanding (MOU) between TxDOT and THC, we are initiating Section 106 and Antiquities Code consultation for this proposed undertaking.

This undertaking entails replacing the existing 600 by 47 foot bridge with a new 640 by 70 foot structure on US 77at Middle Yegua Creek located south of the community of Lexington in Lee County, Texas. The approaches would be reworked to match the proposed structure. All work would be limited to the existing 200 foot wide right-of-way. No new right-of-way would be required. TxDOT recommended that an intensive archeological survey be conducted within the undertaking's area of potential effect (APE).

In October of 2006, staff from PBS\&J conducted the prescribed archeological survey within the APE under their Statewide Survey Texas Antiquities Permit No. 4239. One prehistoric archeological site was identified and recorded as 41LE326. Besides 41LE326, PBS\&J did not observe any other archeological remains within the APE. They recommended National Register of Historic Places (NRHP) eligibility testing for 41LE326. They also recommended that no further archeological work is required for the remainder of the APE located outside of the 41LE326 site boundaries. TXDOT agreed with the PBS\&J recommendations. A copy of the interim survey report is attached for your review.

Staff from your office assigned Texas Antiquities Permit No. 4439 to PBS\&J to conduct the prescribed NRHP eligibility testing for 4LLE326. PBS\&J has recently concluded the field work and interim reporting for that investigation. The investigation included a total of four 1 by 1 meter hand excavated units, 9 backhoe trenches, two mechanically scraped areas, and 9 additional shovel tests. One Perdiz arrow point was collected from Test Unit (TU) \#4 from 20 to 30 centimeters below the current ground surface (cmbs). One unspecified dart point fragment was recovered from Shovel Test \#5 from 0 to $10 \mathrm{cmbs}$. One possible Pedernales dart base fragment was collected in TU \#3 at 90 to $110 \mathrm{cmbs}$. A total of 794 prehistoric artifacts were collected. No undisturbed features or faunal remains were observed. In addition, modern glass was recovered in $T U \# 2$ at $40 \mathrm{~cm}$ below ground surface and one metal fence staple observed $50 \mathrm{~cm}$ subsurface in $\mathrm{TU} \# 3$. The investigators 
RE: Transmittal of TxDOT Recommendations for "No Historic Properties Affecled" for the US 77 at Middle Yegua Creek Bridge Replacement Project in Lee County: CSJ: 0211 -03-032: PBS\&J Draft Interim Report of National Register Testing of Site 4ILE326, Lee County, Texas.

Texas Antiquities Permit No.: 4439

have concluded that minimal potential exists for buried intact archeological deposits associated with 41LE326 to exist within the APE. A copy of their draft report is attached for your review.

TxDOT has reviewed the attached PBS\&J NRHP eligibility testing report and agrees with their recommendations. However, this review has identified a number of minor clarification issues in that draft report. These issues and TxDOT's related comments are attached to this letter. TxDOT recommends that PBS\&J address these comments in their final draft report.

Based upon their findings, TXDOT agrees with the PBS\&J recommendations and seeks THC concurrence that the inventory of the undertaking is complete, that the portion of 41LE326 located with the APE does not contribute to the sites NRHP eligibility and does not warrant designation as a State Archeological Landmark. In addition, TxDOT seeks THC concurrence for a finding of "no historic properties affected" for the undertaking and that no further work or THC consultation is required. TxDOT also seeks THC concurrence that the attached TxDOT comments and any comments that the THC may have should be addressed in the final PBS\&J draft final report. Please signify your concurrence by signing on the signature line provided below.

In the event that archeological materials are discovered during construction, construction in the immediate area shall cease, and the State Historic Preservation Officer will be contacted to initiate accidental discovery procedures in accordance of the terms of the Programmatic Agreement among the Texas Historical Commission, the Federal Highway Administration, and the Texas Department of Transportation. If you have any questions, please contact me at 416-2640. Thank you for your consideration in this matter.

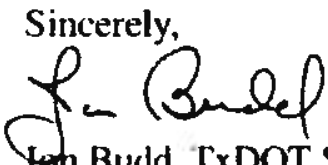

Yoh Budd, TxDOT Staff Archeologist

Concurrence by;

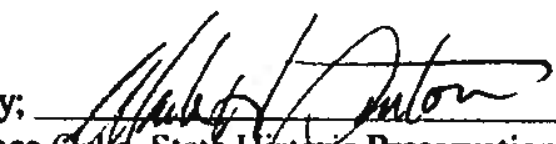

Date:

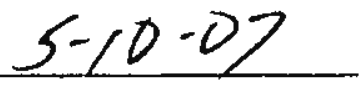

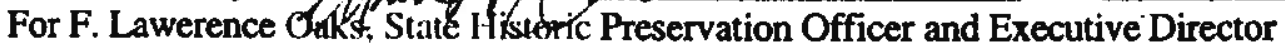

Attachments

c w/attachments: Austin District Office, ATTN: M. Walker, ENV-JAR, JHB, Reading File 